\title{
Endangered Species Management Plan for Fort Hood, Texas; FY01-05
}

Timothy J. Hayden, John D. Cornelius, Howard J. Weinberg,

March 2001

Leslie L. Jette, and Robert H. Melton
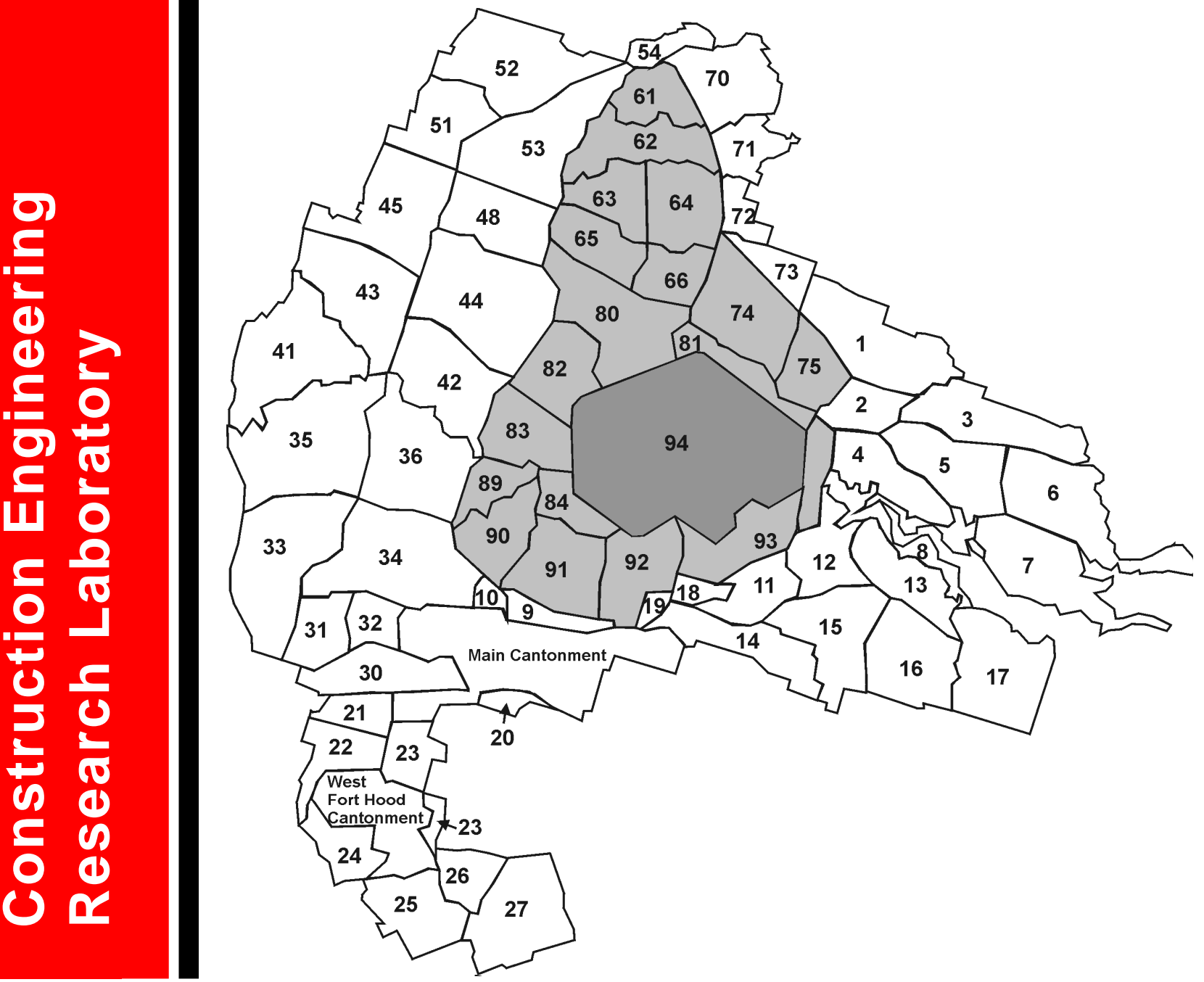


\section{Foreword}

This study was conducted for III Corps and Fort Hood, Natural Resources Branch, under MIPR \#9DCER00242. The technical monitor was J ohn D. Cornelius.

The work was performed by the Ecological Processes Branch (CN-N) of the Installations Division $(\mathrm{CN})$, Construction Engineering Research Laboratory (CERL). The CERL Principal Investigator was Timothy J . Hayden. The technical editor was Gloria J . Wienke, Information Technology Laboratory. Stephen E. Hodapp is Chief, CEERD-CN-N, and Dr. J ohn T. Bandy is Chief, CEERD-CN. The associated Technical Director was Dr. William D. Severinghaus, (CEERDTD). The Acting Director of CERL is William D. Goran.

CERL is an element of the U.S. Army Engineer Research and Development Center (ERDC), U.S. Army Corps of Engineers. The Director of ERDC is Dr. J ames R. Houston and the Commander is COL J ames S. Weller.

\section{DISCLAIMER}

The contents of this report are not to be used for advertising, publication, or promotional purposes. Citation of trade names does not constitute an official endorsement or approval of the use of such commercial products. All product names and trademarks cited are the property of their respective owners.

The findings of this report are not to be construed as an official Department of the Army position unless so designated by other authorized documents.

DESTROY THIS REPORT WHEN IT IS NO LONGER NEEDED. DO NOT RETURN IT TO THE ORIGINATOR. 


\section{Contents}

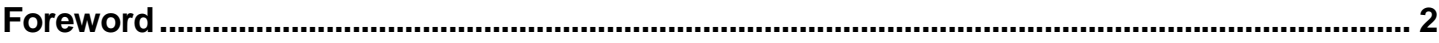

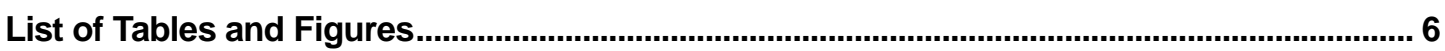

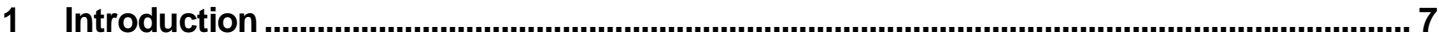

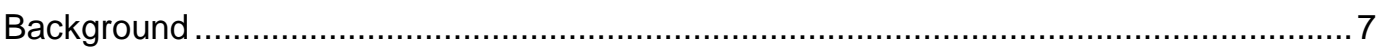

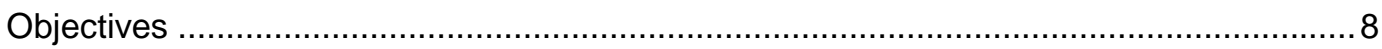

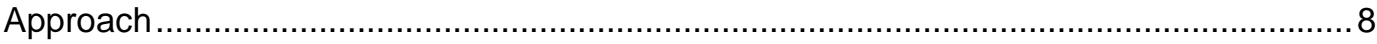

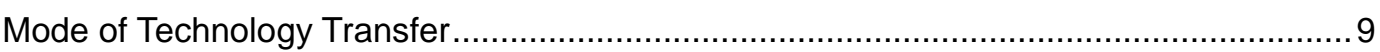

2 Site Description and Land Use Activities...................................................................11

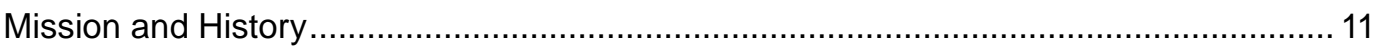

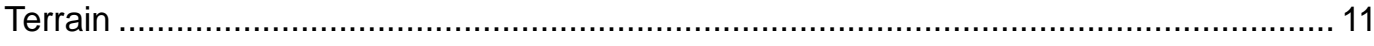

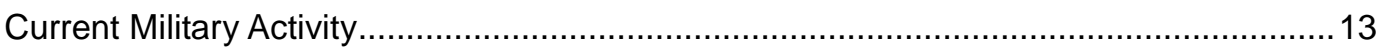

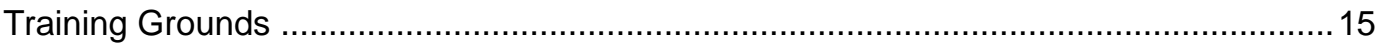

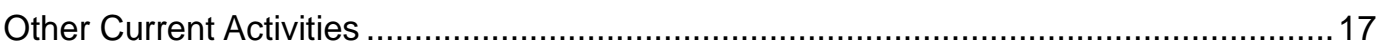

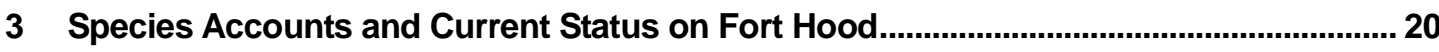

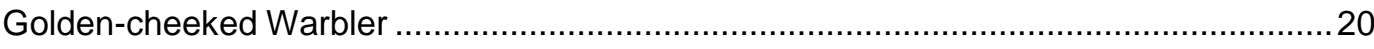

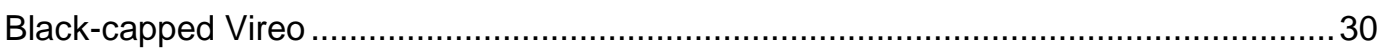

Croton alabamensis (Texabama croton) ………..................................................... 40

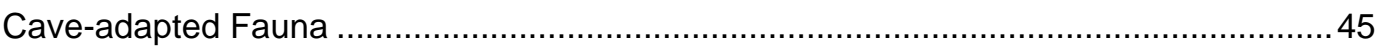

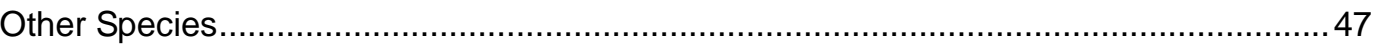

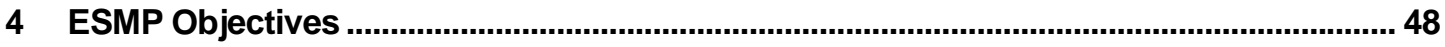

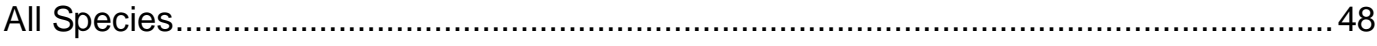

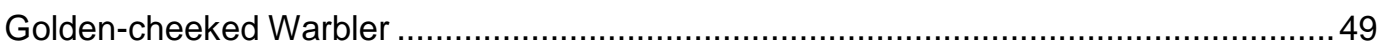

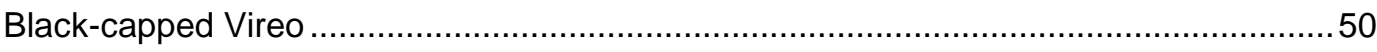

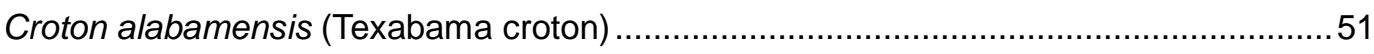

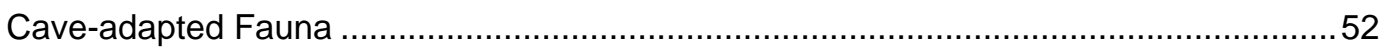

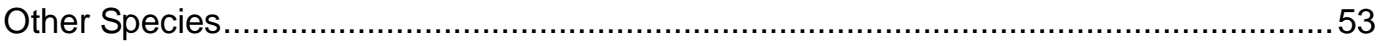

5 Conservation Actions: All Federally Listed Species........................................................ 54

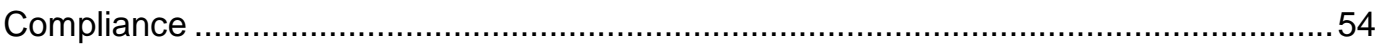

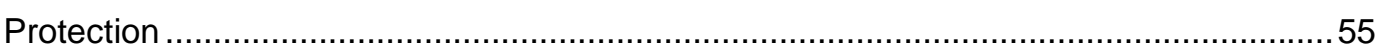


6 Conservation Actions: Golden-cheeked Warbler …........................................................... 57

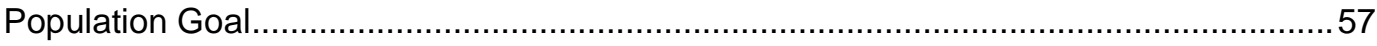

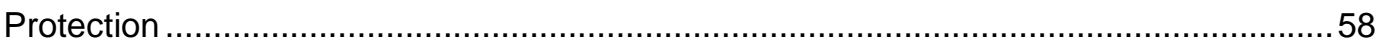

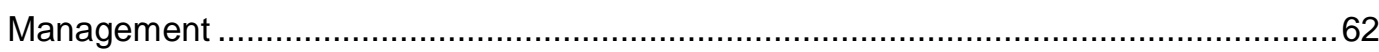

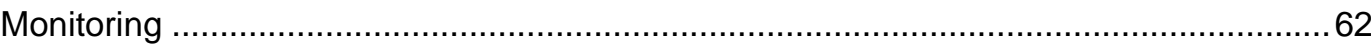

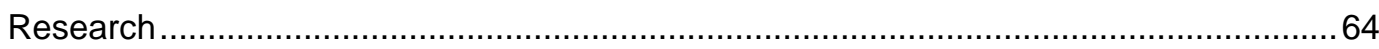

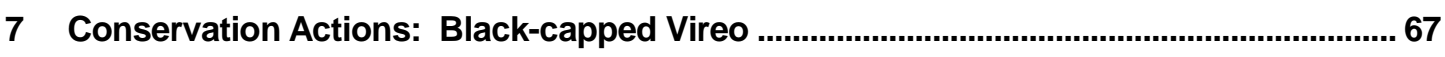

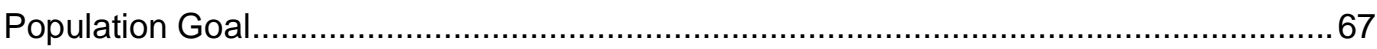

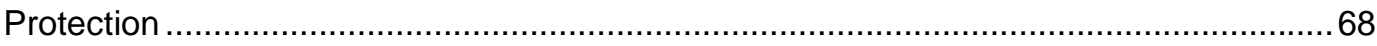

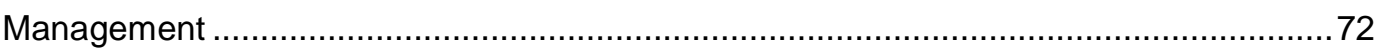

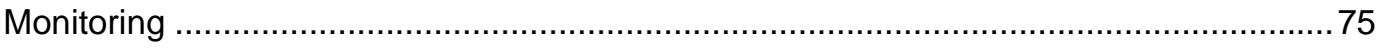

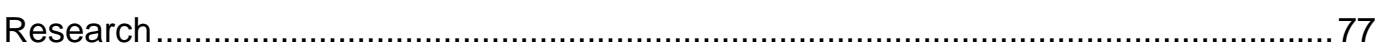

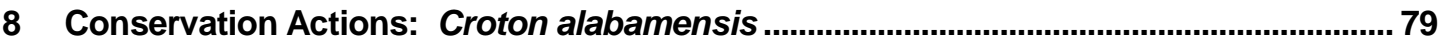

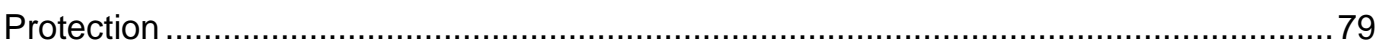

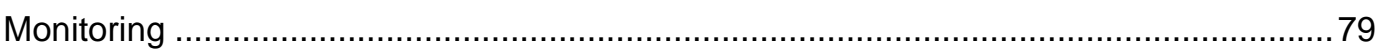

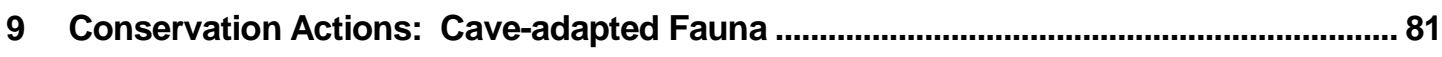

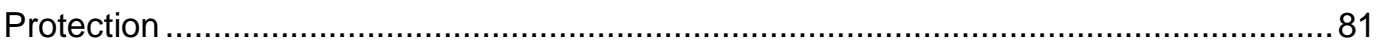

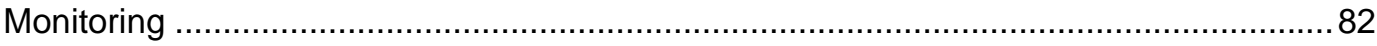

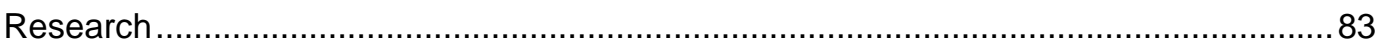

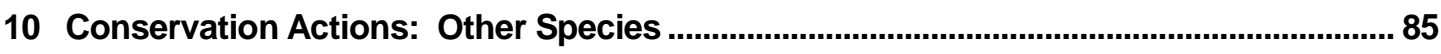

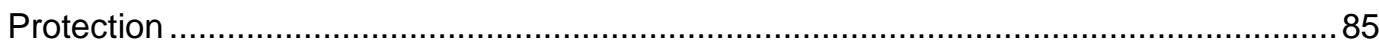

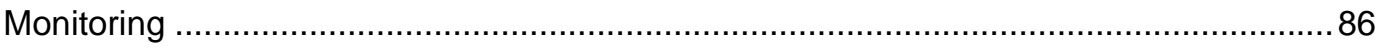

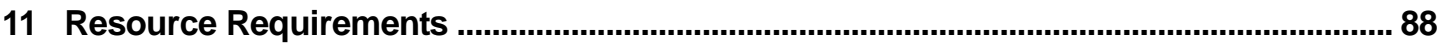

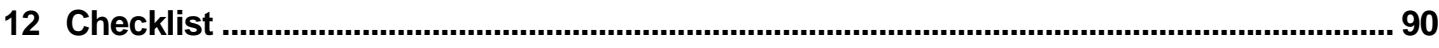

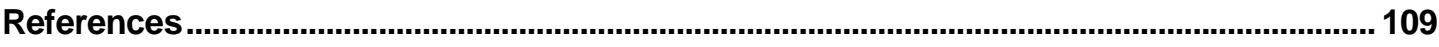

Appendix A: U.S. Fish and Wildlife Service Biological Opinion for Fort Hood,

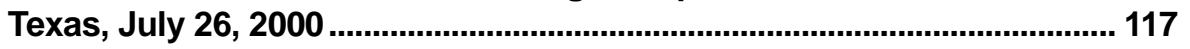

Appendix B: $\quad$ Fort Hood Fire Management and Protection Policies .............................. 138

Appendix C: $\quad$ Fort Hood Endangered Species Training Guidelines .................................. 142

Appendix D: Population Viability Analyses of the Golden-cheeked Warbler and the Black-capped Vireo on Fort Hood, Texas .............................................. 144

Appendix E: “Environmental Assessment" and "Finding of No Significant Impact" for the Fort Hood Endangered Species Management Plan ......... 151 


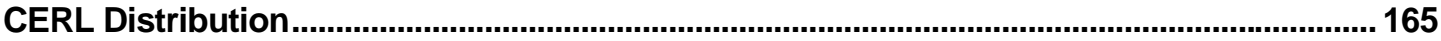

Report Documentation Page ..................................................................................................... 166 


\section{List of Tables and Figures}

\section{Tables}

1 Federal endangered, threatened, and candidate species that occur or may occur on Fort Hood.

2 Estimated habitat and incidental take limits for golden-cheeked warblers and black-capped vireos during the 5-year term of this ESMP. ...................................92

3 Cave associated species known from Fort Hood...................................................93

4 Status of biological collections in surveyed (interior dimensions mapped) caves of Fort Hood.

5 Status of biological collections in unsurveyed (interior dimensions not mapped) cave and karst features of Fort Hood.

6 Parameters entered into the population viability analyses of the Goldencheeked Warbler and the Black-capped Vireo presented in Appendix B.

\section{Figures}

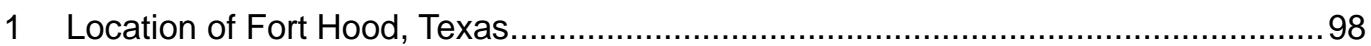

2 Training area designations on Fort Hood, Texas..................................................... 99

3 Historical breeding range of golden-cheeked warblers in Texas........................... 100

4 Current distribution of golden-cheeked warbler and black-capped vireo habitat

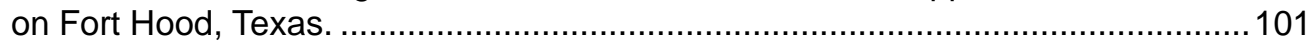

5 Current breeding range of black-capped vireos............................................... 102

6 Extinction probability of golden-cheeked warblers and black-capped vireos as a function of carrying capacity of singing males.

7 Simulation of estimated black-capped vireo and golden-cheeked warbler population size as a function of carrying capacity.

8 Endangered species overlay for Fort Hood 1:50,000 training area maps 105

9 Location of golden-cheeked warbler intensive study areas on Fort Hood, Texas. 106

10 Location of black-capped vireo intensive study areas on Fort Hood, Texas. 107

11 "Environmental Watch Areas" identified by the Fort Hood Natural Resources Branch and G3 for implementation of endangered species monitoring activities in live-fire areas on Fort Hood. 


\section{Introduction}

\section{Background}

Fort Hood Military Reservation is an 87,890-ha U.S. Army installation located in central Texas (Figure 1). (All figures and tables are placed at the end of the report.) Fort Hood provides resources and training facilities for active and reserve units in support of the Army's mission. This mission is to maintain a total force, trained and ready to fight, to serve our nation's interests both domestically and abroad, and to maintain a strategic force capable of decisive victory. Fort Hood is one of the Army's premier installations in support of this mission. The full range of mission-related training activities are conducted on Fort Hood, including maneuver exercises for units up to brigade level, firing of live weapons, and aviation training.

In addition to these activities, the Army allows a number of other nonmilitary uses of the land on Fort Hood, including fishing, hunting, grazing, and other types of recreational activities. These uses, together with military training, affect the soil, water, vegetation, and animals that occur on the installation.

The presence of federally listed endangered species on Fort Hood (Table 1) is a significant natural resource management challenge for the Army and Fort Hood. In accordance with the Endangered Species Act (ESA) of 1973, as amended, the Army must assist in recovery of all listed threatened and endangered (T\&E) species and their habitats under the Army's land management authority.

Army Regulation (AR) 200-3 requires installations to prepare an Endangered Species Management Plan (ESMP) for all listed and proposed T\&E species. The installation ESMP should be used as a tool to achieve conservation objectives for populations of listed and proposed T\&E species and to minimize impacts on the training mission. AR 200-3 further encourages, but does not require, the development of ESMPs for all candidate species and species of concern. AR 200-3 recommends that an integrated ESMP covering all T\&E species be prepared if more than one such species occurs on an installation. U.S. Fish and Wildlife Service (USFWS) Biological Opinion for Fort Hood, Texas, J uly 26, 2000 (Appendix A) provides requirements and guidance for endangered species management on Fort Hood. An Environmental Assessment was conducted for this ESMP and 
other alternatives and a subsequent Finding of No Significant I mpact was issued (October 10, 2000; Appendix E)

The greatest T\&E species challenge on Fort Hood is management of significant breeding populations of two endangered avian species: the black-capped vireo (Vireo atricapillus) and golden-cheeked warbler (Dendroica chrysoparia). Recent USFWS recovery team meetings have recognized that populations on Fort Hood are critical to range-wide recovery of these two species (USWFS, meeting minutes, 2-3 April 1998). In addition to these species, F ort Hood provides habitat for a variety of endemic caverestricted fauna, potential transient occurrences of listed and candidate species, and other species of concern (Table 1).

To ensure that the full range of military training can be effectively accomplished on Fort Hood, the Army has developed this comprehensive, integrated ESMP for management of T\&E species on Fort Hood lands. Despite military training activities on Fort Hood, the installation presents a much less hostile environment for T\&E species than most of the surrounding landscape, which is dominated by ranching, intensive agriculture, and rapid urban development. Through implementation of this ESMP, Fort Hood is in a vital and unique position to help conserve and recover listed species.

This ESMP is written specifically for use by natural resource managers and leaders of training operations on Fort Hood to accomplish military training objectives while meeting conservation objectives for T\&E species. Implementation of this ESMP will also assist USFWS in achieving recovery objectives for these species and will provide a guide for natural resource personnel at other military installations facing similar T\&E species management and land use requirements.

\section{Objectives}

The objective of this ESMP is to provide a comprehensive plan for maintaining and enhancing populations and habitats of federally listed and candidate species and species of concern on Fort Hood while maintaining mission readiness in a manner consistent with Army and Federal environmental regulations.

\section{Approach}

Development of this ESMP is based on the concept of adaptive management. Adaptive management is founded on the idea that management of renewable 
natural resources involves a continual learning process (Walters 1986). This concept is a key guiding principle in the Department of Defense's (DoD's) ecosystem management policy (S. Goodman memorandum, 8 Aug 1994) and is promoted as an effective approach to successful T\&E species recovery.

An adaptive management approach recognizes that protection and management actions are often implemented, by necessity, with imperfect knowledge. Recognition of this uncertainty allows development of monitoring and research approaches to progressively improve knowledge, and thus enhance decision-making and management capabilities.

This ESMP is based on the premise that protection, management, inventory, monitoring, and research are necessary components of an integrated, adaptive management approach for T\&E species on Fort Hood. In this ESMP, objectives, justifications, and actions are developed and implemented under a framework that is mutually supportive of these components.

Fort Hood is in the fortunate position of being able to draw on several years of natural resource and endangered species inventory, monitoring, and research data in developing this ESMP. The T\&E species research and monitoring programs implemented by Fort Hood since 1987 are regarded by the environmental and scientific community as among the most comprehensive and credible sources of information available. Information for this ESMP was gathered from installation project status reports, from related ERDC/CERL published reports, reports from cave research, and other published and unpublished documents. Personnel from the USFWS, Texas Parks and Wildlife Department, The Nature Conservancy, and the Army provided data on distribution and abundance of T\&E species on and around Fort Hood.

Even with this wealth of available knowledge, this ESMP recognizes the current state of knowledge is incomplete in many cases and further reinforces the adaptive management concept as a necessary and continual learning process for $\mathrm{T \& E}$ species management on Fort Hood. AR 200-3 provides the mechanism for incorporating new information and approaches by requiring annual reviews and major revision of this ESMP every 5 years.

\section{Mode of Technology Transfer}

This ESMP is written to meet requirements of AR 200-3, the 2000 USFWS Biological Opinion for Fort Hood, and the ESA. It will be distributed to military and natural resource managers at Fort Hood, U.S. Forces Command (FORSCOM), 
Headquarters Department of Army (HQDA), and to state and Federal resource management agencies.

This plan will be reviewed annually and updated as required to meet conservation goals and Army mission requirements. In particular, updated information about population viability analysis models, distribution of T\&E species, new research projects, habitat changes, and land use changes should be incorporated in revisions. This ESMP will be incorporated by inclusion or by reference into the installation Integrated Natural Resources Management Plan (INRMP). Once every 5 years, the INRMP, including the ESMP section, must undergo major re vision to all parts (AR 200-3, 9-4). 


\section{Site Description and Land Use Activities}

\section{Mission and History}

Fort Hood dates to 1942 when the Army established Camp Hood to prepare soldiers for tank destroyer combat during World War II. Renamed Fort Hood, it became a permanent installation in 1950. Various armored divisions have been assigned to F ort Hood since 1946.

Fort Hood is the only installation currently assigned two divisions. The installation provides the infrastructure and training lands for the 1st Cavalry Division and the 4th Infantry Division (Mech), III Corps Headquarters and its combat aviation assets, combat support, and combat service support units. With increased emphasis on force structure changes and Base Realignment and Closure (BRAC) initiatives, Fort Hood will likely remain the largest active U.S. installation in terms of assigned personnel. Total assigned personnel authorization is approximately 45,000 soldiers.

Fort Hood provides state-of-the-art facilities to support the full spectrum of training requirements of today's modern armed forces. Installation lands and ranges provide excellent training opportunities for mechanized maneuver and small unit exercises, combined arms training, and live-fire training.

\section{Terrain}

Fort Hood is located in central Texas in Bell and Coryell Counties adjacent to the city of Killeen (Figure 1). Fort Hood lies at the northern extent of the Edward's Plateau between the cities of Waco, $64 \mathrm{~km}$ to the northeast, and Austin, $97 \mathrm{~km}$ to the south.

Central Texas' climate is characterized by long, hot summers and short, mild winters. Average monthly temperatures for the Fort Hood area range from a low of about $8{ }^{\circ} \mathrm{C}$ in J anuary to a high of $29^{\circ} \mathrm{C}$ in J uly. Average annual precipitation is $81 \mathrm{~cm}$. Precipitation has two major seasonal peaks: the largest during April and May and a smaller one in September. 
Fort Hood lies entirely within the Lampasas Cutplains physiographic region and is within the Grand Prairies Land Resource Zone. The forces creating the Balcones Fault Zone, just east of the installation, have displaced underlying rock formations as much as $152 \mathrm{~m}$. Weathering and erosion over the past 70 million years has produced the present "cutplains" landscape characterized by the stairstep topography of a dissected remnant plateau. Numerous steep sloped hills and ridgelines rise above the flat to gently rolling plains. This benching is the result of erosionally resistant limestone cap rocks of the plateau and mesa-hill structures. These formations are generally composed of massive, structurally sound limestone or a mix of limestone and shale known as marl, which crumbles and weathers. Soil cover generally is shallow to moderately deep, clayey, and underlain by limestone bedrock. Major soil associations are described in Tazik et al. 1992.

Elevation ranges from $180 \mathrm{~m}$ to $375 \mathrm{~m}$ above sea level with 90 percent of the area bel ow 260 meters. Higher elevations occur on the western portions of F ort Hood, and the lowest at the Belton Lake shoreline adjoining the installation on the east. Surface water drains mostly in an easterly direction. Most slopes are in the 2 to 5 percent range. Lesser slopes occur along flood plains, while slopes in excess of 45 percent occur as bluffs along flood plains and as side slopes of mesahills.

Fort Hood lies in the Cross Timbers and Prairies vegetation area of Texas, which normally is composed of oak woodlands with a grass undergrowth. Woody vegetation on the installation is derived mostly from the Edward's Plateau vegetational area to the southwest and is dominated by Ashe juniper, live oak, and Texas oak. The grasses are derived from the Blackland Prairie area to the east. Under climax condition, these would consist of little bluestem and indiangrass.

Data obtained from the Army's Land Condition Trend Analysis (LCTA) Program at Fort Hood show that the installation is divided mainly into perennial grassland (65 percent) and woodland (31 percent) community types (Tazik et al. 1992), with relatively little shrubland. Most of the grasslands exhibit a dense or closed vegetative cover (83 percent). As a result of a long history of grazing and military activity, the installation's grasslands are dominated by Texas wintergrass (29 percent) and prairie dropseed (18 percent), with little bluestem grasslands comprising only 9 percent of the grassland area (Tazik, Grzybowski, and Cornelius 1993). Broadleaf woodlands comprise about 39 percent of LCTA woodland sites and typically are dominated by oaks. Coniferous and mixed woodlands comprise 61 percent and are dominated by Ashe juniper or a mixture of juniper and various oaks. 


\section{Current Military Activity}

\section{Maneuver Training}

Maneuver training exercises are conducted at all unit levels to ensure a combat ready fighting force. Training programs focus on units attaining and maintaining proficiency in collective tasks that support mission essential tasks. Units involved in the training process span all echelons from section to corps. III Corps' primary training focus at Fort Hood is the brigade level and below.

Units train as they will fight. Training exercises replicate combat conditions as closely as possible. Combat effects such as smoke, noise, and simulated nuclear, biological, and chemical conditions are integrated into every training event to condition units for operations in a difficult, stressful battlefield environment. Trainers are careful not to "simulate" or "assume away" any facet of a training mission. For example, units conducting defensive operations "dig-in" vehicle fighting positions and actually emplace the barrier and obstacle plan in those areas that have been previously approved for subsurface excavation by environmental and archaeological managers. This level of training realism ensures a high level of combat readiness.

Units train for combat in a task-oriented manner. Trainers integrate combat, combat support, and combat service support elements to conduct multiechelon, combined arms training. Combined arms training involves formations that include members of the entire fighting force. Commanders synchronize the activities of these forces within a battlefield framework that includes maneuver and operations within the deep, the close-in, and rear battle areas. Such exercises involve greater depth and rapidity of movement dimensions and, therefore, also incur greater demands for concurrent land use.

Such training can damage soil and vegetation. The extent of this damage depends largely on weather conditions, visibility, and the inherent land capability. Ground and woody vegetation may be damaged or displaced by these operations. This damage is not indiscriminate; environmentally protected areas (archaeological, T\&E species habitat, and conservation and recreation areas) are identified to protect them from training damage.

\section{Live-fire Training}

Weapons proficiency is a critical component of combat power. Fort Hood units train with the most modern and sophisticated weapon systems available. These weapons are constantly evolving to stay ahead of advancements in armament 
technology by threat forces. Fort Hood has some of the most modern live-fire training ranges in the world. These ranges provide realistic combat conditions and scenarios to train crews to exacting standards of gunnery proficiency as well as test the capabilities of new weapons system. Live-fire training facilities must be continuously upgraded to keep pace with evolving technology and changes in war fighting doctrine. Fort Hood uses a 5-Year Range Modernization Program to manage upgrades and expansion of existing facilities and new construction projects to meet future training and evaluation requirements. Live-fire training facilities are located primarily in Training Ranges or Training Areas (TA) 61 through 93 and the Artillery Impact Area (TA 94; Figure 2).

Modernized live-fire training facilities require continuous maintenance to maximize range design capability. Sensor devices must be serviced and cleared of concealing vegetation to ensure unimpaired operation. Target arrays must be visible at maximum engagement ranges. A program of range maintenance to routinely clear vegetation from target arrays and sensor devices is a critical component of range operation.

\section{Aviation Training}

Fort Hood has one of the largest military aviation commands in the United States. The aircraft, primarily rotary-wing, are some of the most modern and sophisticated in the world. Aviation units on Fort Hood train at all echelons from individual through battalion/squadron.

The training tasks accomplished in the training areas (Figure 2 ) include all tactical maneuvers in accordance with each aircraft's aircrew training manual and the unit's standard operating procedures. This includes nap-of-earth, contour, and low level flight. Fixed-wing aircraft of the Air Force and Air National Guard also conduct training missions in Fort Hood air space and use impact areas on the installation for weapons delivery practice.

Aircraft gunnery for AH-64 units is conducted on multipurpose training ranges and the Artillery Impact Area (TA 94). However, the Dalton-Henson Range Complex (TAs 61 and 62) is used most often for this training. Hellfire Missile Shots are conducted at Blackwell Multi-Use Range's I mpact Area (TA 91). Helicopter Door Gunnery is primarily conducted at Dalton Mountain Range or Crittenburger Range (TAs 74 and 75). National Guard and Army Reserve units use the Dalton-Henson Range Complex for aviation training. 


\section{Operational Testing}

Fort Hood's large maneuver and Live-fire Training Areas, coupled with III Corps modernized force, provide excellent conditions for operational testing of various weapons, equipment, and doctrine. The U.S. Army Test and Experimentation Command (TEXCOM) is a tenant activity located at West Fort Hood. TEXCOM is directly involved in training, doctrine, and combat development of the products that soldiers use on a daily basis and will use on the future battlefield.

Most TEXCOM tests employ "user testing," allowing front-line soldiers to try out new equipment or concepts. The tests generally encompass activities similar to those described in this report's sections on maneuver, live-fire, and aviation training.

\section{Training Grounds}

\section{Maneuver Training Areas}

Maneuver training areas are located west, east, and southwest of the Live-fire Training Areas (Figure 2). Maneuver training areas constitute 53,300 ha or 61 percent of the entire installation. The West Range Maneuver Training Areas (TAs 30 through 53) provide excellent training opportunities for large armored and mechanized infantry forces. The training area averages 7 to $10 \mathrm{~km}$ east to west and $30 \mathrm{~km}$ north to south. The area features a wide variety of terrain and vegetation characteristics that greatly enhance cross country, combined arms maneuver. Because of its large, contiguous size, this is the only maneuver area on F ort Hood capable of supporting brigade-level operations.

The Northeast (TAs 1 through 7) and Southeast Range Maneuver Training Areas (TAs 11 through 19) are divided by Belton Lake Reservoir. The northeast sector is heavily vegetated and cross-compartmentalized, providing limited value as a mechanized maneuver area. The southeast sector provides more favorable terrain for mechanized units, but is only 4 to $7 \mathrm{~km}$ north to south and $15 \mathrm{~km}$ from east to west. Because of limited area, the Northeast and Southeast Range Maneuver Training Areas are best suited for unit assembly and logistical areas, artillery firing points, and company- and platoon-level mounted and dismounted training. Additionally, these eastern training areas support engineer, combat support, and combat service support training, and provide locations for amphibious and river crossing operations. 
The Southwest Maneuver Training Area does not support intensive mechanized training due to its small size and isolated location, but can support up to company level training. The Southwest Maneuver Training Area (TAs 21 through 27; "Southwest Fort Hood") is separated from the main cantonment area by U.S. Highway 190. This training area includes many restricted areas, including Robert Gray Army Airfield and the Ammunition Supply Point (ASP). The Southwest Maneuver Training Area is used primarily for small mechanized unit and dismounted infantry training and for logistical sites.

\section{Live-fire Training Areas}

The Live-fire Training Areas and Artillery Impact Area (Figure 2) cover about 24,000 ha in the central portion of the installation, bounded on the east, west, and south by the East Range, West Range, and South Range roads, respectively. Direct fire occurs inside these roads, and is directed toward the Artillery I mpact Area and other target arrays. Indirect fire from artillery and Multiple Launch Rocket Systems (MLRS) is directed from numerous locations in surrounding maneuver areas. Much of the live-fire area provides a buffer zone for the Artillery Impact Area and has limited impacts from exploding ordnance. The Live-fire Training Areas provide training and evaluation facilities for all individual, crewserved, and major weapons systems, up to and including brigade live-fire. These live-fire ranges are used by all active units assigned to III Corps and Fort Hood, as well as by attached units from the Army National Guard and the Army Reserve.

\section{Air Operations}

Two major airfields are located on Fort Hood. The Hood Army Airfield is a 293ha area located at the eastern end of the cantonment area. Hood Army Airfield is the primary airfield for rotary-wing air operations and has a $1436 \mathrm{~m}(4712 \mathrm{ft})$ runway. Robert Gray Army Airfield is an 867-ha area located at West F ort Hood with a $3050 \mathrm{~m}(10,000 \mathrm{ft})$ runway. Several dirt landing strips are located on the installation for tactical air supply and support training.

\section{Explosives Storage and Handling}

The installation's main supply and storage area for ammunition and ordnance needed for training activities and for initial operational requirements is located in the Ammunition Supply Point at West Fort Hood. Ordnance demolition by the 47th Explosive Ordnance Disposal Detachment takes place at Range 57 in Training Area 75. 


\section{Other Current Activities}

\section{Controlled/Prescribed Burning}

Prescribed fire is a natural, economical, and effective management practice in some ecosystems. During the past 150 years in Texas, fire suppression practices have contributed substantially to the ecological imbalance of endangered species habitats. In many instances, properly applied fire can be one of the better tools to correct this problem. Fire presents a particular dilemma for the management of endangered species on Fort Hood. Fire can destroy the habitat of the goldencheeked warbler while creating habitat for the black-capped vireo (see "Species Accounts," Chapter 3). Because of fire's potential effects, both positive and negative, on endangered species habitats, it plays an important role in management of these habitats on Fort Hood.

According to the 1985 Fort Hood Natural Resource Management Plan, a total of 4050 ha were targeted for controlled burning during 1986 through 1990 to eliminate Ashe juniper and improve wildlife habitat. In reality, 13,760 ha of grassland were actually treated by controlled burning between 1986-1989. No burning was performed in 1990 in reaction to a fire at Lone Mountain that temporarily destroyed black-capped vireo habitat.

During extremely hot and dry conditions in late February 1996, approximately 2728 ha of endangered species habitat were burned by wild fires on Fort Hood. This included about 2313 ha of warbler habitat and 415 ha of vireo habitat. Although this is a setback for warbler management, it provides an excellent opportunity for a substantial increase in total available vireo habitat. New fire protection policies have been implemented on Fort Hood as a result of the 1996 fires and consultation with the USFWS (see Appendix B).

Current prescribed burn fire policy emphasizes reduction of fuel loads in grasslands surrounding T\&E habitats on Fort Hood. Reduction of fuel loads mitigates the threat of wild fire damage in these habitats. Prescribed burns are managed through the Fort Hood Natural Resources Branch. Other objectives of the installation prescribed burn program are to reduce encroachment of Ashe juniper in all range sites, improve vegetation composition, and improve wild ife habitats.

\section{Juniper Cutting}

An extensive program for the removal of Ashe juniper from maneuver training areas was conducted prior to 1990 to allow for more effective training using laser simulators. This involved juniper removal primarily from the tops of the mesa- 
hills in several West Maneuver Training Areas (TAs 34, 35, 36, 41, 42, 43, 44, 45, 48, 51, and 53). However, in many cases, contractors also removed juniper and other brush from side slopes. There has been limited cutting on Southeast Maneuver Training Areas (TAs 12, 13, 15, and 16).

The 1985 Natural Resource Management Plan called for brush cutting for habitat improvement on approximately 3840 ha for the period 1986 to 1990. Of this, 2225 ha were to be clearcut and 1615 ha were to be hand cleared. Additionally, during 1986 to 1989, a contract for juniper clearing on the west side of the reservation involved $8700 \mathrm{ha}$. Areas selected were chosen primarily to increase available training space for the military. Areas where pure stands of juniper were present received top priority for cutting. Other areas cut were preferred training sites that had become too thick for training due to juniper encroachment.

After the listing of the golden-cheeked warbler in May 1990, juniper cutting on Fort Hood was suspended temporarily following informal consultation with the USFWS. Since Ashe juniper is an essential component of the habitat for this endangered bird species, it was determined that juniper cutting could have a negative impact.

During the period 1997 to 2000, under an agreement with the Natural Resources Conservation Service (NRCS), Fort Hood resumed mechanical clearing of juniper in old-field and other areas unlikely to be occupied by golden-cheeked warblers. These control efforts were focused on juniper removal on West Maneuver Training Areas and resulted in clearing juniper from approximately 14,500 ha of old fields and other non-endangered species habitat areas. All control efforts and contracts were coordinated through the Fort Hood Natural Resources Branch to avoid impact on endangered species habitats. Control efforts were not allowed within a 100-m buffer around endangered species habitats.

\section{Grazing}

Cattle grazing is permitted on Fort Hood under a lease agreement with the Central Texas Cattlemen Association. The period of this lease is 5 years ending March 2001. This lease provides grazing opportunities on 200,000 acres of Fort Hood land supporting a maximum of 3500 animal units. The lease agreement requires the lessee not to impact endangered species, historical, archaeological, architectural, or other cultural features on the installation, and requires compliance with local, state, and Federal water pollution regulations. This lease agree ment is currently under review by theArmy. 
The NRCS, under contract with Fort Hood, completed range studies in 1998 to establish recommended stocking rates by installation training area. Results of this evaluation were provided to the USFWS.

\section{Recreation}

The post is open to public hunting and fishing. Access is regulated by the Range Control Division, Area Access office with the cooperation of Morale Support Activities and the Natural Resources Branch. Over 80,500 ha are managed for fish and wildlife, including 100 surface ha of lakes and ponds, $88 \mathrm{~km}$ of rivers and permanent streams, and $85 \mathrm{~km}$ of shoreline access to Belton Lake. In recent years, the installation has provided 90,000 fisherman-days and 45,000 hunterdays annually. Whitetailed deer, wild turkey, migratory waterfowl, northern bobwhite, and mourning dove are hunted during restricted seasons. Deer and turkey hunts are carefully controlled. Small game hunting with shotgun is available in accordance with State of Texas seasons and bag limits.

Off-road vehicle (mechanized and nonmechanized) use is restricted to TA 34D and the Belton Lake Outdoor Recreation Area.

Various low-impact outdoor recreation activities take place at the Belton Lake Outdoor Recreation Area located adjacent to TA 17. These include a swimming beach, camping, boating, and cottage use. Boy Scout Camps are located in TAs 17 and 23. Hiking and nature observation activities are also allowed on many parts of the installation and are coordinated through Range Control Division. 


\section{Species Accounts and Current Status on Fort Hood}

\section{Golden-cheeked Warbler}

\section{Nomenclature and Classification}

Scientific Name: Dendroica chrysoparia

Family: Emberizidae

Original Description: Sclater and Salvin 1860

Type Specimen: Adult female collected by Osbert Salvin near Tactic, Vera Paz, Guatemala on 4 November 1859. Specimen in the British Museum 1885-3-8-262. Current Federal Status: Endangered (55 FR 53153-53160 [27 December 1990]).

Past F ederal Status: Emergency listing as Endangered (55 FR 18844-18845 [4 May 1990]); Category 2 (47 FR 58454 [30 December 1982], 50 FR 37958 [18 September 1985], 54 FR 554 [6 J anuary 1989]).

\section{History of the Taxon}

The name of this species has not changed since the original description of a specimen collected in Guatemala (Sclater and Salvin 1860). The first U.S. specimen was collected by D.C. Ogden in Bexar County, Texas (Dresser 1865). The species may have originated as part of a superspecies complex including the black-throated green warbler, the Townsend's warbler, and the hermit warbler (Mengal 1964; Lytle 1994). The definitive and only major bioecological study of the golden-cheeked warbler was completed by Pulich (1976). Sections of this study have been updated in Ladd and Gass (1999).

Because of rapid urban development, there is considerable interest in the status of the species in the Austin-San Antonio corridor. The Army is conducting studies of the species on Fort Hood, Texas and the Camp Bullis Training Site of Fort Sam Houston, Texas.

FORT HOOD: Monitoring and research activities for the golden-cheeked warbler on Fort Hood were initiated in 1991 and continue through the present. Cur- 
rent and past research and conservation efforts include point count surveys to determine population trends, demographic and reproductive monitoring in selected study sites, research in habitat selection, studies to determine the effects of habitat fragmentation and wildfire on golden-cheeked warbler demographics, and population viability analyses.

\section{Description}

The golden-cheeked warbler is a small, strikingly colored songbird approximately $13 \mathrm{~cm}$ in length, and 9 to 10 grams in weight. Detailed descriptions can be found in Pulich (1976), Oberholser (1974), and Ladd and Gass (1999). Adult males exhibit bright yellow cheeks outlined in black, with a black line through the eye. The upper parts, throat, neck, and upper breast are black with additional black streaking along the flanks. The wings are black except for two distinct white bars. The black tail is interrupted with white on the three outermost feathers. Adult female plumage is duller than that of the male, with a blackstreaked olive back, a yellowish throat, and a blackish upper breast. The cheeks of female and immature birds are not as bright as that of the male. The back of immature birds also is streaked with green. Immatures often cannot be sexed based on plumage characteristics.

FORT HOOD: Plumage characteristics are consistent with those within the range.

\section{Geographic Distribution}

The golden-cheeked warbler is the only North American bird species whose breeding range is restricted to a single state (Texas). Historically, it has been recorded in 41 of the 254 counties in Texas (Figure 3). It is a species characteristic of the Hill Country of central Texas, inhabiting mature juniper-oak woodlands of the Edward's Plateau. The range of the golden-cheek corresponds closely with that of Ashe juniper (Pulich 1976).

At the time of Pulich's publication, only 31 counties were thought to be occupied. A recent status survey did not examine the extremes of the range (Wahl et al. 1990). Participants in the 1995 warbler population viability workshop noted that warblers are presently found in 24 counties (Beardmore 1994). Another 12 counties need further study to determine occupation by warblers.

Based on an extensive review of existing records, Pulich (1976) concluded that the species winters in mountainous areas (between 1400 and 2000 m; Thompson 1995) of east-central Guatemala through Honduras to Nicaragua, but that the 
exact winter range was not yet well defined. The presence of wintering birds in Mexico was considered questionable. However, more recent evidence suggests that the species may overwinter in the state of Chiapas in extreme southern Mexico (Braun et al. 1986; J ohnson et al. 1988; Perrigo et al. 1990; Vidal et al. 1994).

FORT HOOD: Figure 4 shows the distribution of potential warbler habitat based on visual interpretation of aerial photography and ground surveys. Table 2 shows the total estimated area of warbler habitat. Warbler occurrence is widespread and has been documented in all training areas with suitable habitat on the installation.

\section{Migration}

The golden-cheeked warbler is a migratory species, arriving early on its breeding grounds in Texas. The earliest spring arrival known to Pulich (1976) was a 2 March arrival in Austin during 1956. It is not certain whether male warblers arrive earlier than females. The mean spring arrival date for Bexar, Dallas, Kerr, and Travis Counties was between 12 and 16 March.

The species begins post-breeding migration rather early, with some birds headed toward their wintering grounds as early as mid J une (Pulich 1976). The main portion of the population leaves the breeding grounds by the end of J uly (Ladd and Gass 1999). The earliest fall record in southern Mexico was 5 Aug (Ladd and Gass 1999).

FORT HOOD: The earliest documented spring arrival on Fort Hood is $2 \mathrm{March}$. Peak arrival period is between 15 and 25 March. Similar to other populations throughout the range, most warblers on Fort Hood begin migration by the end of July.

\section{Habitat}

General: The USFWS recovery plan provides a general overview of warbler habitat requirements (USFWS 1992). Golden-cheeked warbler habitat includes Ashe juniper and a variety of oak species. Several other hardwood species also occur (Pulich 1976). Fifteen stands sampled by Wahl et al. (1990) were dominated by Ashe juniper and Texas oak. Other important tree species included live oak, cedar elm, Lacey oak, Arizona walnut, post oak, and bigtooth maple. Studies by J ohnston et al. (1952) and Huss (1954) reported juniper-oak stands occupied by the golden-cheeks with juniper composition of 14 to 50 percent and hardwood composition of 20 to 70 percent. For good warbler habitat at Meridian 
State Recreation Area, Kroll (1980) reported 52 percent Ashe juniper, 33 percent shin oak, and 5 percent Texas oak. Similarly, the most important species in warbler habitat at Kerr Wildlife Management Area were Ashe juniper, Texas oak, and shin oak (Ladd 1985). While Ashe juniper is the dominant woody species throughout the warbler range, the composition of oak species varies geographically (Ladd 1985; Ladd and Gass 1999).

Pulich (1976) suggested that the golden-cheeked warbler requires woodland habitat with junipers averaging 50 years of age and 20 feet $(6.1 \mathrm{~m})$ in height with some deciduous cover. Kroll (1980) quantified habitat of the species at Meridian State Recreation Area and found that 86 percent of the junipers within the study area were less than 50 years old (average $40.8 \pm 29.4$ years). Good habitat that was consistently occupied from year to year differed significantly from unoccupied areas. Good habitat was characterized by older Ashe juniper (mean of 47.4 vs. 25.6 years of age in good vs. poor habitat) but a greater variability in age, greater distance between trees, and a smaller juniper:oak density ratio (1.35 vs. 2.77). The warbler appears to be attracted to more mesic areas within the juniper-oak complex, such as canyons and seepy hill sides where deciduous hardwood vegetation is more abundant (D. Diamond, Biologist, Texas Nature Conservancy, professional communication). Recent observations indicate warblers will reoccupy second growth areas (Ladd, Consulting Biologist, professional communication; Diamond, professional communication) presumably in areas that have the appropriate mixture of juniper and deciduous oaks. Arnold, Coldren, and Fink (1996) reported that 23 ha may be the minimum threshold size of habitat in which golden-cheeks can produce young. Coldren (1998) found that golden-cheeked warblers select for habitat patches $>100$ ha.

FORT HOOD: Warblers on Fort Hood occupy similar habitat to that described above.

Nest Sites: Chapman (1968) reported that the favorite nesting areas of the gol den-cheeks were "isol ated patches or clumps of scrubby cedar, with scant foliage on the summits of the scarped canyon slopes and in the thick cedar 'brakes"' (p 166). Nests are placed in juniper trees and a variety of hardwood tree species (Chapman 1968; Pulich 1976; Timothy J. Hayden, Ecologist, ERDC/CERL, unpublished data). Nest height varies from 1.8 to $6.5 \mathrm{~m}$, averaging $4.6 \mathrm{~m}$ (Brewster 1879; Chapman 1968; Pulich 1976). Nests average $8 \mathrm{~cm}$ in external width and 5 $\mathrm{cm}$ in external depth. They are composed mostly of bark collected in strips from juniper trees. Kroll (1980) estimated that juniper bark does not start to peel sufficiently for warblers to collect until juniper trees are about 20 years old. 
FORT HOOD: Nests have been found in Ashe juniper, Texas oak, post oak, Texas ash, and live oak trees. Nests found in 1996 were between $3.25 \mathrm{~m}$ and 7.6 $\mathrm{m}$, with an average height of $5.25 \mathrm{~m}$. Nests were found in the top one-quarter of the tree (mean tree height $6.95 \mathrm{~m}$ ), and generally found in the outer portions of the branches.

Foraging Site: The golden-cheeked warbler forages for insects in tree canopies (Smith 1916; Simmons 1924; Pulich 1976). Essential foraging habitat is provided by oak species within the habitats occupied (Kroll 1980; Ladd 1985; Wahl et al. 1990). Beardmore (1994) reported that oaks were used out of proportion to availability during April, but in proportion to availability during May and $\mathrm{J}$ une. Fifty-seven percent of the foraging observations made by Kroll (1980) found warblers in oaks. Beardmore (1994) also reported foraging differences between male and female golden-cheeked warblers.

FORT HOOD: No data are available on foraging preferences on Fort Hood although foraging behavior is likely similar to that observed in other parts of the warbler's range.

\section{Food Resources}

The golden-cheek is considered a generalist, consuming a wide variety of arthropods including Lepidopterans, Coleopterans, Hemipterans, Homopterans, Hymenopterans, Dipterans, Psocopterans, and Arachnids (Pulich 1976; Wharton et al. 1996). Kroll (1980) observed that most prey items used by the warbler were of Lepidopteran larvae (54 percent) and Orthopterans ( 13 percent).

FORT HOOD: No data are available on food resources on Fort Hood although food resources are likely similar to that observed in other parts of the warbler's range.

\section{Population Estimates}

Pulich (1976) estimated that the breeding population of the warbler in 1962 and 1974 was between 15,000 and 17,000 birds. Wahl et al. (1990) estimated a range of 4822 to 16,016 individuals in 1989 . The two estimates are not directly comparable, because they were derived in different ways (Wahl et al. 1990). Also, Wahl et al.'s estimate may be inflated since not all males are mated and all available habitat may not be fully occupied at the assumed average density of 15 pair per 100 ha. 
Population estimates were derived from estimates of habitat availability and population density. Most studies report golden-cheek territory sizes ranging from 1.9 to 4.3 ha per pair (Ladd 1985). Wahl et al. (1990) reported density estimates of 0 to 62.5 males per 100 ha with a median of 15 per 100 ha for several sites throughout the golden-cheeked warbler's range. Pulich (1976) classified warbler habitat into excellent, average, and marginal corresponding to 12.3, 5.0, and 2.9 pair per 100 ha.

FORT HOOD: In 1996 on Fort Hood, 915 singing males were documented. The number of males documented on point count transects has increased from 0.87 per point in 1992 to 1.09 in 1996. In one, intensively studied 178 ha area in TA $13 \mathrm{~B}$ on Fort Hood, warbler densities have ranged from 13.5 singing males per 100 ha in 1992 to 28.1 per 100 ha in 1995 (J ette, Hayden, and Cornelius 1998). The current estimate of available warbler habitat on Fort Hood is 21,496 ha. Assuming densities in all potential habitat on Fort Hood are equivalent to densities in the one intensively surveyed area, the total estimated population of goldencheeked warbler males on Fort Hood is 2901 to 6040 singing males.

\section{Survival and Dispersal}

One-year banding returns reported by Pulich (1976) were 44.8 percent for males and 22.2 percent for females. USFWS (1996) estimated 30 percent juvenile and 57 percent adult annual survival.

FORT HOOD: USFWS estimates of juvenile and adult survival were based on mark-recapture analysis of Fort Hood banding return data (USFWS 1996). In the intensive study area in TA 13B, one-year banding returns of adult males ranged from 30 percent (15 of 50 males) in 1996 to 65.6 percent (21 of 32 males) in 1995, averaging 48 percent (61 of 127) for the period 1992-96 (J ette, Hayden, and Cornelius 1998). Although the overall adult female return rate was 14.5 percent, this number likely is an underestimate due to the secretive behavior of female golden-cheeked warblers. Return rates of juveniles were 16.9 percent (males) and 9 percent (females). These observed return rates probably underestimate juvenile survival since juveniles frequently disperse relatively long distances from their natal areas.

The mean resighting distance (one-year post banding) for males banded as $\mathrm{HY}$ juveniles was 4,040 $\mathrm{m}(\mathrm{N}=24, \mathrm{SD}=4,777)$. The mean resighting distance for female HYs was $1,525 \mathrm{~m}(\mathrm{~N}=7, \mathrm{SD}=1,388)$. This compares with a mean resighting distance for AHY males of $223 \mathrm{~m}(\mathrm{~N}=268, \mathrm{SD}=307)$ and for AHY females of $322 \mathrm{~m}$ $(\mathrm{N}=11, \mathrm{SD}=294)$. 


\section{Reproductive Biology}

The golden-cheeked warbler is sexually monogamous. Individual pairs establish exclusive breeding territories within which they nest and forage. The nesting cycle is as follows: construction (4-5 days), inactive construction (3-4 days), laying (4 days), incubation (11-12 days), nestling (9 days), fledgling feeding (28-45 days). Some nest construction may be initiated during late March, but most occurs during early April (Pulich 1976). Clutches typically consist of four eggs, sometimes three, and rarely five. The species is not commonly double-brooded, although pairs will renest after a failed nesting attempt.

The female performs most of the nesting duties (Pulich 1976). While males assist in feeding young during the nestling stage, they do not brood the young.

Of the 33 nests observed by Pulich (1976), 58 percent were parasitized by brownheaded cowbirds (cowbirds hereafter). Of the 55 eggs laid, 55 percent were lost or deserted due to cowbirds. Twenty-seven percent of the eggs laid fledged young.

FORT HOOD: Productivity has been relatively stable, ranging from 1.63 young per territory in 1996 to 2.06 in 1995 . Percentage of successful males has also remained stable, ranging from 86 percent in 1996 to 96 percent in 1995. In the Fort Hood Intensive Study Area observed mating success has ranged from 79 to 94 percent during 1992-96, with overall average mating success of 89 percent for adult males (J ette, Hayden, and Cornelius 1998).

A total of 35 warbler nests have been found on Fort Hood between 1991 and 1996. Golden-cheeked young fledged from 27 nests. Two nests fledged only cowbird young, one fledged young of both species. Six nests were either depredated or abandoned, and the fate of eight nests was unknown. Thus, the minimum estimate of parasitism for nests of known fate on Fort Hood is 11 percent (three of 27 nests).

On three occasions, observers have seen cowbird young in association with warbler adults. In two of these observations, an adult was caring for young of both species. In the third case, an adult warbler was seen feeding a cowbird young in a cowbird trap.

Six instances of double-brooding have been observed on Fort Hood. 


\section{Interactions with other Species}

Habitat Associates: Other breeding birds found in association with the goldencheek throughout most of its range include the black-and-white warbler, mourning dove, yellow-billed cuckoo, greater roadrunner, eastern screech owl, greathorned owl, barred owl, American crow, red-tailed hawk, red-shouldered hawk, common grackle, blue jay, western scrub jay, cliff swallow, chuckwill's widow, Carolina chickadee, Bewick's wren, Carolina wren, canyon wren, northern flicker, downy woodpecker, eastern tufted titmouse, bluegray gnatcatcher, white-eyed vireo, brown-headed cowbird, summer tanager, northern cardinal, painted bunting, and lark sparrow (Pulich 1976; Arnold, Coldren, and Fink 1996; J ette, Biologist, ERDC/CERL, professional communication).

Arnold, Coldren, and Fink (1996) reported that, of the 23 predators and parasites found in association with the golden-cheek, only the brown-headed cowbird, greater roadrunner, and red-tailed hawk were found more frequently with warblers than without.

FORT HOOD: Similar habitat associates are observed on F ort Hood.

Competition: There probably is little competition from other birds of the same family as the golden-cheek occupies such a narrow ecological range (Pulich 1976).

FORT HOOD: Aggressive interactions are observed between the closely related black-throated green warblers and golden-cheeked warblers on F ort Hood during migration. Black-throated green warblers are not resident breeders in Texas. No aggressive interactions have been observed with other species. No intraspecific competition has been observed to date as a result of territory shifts due to the 1996 habitat loss (J . Cornelius, Biologist, Fort Hood, TX, professional communication).

Depredation: Direct depredation on adults has not been observed frequently. However, nests are depredated by snakes, grackles, jays, and possibly squirrels (Pulich 1976; Pease and Gingerich 1989). Red fire ants are a potential problem (Pulich 1976).

FORT HOOD: One nest on F ort Hood (and possibly a second) was depredated by red fire ants. Currently, Fort Hood is monitoring nests with video cameras and snake predation of adults and nest contents have been recorded. 
Parasites: Pulich (1976) observed no mites or ectoparasites in golden-cheeked warbler nests.

FORT HOOD: Small white mites have been observed on the rectrices of adult warblers during banding. No other data are available on parasites of warblers on Fort Hood.

\section{Threats to Survival}

Threats to gol den-cheeked warbler identified in the 1994 Recovery Plan (USFWS 1992) included breeding habitat loss, loss of winter and migration habitat, habitat fragmentation, nest parasitism by cowbirds, and destruction of oaks. A more recent Population Viability and Habitat Analysis (PVHA) document (USFWS 1996) also identifies concerns related to reservoir development, oak wilt, predation, and secondary effects of urbanization in proximity to warbler habitats.

Habitat loss is attributed to urban development and clearing associated with agricultural practices. Pulich (1976) estimated a juniper eradication program for range improvement reduced juniper acreage in Texas by 50 percent between 1950 and 1970. Wahl et al. (1990) reported warbler breeding habitat loss of approximately 4 percent per year over a 10-year period in urbanizing areas and about 2 to 3 percent per year in rural areas during the past 20 years. This work was based on satellite imagery from 1974 through 1981. More recent satellite imagery may show that the rate of habitat loss has increased in recent years (Grzybowski et al. 1990). Estimates of loss of wintering habitat in Central America (2 to 4 percent per year) are similar to estimated losses of breeding habitat (J ahrsdoerfer 1990; Lyons 1990).

Loss of habitat has resulted in increased fragmentation of warbler habitat. Wahl et al. (1990) estimated a 53 to 84 percent reduction in suitable habitat ( $>50$ ha in size) due to habitat fragmentation around urban areas and a 56 to 89 percent reduction in rural areas. Habitat fragmentation has been suggested as a cause of population declines in other songbird species (Gates and Gysel 1978; Brittingham and Temple 1983; Wilcove 1985; Andren and Angelstrom 1988; Pease and Gingerich 1989). However, habitat fragmentation may make warblers more susceptible to depredation by blue jays in urban areas (Engels and Sexton 1994) and more susceptible to nest parasitism by cowbirds (Brittingham and Temple 1983; Robbins et al. 1989; Thompson 1994). Coldren (1998) found that golden-cheeked warblers selected for habitat patches $>100$ ha and that territory placement selected against urban landuses including commercial development, entertainment, forested non-warbler habitat, high-density transportation, and utilities. 
Cowbird parasitism reduces productivity in host species (Brittingham and Temple 1983). Golden-cheeked warblers are susceptible to cowbird parasitism (Pulich 1976). Land use practices that increase the incidence of cowbird parasitism such as habitat fragmentation, cattle grazing, and increased urbanization may limit productivity in golden-cheeked warblers.

Oaks are a necessary component of warbler habitat. Loss of oaks in warbler habitat is attributed to disease (oak wilt fungus, Ceratocystis spp.) and overbrowsing by white-tailed deer, goats, and various exotic ungulates.

FORT HOOD: There has been no evidence to date of overbrowsing of oaks on Fort Hood (J . Cornelius, pers. comm.). Incidence of oak wilt fungus has been observed on Fort Hood. Although oak wilt currently is not thought to be a significant problem, its potential spread warrants further monitoring. While there have been no juniper eradication contracts in warbler habitats on Fort Hood since 1990, junipers are cleared from old fields that are not suitable as warbler habitat. The only significant loss of warbler habitat comes from fires. Under current training restrictions in endangered species habitats, warbler habitat is not altered significantly by military training. Maas-Burleigh (1997) reported that golden-cheek males in more fragmented landscapes reproduced less often than males in contiguous forest. 


\section{Black-capped Vireo}

\section{Nomenclature and Classification}

Scientific Name: Vireo Atricapillus Woodhouse

Family: Vireonidae

Original Description: Woodhouse 1852

Type Specimen: Adult male collected by S. W. Woodhouse on 26 May 1851 at the San Pedro River 10 mi from its source: Devil's River, near Sonora, Sutton County, Texas (Deignan 1961). Deposited in the National Museum of Natural History, number 15040.

Current Federal Status: Endangered (52 FR 37420-37423 [6 October 1987]). Past Federal Status: Category 2 (47 FR 58454 [30 December 1982]); Category 1 (50 FR 37958 [18 September 1985]).

\section{History of the Taxon}

Grzybowski (1995) provides a recent account of this species. The species was first described by Woodhouse (1852). The name has remained unchanged since his original description. Until recently, there were few major studies of the black-capped vireo. Bunker (1910) first studied nesting, stomach contents, and plumage of the vireo in Blaine County, Oklahoma. In other studies, Graber (1957, 1961) examined distribution, ecology, and population biology of the species. Marshall et al. (1985) wrote a profile of the species, focusing on the distribution and abundance in the United States and Mexico. Grzybowski has continued studies on the species in parts of Texas and Oklahoma, and authored the species Recovery Plan (USFWS 1991) and the species account for the Birds of North America publication (Grzybowski 1995). Tazik initiated research on one of the largest concentrations of nesting black-capped vireos north of Mexico, on Fort Hood, Texas (Tazik 1991). Recent research efforts include a study of alternative host densities and the incidence of cowbird parasitism in black-capped vireos by Barber and Martin (1997), the effects of prescribed burning on blackcapped vireo habitat and vireo nesting dynamics by O'Neal et al. (1996), and a population estimate for the breeding population in Mexico by Benson and Benson (1990). Army-sponsored studies are on-going at Fort Hood, Texas; the Camp Bullis Training Site, Fort Sam Houston, Texas; and Fort Sill, Oklahoma. Other monitoring and research activities are ongoing on other local, state, and Federal properties in Texas.

FORT HOOD: Research and conservation efforts on Fort Hood have included an inventory and monitoring program, remote camera studies of nest depredation and assessment of training activities in endangered species habitats, a habi- 
tat restoration program, a study of researcher activities on nesting vireos, a nest site/habitat analysis, assessment of cowbird movements and activity, and a cowbird parasitism control program.

\section{Description}

The black-capped vireo is a small songbird approximately $11 \mathrm{~cm}$ in length and 10 grams in weight. The sexes are dimorphic. On the adult male, the crown and upper half of the head is black and sharply demarcated. Black extends farther posterior on older males. The back is olive-green and undersides are white with olive-yellow flanks. Wings have olive-yellow-black plumage colors with two light yel lowish wingbars. The adult female is similar in color except for a gray crown, often with some black around the white eye mask, and under parts washed with greenish yellow. Adults have a red to reddish-brown iris. Immature birds are browner above, and buffy below (Grzybowski 1995).

\section{Geographic Distribution}

The breeding range of the black-capped vireo formerly stretched from southcentral Kansas through central Oklahoma and central Texas into central Coahuila, Mexico, and possibly Nuevo Leon and Tamaulipas (Figure 5; Graber 1961, American Ornithologists Union 1983). The northern extent of the range has contracted significantly over the past half-century (Grzybowski 1995; Grzybowski et al. 1986). The species has not been observed in Kansas since the late 1950s (Tordoff 1956; Graber 1961) and reaches its northern limit in Blaine County, Oklahoma (Grzybowski et al. 1986). The vireo appears to be gravely endangered in Oklahoma (Grzybowski et al. 1986; Grzybowski 1987; Ratzlaff 1987) and is declining in many areas of Texas (Grzybowski 1995; USFWS 1991). Blackcapped vireos have been reported in at least 40 counties in Texas (Beardmore and Hatfield 1995).

FORT HOOD: A single black-capped vireo vocalization was reported in a 1979 baseline ecological report for Fort Hood. Vireos were subsequently observed in 1985 by J ohn Cornelius, a biologist with the Natural Resources Branch at Fort Hood. These initial findings comprised a small number of birds (Tazik et al. 1993a). Inventory, monitoring, research efforts were initiated in 1987 and continue through the present. Current known vireo habitat on Fort Hood is shown in Figure 4. Vireos are known to exist elsewhere on the installation, but are typically in isolated territories within habitat shown in Figure 4 as goldencheeked warbler habitat. 


\section{Migration}

The black-capped vireo is migratory and is known to winter along the western coast of Mexico from Sonora to Oxaca (Graber 1961). Although extensive winter surveys have not been done, most observations have been recorded in Sinaloa and Nayarit (Grzybowski 1995). Vireos first arrive on Texas breeding areas during late March to mid-April, and in Oklahoma during mid-April to early May (USFWS 1991). Fall migration takes place during August and September. Graber (1961) reports that young birds leave first, followed by adult females, and then adult males.

FORT HOOD: On Fort Hood, males typically are first observed in late March or early A pril. It is suspected that females arrive shortly thereafter. Many males are no longer strongly territorial by the end of J uly, although some have nested into August. Most black-capped vireos appear to have departed by midSeptember.

\section{Habitat}

General: The black-capped vireo is found in hardwood scrub habitat that typically exhibits a patchy or clumped distribution with a scattering of live and dead trees. Characteristic is the presence of hardwood foliage to ground level. Scrubby oaks are a major feature of the habitat. Blackjack oaks are dominant in Oklahoma. Shin oak, Texas oak, and live oak are the dominant oaks in vireo habitats in Texas (Graber 1961; Grzybowski 1986; Grzybowski et al. 1994). Dense juniper stands typically are avoided. In the eastern parts of the range, preferred habitat often results from fire within stands of mature oak-juniper and remains suitable for 5 to 25 years after fire. In the arid western portions of the range, shrub habitats occupied by the vireo represent dimax conditions rather than early seral habitats (D. Diamond, professional communication). The best vireo habitats found by Marshall et al. (1985) were in 10- to 15-year-old burns that were hot enough to kill junipers. Data from some study sites indicated that there were significant differences with regard to the vegetation structure in territories held by first year males compared to those held by older males (Grzybowski et al. 1994). First year males tended to occupy areas that were more open floristically.

FORT HOOD: Black-capped vireo habitat at Fort Hood typically is shrubby, and ephemeral with a "clumped" vegetation structure. Most habitat patches were caused by accidental fires or mechanical clearing related to military training and operations. Sites are generally occupied by vireos from 4 to 25 years following disturbance. The most common tree/shrub species found in black-capped 
vireo habitat on F ort Hood were shin oak, flameleaf sumac, Ashe juniper, Texas oak, Skunkbush sumac, redbud, and Texas ash (Tazik et al. 1993b). Recent research suggests that tree/shrub species composition on vireo territories is variable, and that habitat structure (i.e., presence of low hardwood scrub) is a more critical factor in habitat selection than species composition (Tazik et al. 1993b).

Visual interpretation of aerial photography, known vireo locations, and ground surveys indicates 5319 ha of available or potential vireo habitat on Fort Hood (Table 2). This includes habitats in all stages of occupancy (sparse to dense), and all stages of successional growth (very young to $>25$ years old). Total estimated vireo habitat includes 2670 ha of warbler and vireo habitat burned in February 1996 that is anticipated to regenerate as suitable vireo habitat in the next 3 to 5 years.

Nest Site: The nest is open-cupped and pensile, about 5.8 to $6.2 \mathrm{~cm}$ in depth and $5.9 \mathrm{~cm}$ wide, and typically is located 0.5 to $1.5 \mathrm{~m}$ above ground (Graber 1961). In areas of oak-juniper habitat, nests consist largely of dried grass and leaves bound with spider web. Other materials may include plant fibers, cottony plant substances, paper, wool, and caterpillar silk. A variety of woody species common to the general habitat are used as nest substrates. As with the species composition of the general habitat, nest substrates vary geographically. Blackjack oak is the most frequently used species in Oklahoma while shin oak and Texas oak are frequently used in Texas (Graber 1961; Grzybowski 1986). J uniper and live oak are used but less than in proportion to availability (Grzybowski 1986).

FORT HOOD: Black-capped vireo nest sites on Fort Hood are characterized by dense hardwood scrub and sparse Ashe juniper at heights of 0-3 $\mathrm{m}$. A dense layer of vegetation occurs at $1.5-2.0 \mathrm{~m}$, just above average nest height (Melton et al., Unpublished). The area surrounding nests (within 5-m radius) has high levels of shin oak and Texas oak. Additionally, total woody cover, species density, and "clumpedness" of woody vegetation is greater in nest sites than nonnest sites. Favored nest substrates included Texas Oak, redbud, and shin oak. The average branch diameter at the nest was $4.5-4.8 \mathrm{~mm}$, regardless of the substrate species, and branch orientation of nests built over level (but not sloped) terrain was significantly biased toward the northeast.

Foraging Sites: The vireo is a foliage-gleaning insectivore that forages among the trees and shrubs in its habitat. It rarely feeds on the ground (Graber 1961). Foraging substrate preferences have not been quantified but may prefer deciduous substrates such as oaks (Grzybowski 1995). 
FORT HOOD: Little is known of the foraging substrates at Fort Hood, but low hardwood vegetation appears to be used (Tazik et al. 1993b). Vireos have also been observed foraging in taller junipers and oaks when tending fledglings.

\section{Food Resources}

Graber (1961) quantified the stomach contents of 11 black-capped vireos. Insect larvae constitute the bulk of the diet. Lepidopteran larvae predominate followed by Coleopteran Iarvae. Other animal matter includes spiders, centipedes, Neuroptera, Odonata, Hemi ptera, and Homoptera. The young are fed small larvae, with food items increasing in size as the young grow. Grasshoppers and other Orthopterans may contribute as much as one-third of their diet.

FORT HOOD: Dietary studies of the black-capped vireo have not been conducted at Fort Hood but diet is likely similar to that observed in other parts of the vireo's range.

\section{Known Population}

The known population consists of populations in Oklahoma, Texas, and Mexico. Grzybowski (1995) in his review of the species, cites data collected in 1990 to 1994 and reports three populations in Oklahoma: one had 20 - 30+ adults, in a second, 150 breeding females were documented, and a third consisted of a very small group of birds. He also cites reports of $<150$ adults in the Austin area of Texas (in 1989) and 450 adults in Kerr County, Texas (in 1990). Other sites in Texas contributed a count of 357 males at Fort Hood in 1997 (The Nature Conservancy 1998) and 12 males at Camp Bullis/Fort Sam Houston in 1997 (Weinberg 1998). The estimated population in Mexico is described in Benson and Benson (1990) and was based on 28 confirmed birds, which the authors extrapolated out to an estimate of 3,139 - 9463 pairs. See Scott and Garton (1991) and Benson and Benson (1991) for comments and details regarding the methods for the estimate.

The uncertainty of some estimates implores the need for formal surveys in less studied areas. The actual population may be much larger (Wahl, Biologist, Texas Parks and Wildlife Department, professional communication; Grzybowski, Professor, University of Oklahoma, professional communication).

FORT HOOD: The number of territorial male black-capped vireos documented on Fort Hood has risen from 85 in 1987 (Tazik 1991) to 357 in 1997 (The Nature Conservancy 1998). It has not yet been determined whether these data represent a true population increase or an increase in sampling intensity over time. 
Two estimates suggest that Fort Hood supports about 16 to 18 percent of the known population of black-capped vireos in Texas (Tazik 1991; USFWS 1996).

\section{Territory Size and Density}

Graber (1961) reported an average territory size of 1.5 ha. Mr. J im O'Donnell reported an average territory size of about 3 ha in Travis County, Texas (in Marshall et al. 1985). Graber (1961) also reported that the smallest breeding population she ever found consisted of five males and three females.

FORT HOOD: At Fort Hood, Tazik and Cornelius (1993) reported an average territory size of 3.6 ha, ranging from 1.9 to 7.0 ha. In contrast to Graber (1961), at Fort Hood there are regular observations of only one or two pairs at a given location. These isolated territories have been successful in fledging young.

Density estimates of black-capped vireos at seven study sites at Fort Hood showed that densities ranged from zero in one area abandoned by vireos to 0.41 singing males per ha (R. Melton, Biologist, ERDC/CERL, unpublished data). A comparison of these estimates between 1987 and 1995 suggested that density increased somewhat at four sites and decreased at three. Only the territory decreases were statistically significant. A dramatic decline in density at one of those sites was to be expected since the vegetation had succeeded beyond stages favored by the black-capped vireo. An installation-wide population increase may have occurred, but has not yet been statistically confirmed.

Excluding the site that was older than the seral stage preferred by vireos, the average annual density estimate for the six sites combined ranged between 0.18 $\mathrm{males} / \mathrm{ha}$ and $0.30 \mathrm{males} / \mathrm{ha}$ (1988 =0.19 males/ha, $1989=0.18 \mathrm{males} / \mathrm{ha}, 1991=$ $0.30 \mathrm{males} / \mathrm{ha}, 1992=0.29 \mathrm{males} / \mathrm{ha}, 1993=0.25 \mathrm{males} / \mathrm{ha}, 1994=0.22$ males/ha, $1995=0.24$ males/ha).

\section{Survival}

Graber (1961) found that 69 percent of the males that she banded returned the following year, but that only 41 percent of females returned. Grzybowski (1990) reported a similar difference between sexes; 65 percent for males versus 41 percent for females in main colony sites in Texas. One-year returns in the Wichita Mountains of Oklahoma were 62 percent for males and 44 percent for females (Grzybowski 1989a). The difference between sexes may be due to several factors: greater inconspicuousness of females compared to males, less site tenacity on the part of females, or a real difference in survivorship between the sexes. Lower survivorship among female songbirds has been reported by others (Nice 1937; 
Stewart and Aldrich 1951; Nolan 1978). J uvenile survivorship is at least 24 percent (Grzybowski 1995) but may be in the range of 35 to 55 percent (Grzybowski and Pease, Professor, University of Texas, professional communication). Grzybowski (1995) indicates that 96 percent of the males greater than 1 year old were site faithful, while many yearling males exhibited less site tenacity and a greater degree of dispersal or wandering. Gryzbowski (1990) found return rates in small "satellite" populations to be lower than those in main "colonies." This might be due to differences in site tenacity more so than differences in survivorship between the two population types.

FORT HOOD: Tazik (1991) reported an overall observed return rate at Fort Hood of 53.5 percent for males and 42.9 percent for females, although there was much between-year variation. Similar to Grzybowski's finding, Tazik (1991) also reported return rates for males in peripheral populations on Fort Hood were notably lower than were those at main colony sites (31.3 versus 57.3 percent).

\section{Reproductive Biology}

Within a breeding season, black-capped vireos are monogamous or sequentially polygamous (Grzybowski 1995). Individual pairs establish breeding territories. The nest cycle includes construction (4-5 days), inactive construction (1 day), laying (4 days), incubation (14-17 days beginning after the second or third egg laid), brooding of nestlings (11 days), and fledgling (40+ days) (Graber 1961). The male is involved in all stages of the nesting cycle. Both sexes participate in nest building although the female performs more of the construction as the male often pauses to sing and defend the territory (Graber 1961). The male conducts about one-third of the incubation. U pon hatching, the chicks are brooded by the female while the male furnishes about 75 percent of the food for the young. Pairs frequently renest after both successful and unsuccessful nest attempts.

Reproductive success reportedly has been poor throughout the range of the vireo due largely to the impact of brown-headed cowbird brood parasitism (Graber 1961; Grzybowski 1995; Grzybowski et al. 1986; Grzybowski 1988, 1989b, 1990). In one example, Graber (1961) observed a sample of 76 nests containing a total of 243 eggs. Only 17.6 percent (43 eggs) produced fledglings. Of the 134 eggs lost prior to hatching, 72.3 percent were lost to cowbird activity. Only 9 percent of eggs were lost to predators. Among the 95 eggs that hatched young, 26.3 percent were lost due to the presence of cowbird young in the nest, while 16.8 percent were lost to predators. In all, 19.7 percent (15 of 76) of nests in which eggs were laid and 59.7 percent of mated pairs (46 of 77) were successful in fledgling at least 1 vireo. A total of 43 young were fledged for an average production of 0.56 young per pair per year. In another example, Grzybowski (1990) reported pro- 
duction of 0.92 to 2.58 young per pair in areas with cowbird removal and 0 to 0.38 young per pair in areas without cowbird removal during 1988. During 1989, production was 2.00 to 3.78 in removal areas compared to 1.27 to 1.44 in nonremoval areas. In Oklahoma, production was 1.37 with cowbird removal, 0.36 without removal (Grzybowski 1990). Other productivity reports include 0.82 to 1.76 on three areas managed by the Texas Parks and Wildlife Department (Bryan and Stuart 1990), and an average of 1.0 to 1.4 young per pair per year (with cowbird egg removal) at Fort Sill, Oklahoma, during the period 1988 through 1990.

FORT HOOD: At Fort Hood, black-capped vireos appear to be primarily monogamous; however, sequential polygamy has been commonly observed.

Nest parasitism by cowbirds has been severe at times on Fort Hood, particularly in the initial years of the monitoring program. Mitigation of that phenomenon has been an integral component of the management strategy and nest parasitism rates at Fort Hood have dropped dramatically. In 1987 and 1988 nest parasitism rates were about 90 percent. In 1993, 1994, and 1995 those rates dropped to $25.8,12.8$, and 15.2 percent, respectively. Nest success rates mirrored those trends. In 1987 and 1988, nest success rates were less than 5 percent, while they were between 32.7 and 55.6 percent during the period 1993-1995 (Weinberg et al. 1998). The increase in nest success was attributed to aggressive cowbird trapping and shooting efforts conducted by Fort Hood biologists. During 1987 to 1994, a significant association existed between declining nest parasitism and increasing nest success rates as well as between decreasing nest parasitism rates and the number of cowbirds destroyed (Hayden et al. 2000). It is likely that there would be little successful nesting without cowbird control.

Monitoring at study sites at Fort Hood has revealed a pattern of seasonality in nest parasitism. While 48.7 percent of the vireo nests were initiated during April, only 5.9 percent were parasitized during that period. The vast majority of parasitism events (82.4 percent) occurred between May 1 and J une 10, when only 45.5 percent of the vireo nests were initiated (Weinberg et al. 1998). This apparent "parasitism-free period" in April is concordant with the possibility that the cowbirds breeding period coincides with the period of greatest host nest density (see Robinson et al. 1995). This is supported by Barber and Martin's (1997) finding that the incidence of nest parasitism in black-capped vireo nests on Fort Hood was correlated with the cumulative density of alternative hosts. 


\section{Interactions With Other Species}

Habitat Associates: The black-capped vireo coexists with a wide variety of other species within its habitat. The particular composition of associated species differs somewhat geographically (Graber 1961).

FORT HOOD: Some characteristic associates of the black-capped vireo on Fort Hood include northern cardinal, tufted titmouse, blue-gray gnatcatcher, whiteeyed vireo, northern mockingbird, yellow-breasted chat, brown-headed cowbird, painted bunting, rufous-crowned sparrow, field sparrow, and Bewick's wren.

Competition: Territories of the black-capped vireo sometimes overlap with that of the white-eyed vireo or Bell's vireo. No direct competition with other species was observed by Graber (1961).

FORT HOOD: At Fort Hood, a black-capped vireo was observed chasing a white-eyed vireo (J . Cornelius, Biologist, Fort Hood, TX, professional communication). Field workers suspect competition between the two species, but have not yet confirmed it.

Depredation: Direct depredation on adult birds has rarely been observed.

FORT HOOD: Depredation on adult vireos has not been studied at Fort Hood. Its occurrence is thought to be rare. Current studies of depredation using video cameras at nests have documented depredation by cowbirds, fox, snakes, scrub jay, and rat.

DISEASE: The species is unusually free of ectoparasites and disease (Graber 1961).

FORT HOOD: Studies of disease and ectoparasities have not been conducted on the black-capped vireo on F ort Hood.

\section{Threats to Survival}

Major threats to the continued existence of the black-capped vireo include (1) loss of habitat due to urban development, excessive rangeland improvement, grazing by sheep, goats, and exotic herbivores, and natural succession including juniper invasion; and (2) cowbird brood parasitism (Grzybowski 1995, Shull 1986, Ratzlaff 1987). The black-capped vireo recovery plan (USFWS 1991) and the 1995 Population Viability and Habitat Analysis (PVHA) Workshop Report (USFWS 1996) document regional threats to survival. 
FORT HOOD: At Fort Hood, the primary threats to the black-capped vireo are brood parasitism, habitat loss and degradation, and fire suppression. 


\section{Croton alabamensis (Texabama croton)}

No federally endangered or threatened plant species are known to occur on Fort Hood. The Alabama croton (Croton al abamensis var. al abamensis) is a species of concern that was formerly a category 2 candidate for Federal listing. This species was formerly known from only two counties in Alabama and one county in Tennessee. In 1989 a variety of C. alabamensis was discovered on Fort Hood. This variety has subsequently been described and designated as $C$. alabamensis var. texensis (Ginzbarg 1992). It is sometimes known by the unofficial common name of Texabama croton.

\section{Nomenclature and Classification}

Scientific Name: Croton al abamensis var. texensis

Family: Euphorbiacae

Original Description: Ginzbarg 1992

Type Specimen: Gainer Ranch, Travis County, Texas (Ginzbarg 1992).

Current Federal Status: Species of Concern

\section{History of the Taxon}

Alabama: C. alabamensis was first noticed by E.A. Smith in 1877 (McDaniel 1981), and has since been described as one of the rarest shrubs in the United States (Farmer and Thomas 1969). Habitat information and the original description were published in Mohr (1889). Dr. J oe Allen Farmer published a dissertation on the species in 1962 . The Alabama variety of this taxon presently is listed as a category 2 candidate species for F ederal listing.

TEXAS AND FORT HOOD: In 1989, a disjunct population of this species was discovered on Fort Hood Military Reservation by J ohn Cornelius, a Fort Hood installation wildlife biologist. Other Texas populations have subsequently been discovered in Travis and Coryell counties. After taxonomic review, the Texas population of this species was designated a new variety, C. alabamensis texensis (Ginzbarg 1992). Studies of the Fort Hood population have been conducted under the direction of Dr. Robert Shaw of Colorado State University (Aplet et al. 1991).

\section{Description}

TEXAS AND FORT HOOD: A technical description of the Texas variety of C. alabamensis is given in Ginzbarg, 1992. In most respects, the appearance of the Texas variety is very similar to the Alabama variety (described in Kral 1983). 
There are distinct differences in coloration of scales on the underside of the leaves and stems. The Texabama croton has copper-colored scale surfaces, and some scales have dark reddish-brown centers. In contrast, the Alabama variety has silver scale surfaces and scales lack dark centers.

The Texabama croton is a monoecious shrub 2-3 $\mathrm{m}$ tall with many branches emerging from the base. Lower branches sometimes take root and stems have thin gray bark, which gives a slightly sweet odor when scratched. Stems are leafy only near their tips and new growth is angular. Leaves are alternate, exstipulate; petioles 0.6-1.9 mm long, canaliculate; blades ovate or elliptic, 3.8-9.0 $\mathrm{cm}$ long, 1.5-4.0 cm wide, entire; apex acute, rounded or emarginate; base obtuse to slightly cordate, glandless; upper surface dark green with scattered scales. The inflorescence is a terminal 6-14 flowered raceme, 1.9-3.3 cm long with pistillate flowers near the base and staminate flowers above (Ginzbarg 1992).

\section{Geographic Distribution and Known Population}

Alabama: Prior to its discovery in Texas, C. alabamensis was known only from Tuscaloosa and Bibb Counties in Alabama and Coffee County in Tennessee (Ginzbarg 1992). In Alabama, the species is restricted to two major population centers. Individual populations consist of a few to many individuals covering several acres (Kral 1983). At the time of Farmer's work (1962), the species covered no more than about 40 ha.

TEXAS AND FORT HOOD: The Texas variety has been observed only in Coryell and Travis Counties. In Travis County, the plants occur mostly in deciduous forest in mesic limestone canyons and on slopes. The major known populations in Travis County are on the Gainer Ranch (500-1,000 plants) and the Penn Ranch (several thousand individuals) (Ginzbarg 1992).

In Coryell County, the Texas variety is known only from F ort Hood. Both significant populations on Fort Hood occur in protected canyons along the Owl Creek river drainage in TAs 2 and 3A (Aplet et al. 1991). The largest population, consisting of several thousand individuals, occurs in TA 2 (Ginzbarg 1992). Several scattered plants and a small population have been found between and around these two populations near tributaries to Owl Creek (Aplet et al. 1991). The total population on Fort Hood is estimated to be around 20,000 individuals (Aplet et al. 1991). 


\section{Habitat}

Alabama: There are pronounced differences between the habitats of the two croton varieties. The Alabama variety occurs on shallow soils and rock outcrops at mid-slope positions, and occurs in areas with intense drought and high soil and air temperatures. The croton groves in Alabama have few or no large trees, are dominated by shrubs, and have relatively few herbs (F armer 1962).

TEXAS AND FORT HOOD: The Texas variety grows on shallow, moderately alkaline, gravelly or stony clay or clay-loam overlying Cretaceous limestone (Ginzbarg 1992). This variety forms dense local thickets as understory shrubs in mesic canyon hardwood forests or in full sun. The bark is thin and apparently this species is not fire tolerant. Thus, it is generally confined to more mesic areas near streamsides in canyons that provide some protection from fire.

Aplet et al. (1991) report that on Fort Hood, this croton variety grows in deep soils on toe slopes and fluvial deposits of canyon bottoms and is thus a drought avoider. They indicate that its occurrence exhibits no association with overstory gaps, disturbance, or particular fluvial geomorphic features. It appears to be restricted to canyon bottoms characterized by mesic conditions provided by the presence of overstory cover and a number of other species. Steeper stream gradients may produce microhabitat that is not conducive to establishment and growth.

\section{Reproductive Biology}

Alabama: The reproductive biology of the Alabama variety was evaluated by Farmer (1962). He observed no evidence of asexual reproduction, although the species has been propagated by stem cuttings. In nature, plants require 5 to 7 years growth prior to onset of sexual reproduction. Flower buds are produced in May or J une and overwinter before flowering in mid-March. Plants are selffertile, with pistillate flowers often most numerous toward the bottom of the plant. Wind is the primary pollination agent. Fruits develop by mid-May. Seeds are dispersed up to about $7 \mathrm{~m}$ from the parent by a catapulting mechanism. A heavy seed crop is produced each year, much of it lost to rodents, birds, and possibly ants. Partial shade can reduce seed production by 10 to 50 percent. Forest cover can reduce it by 75 to 95 percent. Seeds, which require cold stratification, are dormant until germination takes place in February or March.

TEXAS AND FORT HOOD: Relatively little has been published about the reproductive biology of the Texas variety. Ginzbarg (1992) reports that it flowers from February - March, sets fruit in May, and fruits have dehisced by early J une. 
In contrast to the Alabama variety, A plet et al. (1991) reported good evidence of asexual reproduction. This involved the production of "new upright shoots through the nodal rooting (layering) of prostrate branches."

\section{Survival and Growth}

Alabama: The survival and growth in the Alabama variety have been fairly well studied. Seed survival is probably very low, perhaps 1 percent of seed production (Farmer 1962). Seedling mortality may be quite high as well. In experimental populations, Farmer (1962) reported 20 percent survival to 2 years. Clonal stands are all-aged and consist of individuals as old as 21 years (Farmer 1962). Following germination, seedlings grow until dormancy begins in J une in Alabama (Farmer 1962). Most consistent plant growth occurs during March and April. More erratic growth occurs during periods of high moisture. Leaves turn yellow by mid-J une. Growth of primary roots is restricted largely to the first 2 centimeters, with the remainder of root growth within $15 \mathrm{~cm}$ even on deeper soils.

TEXAS AND FORT HOOD: Aplet et al. (1991) reported that all size and age classes of the Texas variety are well represented on Fort Hood, indicating a healthy population of adults, juveniles, and new recruits. Little else has been reported about the survival and growth of the Texas variety.

\section{Interactions with Other Species}

Alabama: Other plant species characteristically found in association with the Alabama variety include Golden St. J ohnswort, Skunkbush sumac, and Red cedar with sumac usually most abundant (Farmer 1962). Seeds are thought to be utilized by various rodents, birds, and perhaps ants (F armer 1962).

TEXAS AND FORT HOOD: On Fort Hood, species associated with the Texabama croton occur in the Texas Oak Series mesic limestone canyon forest community (Diamond 1992; Ginzbarg 1992). There is some indication that high cover of Texas ashe and Chinquapin oak indicates a good site for this croton variety (Aplet et al. 1991).

The dominant plant species observed where this variety is found on Fort Hood include Ashe juniper (accounting for 53.6 percent of total cover), Texas ashe (24.1 percent), Texas oak (23.7 percent), and a grape species (15.9 percent). Other relatively common species include Chinquapin oak (9.8 percent), Indian-cherry buckthorn (7.4 percent), Deciduous holly (7.2 percent), Cedar elm (6.1 percent), a walnut species (4.1 percent), and Lowland hackberry (3.04 percent) (Aplet et al. 
1991). Within the two canyons in which it occurred, understory cover of the Texabama croton averaged 10.4 percent (Aplet et al. 1991). 


\section{Cave-adapted Fauna}

Troglobite and troglophile faunal communities of Texas (cave-adapted or cavedependent organisms) are often represented by rare endemics due to the narrow ecological niche and natural isolation of the cave systems they inhabit. The objective of this ESMP is to provide adequate protective measures to avoid listing cave-adapted species found on Fort Hood under the ESA. Several endemic and currently undescribed cave invertebrate species and one probable new species of salamander occur on Fort Hood. Many of these species could be proposed for listing as endangered in the future. Rare or endemic species known to occur on Fort Hood are listed in Table 3. Tables 4 and 5 show status of biological collections in surveyed (interior dimensions mapped) and unsurveyed caves. A report is currently in preparation summarizing location and structure of each cave and karst feature known on Fort Hood and taxonomic status of biological collections.

Specimens of the probable new salamander species have been collected from three caves in the northeast training ranges of Fort Hood. These new specimens are currently undergoing taxonomic review to determine species status.

Cave invertebrates typically are found in moist caves with constant humidity and temperature (USFWS 1994). Caves occupied by endangered invertebrates in Travis and Williamson Counties, Texas, are small and as shallow as 3 meters. Species associated with these caves were listed primarily to mitigate threats due to increasing urbanization. The largest has only $60 \mathrm{~m}$ of passage (Chambers and J ahrsdoerfer 1988). The cave fauna depends on ground water infiltration. If caves become dry during certain periods of the year, the resident fauna may retreat to deeper parts of the system. Troglobites are entirely dependent upon surface organisms for their energy and nutrients (USFWS 1994). Fort Hood has numerous cave and karst features, and the associated invertebrates are vulnerable to military activities.

Cave invertebrates as well as other cavedwelling species may face several threats from military and recreational activities on Fort Hood. The Endangered Karst Invertebrates Recovery PIan (USFWS 1994) describes a number of general threats to cave invertebrates. These include the following:

- Urban development activities.

- Filling in and collapsing of caves.

- Alteration of drainage patterns.

- Alteration of surface plant and animal communities.

- Contamination.

- Human visitation, vandalism, and dumping. 
- Fire ants.

- Mining, quarrying, or blasting above/in caves.

These factors affect cave invertebrates by increasing sedimentation, reducing food availability, and altering environmental conditions within the cave. On Fort Hood, military activities could potentially contribute to the filling in and collapsing of caves, alteration of surface plant and animal communities, contamination, dumping, and blasting above caves. Additionally, civilian visitors to caves could negatively impact cave invertebrates. Red imported fire ants are abundant on Fort Hood and could pose a threat. 


\section{Other Species}

Additional listed and candidate species occur either as accidental or as transients on Fort Hood (Table 1). For some of these species detailed management plans are not warranted at this time due to infrequent, transient occurrence on the installation. Only species discussed briefly below are considered further in this ESMP.

\section{Bald Eagle}

The bald eagle has been recorded during winters at Belton Lake on or adjacent to Fort Hood (J . Cornelius, Biologist, Fort Hood, TX, professional communication). The bald eagle does not nest on the installation.

\section{Whooping Crane}

The whooping crane also is a rare migrant. Five whooping cranes were sighted in TA 15 during December 1986. They may fly over or near Fort Hood during spring (1 to 20 April) and fall (1 to 20 October) migration (Diersing et al. 1985). They may stop at Belton Lake during migration.

\section{Peregrine Falcon}

Anecdotal observations of peregrine falcons have been recorded on Fort Hood. Peregrine falcons do not nest on the installation and observations are likely transitory migrants. 


\section{ESMP Objectives}

Preface: Accomplishment of the following objectives and accompanying conservation actions are contingent upon availability of funding and personnel resources. One purpose of this ESMP is to identify necessary personnel and funding requirements to meet ESMP objectives. At the present time it is anticipated that adequate personnel and funding will be available to accomplish prescribed actions under this ESMP. If prescribed actions under this ESMP cannot be accomplished due to personnel or funding shortfalls, Fort Hood will enter consultation with the USFWS to determine potential impacts on the installation's training mission and the following conservation objectives for endangered species on Fort Hood.

\section{All Species}

\section{Compliance}

Regardless of habitat designation on Training Area maps, the Army will comply with all applicable sections of the Endangered Species Act (1973, as amended) for all training, operations, maintenance, and construction activities conducted on Fort Hood.

Implement installation fire management and protection policies (Appendix B).

\section{Protection}

Maintain and distribute Training Area maps with overlay of areas subject to F ort Hood Endangered Species Training Guidelines (Figure 8 and Appendix C). 


\section{Golden-cheeked Warbler}

\section{Population Goal}

Maintain sufficient habitat to support a minimum carrying capacity of 2000 singing males.

\section{Protection}

Implement training restrictions in designated "core" habitats in accordance with Fort Hood Endangered Species Training Guidelines (Appendix C).

Reduce training restrictions in designated "non-core" habitats consistent with essential mission requirements.

Implement a sustainable incidental take limit for the 5-year term of this ESMP.

\section{Management}

Maintain currently available habitat consistent with population carrying capacity goal and essential mission requirements.

\section{Monitoring}

Document golden-cheeked warbler population trend.

Assess population status by monitoring demographic parameters.

\section{Research}

Refine and validate population viability models for golden-cheeked warblers on Fort Hood.

Evaluate relationship of habitat quality and golden-cheeked warbler abundance and productivity.

Evaluate fire-related dispersal patterns of golden-cheeked warblers.

Evaluate effects of recreational off-road vehicle (motorized and nonmotorized) use on golden-cheeked warbler demography and productivity. 


\section{Black-capped Vireo}

\section{Population Goal}

Maintain sufficient habitat to support a minimum carrying capacity of 1000 singing males.

\section{Protection}

Implement training restrictions in designated "core" habitats in accordance with Fort Hood Endangered Species Training Guidelines (Appendix C).

Reduce training restrictions in designated "non-core" habitats consistent with essential mission requirements.

Implement a sustainable incidental take limit for the 5-year term of this ESMP.

\section{Management}

Maintain sufficient habitat to meet population carrying capacity goal in seral stage suitable for occupation by black-capped vireos.

Maintain parasitism of vireo nests by brown-headed cowbirds below an average of 10 percent annually in non-live-fire training areas during the 5-year term of this ESMP.

\section{Monitoring}

Document black-capped vireo population trend.

Assess population status by monitoring demographic parameters.

\section{Research}

Refine and validate population viability models for black-capped vireos on Fort Hood.

Determine predator types and effects of depredation on black-capped vireo nests.

Evaluate effects of recreational off-road vehicle (motorized and nonmotorized) use on black-capped vireo site fidelity and habitat use. 


\section{Croton alabamensis (Texabama croton)}

\section{Protection}

Protect known locations from human-related disturbance.

\section{Monitoring}

Monitor status and distribution of populations. 


\section{Cave-adapted Fauna}

\section{Protection}

Protect sensitive cave and karst features from human-related risk factors identified in the Endangered Karst I nvertebrates Recovery PIan (USFWS 1994).

\section{Monitoring}

Monitor changes in representative samples of endemic cave fauna and species listed or proposed for listing in the future.

Locate, map, and conduct biological collections in sensitive cave and karst features on Fort Hood.

\section{Research}

Complete taxonomic evaluation and description of undescribed material collected from F ort Hood caves.

Complete taxonomic evaluation of the undescribed salamander first collected in 1992.

Determine impact of fire ants on cave-adapted fauna. 


\section{Other Species}

\section{Protection}

Bald Eagle: Minimize disturbance from low-level helicopter flights and other aviation assets.

Whooping Crane: If whooping cranes are observed, protect from potential disturbance from military training and other land use activities.

Peregrine Falcon: If peregrine fal cons are observed, monitor presence for potential disturbance from human activity.

\section{Monitoring}

Conduct additional surveys to determine presence and status of other listed, rare, and sensitive species. 


\section{Conservation Actions: All Federally Listed Species}

\section{Compliance}

Objective

Regardless of habitat designation on Training Area maps, the Army will comply with all applicable sections of the Endangered Species Act (1973, as amended) for all training, operations, maintenance, and construction activities conducted on Fort Hood.

\section{Objective J ustification}

This ESMP does not supersede the legal obligation of the Army and Fort Hood to comply with Federal law as set forth in the Endangered Species Act (1973, as amended).

\section{Conservation Actions}

As required by Section 7 of the Endangered Species Act, the Army and Fort Hood will assess the effect of any proposed activity on any listed species or its habitat occurring in the project area. Fort Hood has conducted a biological assessment for the current ongoing mission and the USFWS has issued a Biological Opinion (September 1993, revised J uly 2000) that provides conditions for the continuance of mission activities on Fort Hood. Fort Hood currently is in compliance with conditions of the 2000 Biological Opinion. Any future actions including construction or significant changes in training activity will still be subject to Section 7 consultation requirements. Some areas on F ort Hood are subject to training re strictions under the Fort Hood Endangered Species Training Guidelines (Appendix C) due to the presence of listed species and are designated on Fort Hood Training Area maps. Areas not subject to training restrictions under the Fort Hood Training Guidelines are still subject to all Section 7 compliance requirements. 
Any construction, project, or training activity on Fort Hood that may result in permanent loss of endangered species habitat will require consultation with USFWS in accordance with Section 7 requirements. Incidental take as defined under this ESMP is limited to habitat loss from transient training activities in "non-core habitats" and fire in all habitat designations.

Objective

Implement installation firemanagement and protection policies (Appendix B).

\section{Objective J ustification}

Extensive wildfires in during February 1996 burned 2728 ha of endangered species habitat, exceeding allowable take under the USFWS Biological Opinion in effect at that time. As a result of these fires, in consultation with USFWS, Fort Hood updated and revised its fire management and control policies, and implemented efforts to evaluate effects of the fires on endangered species and habitats on the installation. Conservation actions under this objective will significantly reduce the risk of future occurrence of similar fire events. These actions are necessary to ensure maintenance of population goals established under this ESMP and reduce risk of increased training restrictions as a result of exceeding allowable take.

\section{Conservation Actions}

Conservation actions are those actions detailed in Fort Hood's fire management policy including development of a fire break plan for the installation (Appendix B).

\section{Protection}

Objective

Maintain and distribute Training Area maps with overlay of areas subject to Fort Hood Endangered Species Training Guidelines (Figure 8, Appendix C).

\section{Objective J ustification}

Soldiers performing field training must have access to current maps showing designated restricted areas in order to comply with requirements of the Fort Hood Endangered Species Training Guidelines (Appendix C). Conservation ac- 
tions to meet this objective will ensure to the extent possible that all soldiers and commanders on Fort Hood have access to current information on the location of restricted areas.

\section{Conservation Actions}

Training Area maps will be revised to show areas in the maneuver training ranges subject to conditions of the Fort Hood Endangered Species Training Guidelines in accordance with habitat designations established under this ESMP. Areas subject to the Endangered Species Training Guidelines on maneuver training areas will be labeled as "Training Restricted Zones" on training area maps.

The overlay for all endangered species habitats within the Live-fire Training Areas (TAs 61 through 94) will be labeled as "Burn Protection Zones." No maneuver training is conducted within the Live-fire Training Areas so most training restrictions listed under Appendix $C$ are not relevant in the Live-fire Training Areas. The only training restrictions listed in Appendix $C$ that are relevant within the Live-fire Training Areas are those related to use of incendiary devices and those policies implemented under Appendix B. Labeling T\&E habitats within the Live-Fire Training Areas as "Burn Protection Zones" focuses installation attention on the importance of implementing fire prevention and mitigation policies in these areas.

Revised Training Area maps will be issued or available to all applicable installation commands and training support elements. All earlier editions will be collected and destroyed to the extent possible.

Training Area maps will be revised every 5 years concurrent with the 5 -year revision of this ESMP to incorporate any changes in designated habitats subject to training restrictions. 


\section{Conservation Actions: Golden-cheeked Warbler}

\section{Population Goal}

Objective

Maintain sufficient habitat to support a minimum carrying capacity of 2000 singing males

\section{Objective J ustification}

Current population viability analyses (PVA) (Appendix D) indicate that habitat carrying capacity lower than that necessary to support a maximum of 1000 singing males of golden-cheeked warblers greatly increases the probability of extinction. As shown in Figure 6, increasing carrying capacities above 1000 singing males does not significantly alter the probability of extinction. Carrying capacity represents the maximum potential of the habitat to support singing males. Carrying capacity does not necessarily reflect the number of singing males normally expected to occur (Figure 7). However, as shown in Figure 7, increases in carrying capacity above 1000 singing males does increase the expected number of singing males present. Maintaining carrying capacity in excess of 1000 singing males also provides some buffer in the event of catastrophic loss of habitat or birds. A carrying capacity of 2000 exceeds the threshold for increased extinction risk and provides capacity for the presence of substantial numbers of singing males in excess of current USFWS recovery goals.

\section{Conservation Actions}

Current PVA (population viability analysis, Appendix D and Table 2) indicates a minimum of 8520 ha of habitat comparable to that occurring in $13 \mathrm{~B}$ is necessary to provide a carrying capacity for 2000 singing males. Current estimate of available habitat on Fort Hood is 21,496 ha. Under current assumptions and parameter estimates of the PVA (Appendix D), enough habitat currently exists on Fort Hood to meet this objective. The Conservation Action to meet this objective will be to minimize any loss of warbler habitat on Fort Hood due to fire, training, 
or other habitat altering activities in accordance with protection and management objectives established under this ESMP.

\section{Protection}

Objective

Implement training restrictions in designated "core" habitats in accordance with Fort Hood Endangered Species Training Guidelines (Appendix C).

\section{Objective J ustification}

Military training in areas occupied by golden-cheeked warblers can destroy habitat and disturb individuals, potentially resulting in reduced abundance and productivity. These impacts increase the possibility of "take" as defined in the ESA. The Fort Hood Biological Opinion (September 1993) states that implementation of the Fort Hood Training Guidelines in endangered species habitat is sufficient to avoid take of black-capped vireo and golden-cheeked warbler habitats due to military training activities. Implementation of the Fort Hood Training Guidelines in the areas designated in this plan meets population goals for carrying capacity under this ESMP. "Core" habitat areas designated under this objective were selected based on known population distributions, quality and contiguity of habitat, and minimal mission conflicts.

\section{Conservation Actions}

Implement Fort Hood Endangered Species Training Guidelines for 14,879 ha of golden-cheeked warbler habitat designated as "core" habitats (Table 2 and Figure 8). "Core" habitat areas within live-fire areas will be designated as "Burn Protection Zones." Areas in maneuver training areas will be designated as "Training Restricted Zones."

\section{Objective}

Reduce training restrictions in designated "non-core" habitats consistent with essential mission requirements.

\section{Objective J ustification}

The 14,879 ha designated as "core" golden-cheeked warbler habitat protected under the Fort Hood Endangered Species Training Guidelines exceeds the cur- 
rent estimate of habitat ( $8520 \mathrm{ha}$ ) necessary to achieve a population carrying capacity goal of 2000 singing males. Total warbler habitat on Fort Hood (21,496 ha) exceeds the habitat area designated as "core" habitat. Protection of "noncore" habitat will be in accordance with incidental take limits and mitigation requirements as described under the following objective for establishing incidental take limits. Designation of areas as "non-core" habitat is based on essential mission training requirements and does not imply any qualitative difference between "core" and "non-core" habitat with regard to suitability as golden-cheeked warbler habitat. Designation of warbler habitat as "core" or "non-core" is related only to training activities allowed under these respective designations.

\section{Conservation Actions}

Training restrictions under the Fort Hood Endangered Species Training Guidelines will be rescinded for 6617 ha of golden-cheeked warbler habitat identified in Figure 4.

The Fort Hood Natural Resources Branch will maintain records and maps of all areas occupied by endangered species regardless of protected status under the Fort Hood Endangered Species Training Guidelines.

"Non-core" habitat areas will remain subject to all other applicable Fort Hood range regulations, in particular regulations governing activities that could result in permanent alteration to endangered species habitat. An example would be the requirement to submit for approval Excavation Permit \#420-X10 prior to initiating any excavation activities on the installation.

\section{Objective}

Implement a sustainableincidental take limit for the 5-year term of this ESMP.

\section{J ustification}

The intent of this ESMP is to promote recovery of endangered species on Fort Hood lands while permitting the military maximum flexibility to perform mission essential tasks. Current estimates of available golden-cheeked warbler habitat on Fort Hood exceed population and recovery goals under this ESMP. Implementation of incidental take limits provides flexibility for conducting mission activities that may result in habitat loss. However, this potential habitat loss is limited so as not to jeopardize baseline habitat requirements and to provide an adequate habitat mitigation bank in perpetuity without implementing further restrictive measures on the military mission. 
Habitat "Ioss" as defined under this ESMP is any permanent or temporary alteration of currently suitable habitat to the extent that it is unsuitable for occupation by breeding adults. Mitigation requirements described below for habitat loss exceeding incidental take limits provide F ort Hood an incentive to carefully consider any permanent alteration or excessive loss of endangered species habitats.

\section{Conservation Actions}

Fort Hood will implement an incidental take limit of 519 ha of golden-cheeked warbler habitat during the 5-year term of this ESMP. Incidental take provided under this ESMP will be limited to those military activities associated with transient training activities in habitats not subject to the Fort Hood Endangered Species Training Guidelines and loss due to uncontrolled burns in all habitat areas. Proposed projects and land use actions that will permanently alter endangered species habitats are subject to Section 7 requirements of the ESA. This incidental take will not apply to any proposed project or training action determined to permanently alter endangered species habitats. Such activities will require Fort Hood to initiate Section 7 consultation with the USFWS prior to implementation. Specific incidental take thresholds and required actions for habitat loss during the 5-year term of this ESMP are described below.

\begin{tabular}{|l|l|}
\hline Habitat loss (hectares) & Action Required \\
\hline $0-519$ & $\begin{array}{l}\text { No action required for loss due to transient training activities in areas not } \\
\text { subject to the Fort Hood Endangered Species Training Guidelines (i.e., } \\
\text { Non-Core Habitat) and loss due to fire in all habitat areas. Report annu- } \\
\text { ally to USFWS as part of regular reporting requirement. }\end{array}$ \\
& $\begin{array}{l}\text { Loss due to proposed construction activities or other permanent takings } \\
\text { requires Section } 7 \text { consultation. }\end{array}$ \\
& $\begin{array}{l}\text { Loss due to training activities in areas subject to the Fort Hood Endan- } \\
\text { gered Species Training Guidelines (i.e., "Core" Habitat) requires Section } 7 \\
\text { consultation. }\end{array}$ \\
\hline $\begin{array}{l}\text { Incidental take under the Incidental Take Statement and Fort Hood's } \\
\text { ESMP is exceeded. Requires Section 7 consultation with USFWS. Im- } \\
\text { plement Endangered Species Training Guidelines on habitat at a 4:1 ratio } \\
\text { of protected habitat / habitat loss. Habitat designated as "core" in excess } \\
\text { of the } 8520 \text { ha carrying capacity objective provides pre-mitigation for habi- } \\
\text { tat loss exceeding the incidental take limit. }\end{array}$ \\
\hline
\end{tabular}


The incidental take limit for golden-cheeked warbler habitat is based on three criteria:

1. Available habitat in excess of the 8520 ha necessary to meet ESMP carrying capacity objectives provides a mitigation bank for habitat loss at a 4:1 ratio.

2. Incidental take limit for the 5-year term of this ESMP is based on a renewable 25-year regeneration cycle for warbler habitat.

3. As long as habitat loss remains within incidental take limits, no additional protective measures are required.

Under the first criterion, available habitat of 21,496 ha (Table 2) on Fort Hood exceeds the estimated baseline requirement ( $8520 \mathrm{ha}$ ) necessary to meet population carrying capacity goals by 12,976 ha. At a $4: 1$ mitigation ratio, the current 12,976 ha of habitat in excess of the baseline requirement provides a mitigation bank for a potential habitat loss totaling no more than 2595 ha.

Based on the second criterion that warbler habitat has an approximate regeneration cycle of 25 years, a prorated loss rate of 519 ha per 5-year period would maintain baseline habitat requirements with no net loss in habitat currently available for mitigation in excess of the baseline habitat requirement. At this loss rate, the total amount of habitat loss at any point in time would never exceed 2595 ha due to regeneration of disturbed habitats on a 25-year cycle. Therefore, sufficient habitat would be maintained in excess of the baseline requirement to mitigate at a 4:1 ratio for this rate of habitat loss.

The third criterion is based on the adequacy of available habitat to provide a mitigation bank without implementing additional protective measures for habitat loss not exceeding 519 ha during the 5-year term of this ESMP. Habitat loss exceeding the incidental take limit of 519 ha will require Section 7 consultation and requires designation as "core" habitat at a 4:1 mitigation ratio. The 6359 ha designated as core habitat above the 8520 ha necessary to meet carrying capacity goals, provides this mitigation for 1272 ha $(254$ ha per 5-year period, prorated for 25 year renewal cycle) of habitat loss above the incidental take limit and would not cause realignment of initial "core" habitat designations under this ESMP. Mitigation habitat will be designated as "Training Restricted Zones" if it is located in maneuver training areas or "Burn Protection Zones" if it is located in live-fire areas. Fort Hood may propose, in consultation with USFWS, a lower mitigation ratio if the installation can provide documentation that habitats receiving increased protected status are of equal or better quality than habitat areas that were lost. 
Any habitat loss including loss considered incidental take will be reported on an annual basis to the installation Commander and to the USFWS as part of the installation's annual reporting requirement.

\section{Management}

Objective

Maintain currently available habitat consistent with population carrying capacity goal and essential mission requirements.

\section{Objective J ustification}

Fort Hood currently provides sufficient habitat to meet population carrying capacity goals under this ESMP and to exceed USFWS recovery objectives. Limited opportunities exist to further increase habitat availability. Maintenance of these habitats in excess of USFWS recovery goals will promote the long-term survival of the species, which is in the interest of the Army and Fort Hood to achieve greater training flexibility.

\section{Conservation Actions}

The installation will maintain currently available habitat by avoiding any habitat disturbing activities due to training or other project actions consistent with mission requirements. Normally, complying with the Fort Hood Endangered Species Training Guidelines and provisions of this ESMP will meet this objective.

Evaluate threat of oak wilt to warbler habitats on Fort Hood and determine priority threats from oak wilt. Based on this priority ranking, implement appropriate treatment and/or isolation methods to reduce oak-wilt threat to warbler habitats.

\section{Monitoring}

Objective

Document golden-cheeked warbler population trend. 


\section{Objective J ustification}

Population change is the baseline measure of conservation success and recovery for the population. This measure is necessary to differentiate between normal annual variability and true trends in populations over time.

\section{Conservation Actions}

Conduct point count censuses on a minimum of 318 points to obtain numbers of birds detected per location per observer, annually.

Determine numbers of singing males within designated intensive study areas, annually.

\section{Objective}

Assess population status by monitoring demographic parameters.

\section{Objective J ustification}

These measures are necessary to evaluate effects of management actions, to improve predictive capability of population viability models, and to determine cause and effect relationships between land use practices, including military training, and populations of golden-cheeked warblers.

\section{Conservation Actions}

Monitor selected populations occurring in areas not subject to training restrictions under the Fort Hood Endangered Species Training Guidelines to assess potential effects of unrestricted training on habitats and populations in these areas

Establish two intensive study areas in TA 13B (213 ha) and 22A/WFH (130 ha; Figure 9).

Conduct the following activities annually in each of the intensive study areas:

- Band all adults possible with a unique combination of leg bands.

- Locate and monitor active nests to the extent possible.

- Search for returning, banded birds.

- Band juveniles (HY). 
Monitor the following demographic and reproductive parameters annually in all intensive study areas:

- Banding status of all birds observed.

- Presence or absence of a female on each male territory.

- Territory size.

- Number of young with each adult.

- For all nests located; number of host and parasite eggs, nestlings, fledglings, and nest fate.

- Distance from banding location to resighting location in subsequent years.

As time permits, search areas throughout the installation where birds have been banded in the past for returning birds including returning $\mathrm{HY}$.

The only regular monitoring activity within the live-fire area will be to conduct annual point counts. The Fort Hood Natural Resources Branch will schedule access through the G3, Range Control.

\section{Research}

Objective

Refine and validate population viability models for golden-cheked warblers on Fort Hood.

\section{Objective J ustification}

Population viability models help managers establish measurable criteria for establishing population objectives and monitoring progress toward those objectives. Population goals under this ESMP were based on predictive capabilities of current PVA. Currently available PVA are limited to some extent by assumptions inherent in the models and imperfect knowledge of model parameters (see discussion Appendix D). Validation and refinement of these models will enhance their predictive capability and confidence in prescriptive management practices based on these analyses.

\section{Conservation Actions}

Update model parameter estimates as new data from research and monitoring efforts become available. 
Cross-validate current population viability analyses by performing simulations using alternative modeling platforms.

Incorporate results of improved and validated models in revisions of the Fort Hood ESMP as appropriate.

Objective

Evaluate relationship of habitat quality and golden-cheeked warbler abundance and productivity.

\section{Objective J ustification}

This research supports determination of installation carrying capacity for gol den-cheeked warbler populations on F ort Hood. This information is necessary to validate population goals and mitigation areas for the installation.

\section{Conservation Actions}

Analyze currently available vegetation data to investigate habitat selection of gol den-cheeked warblers.

Incorporate results of this research with monitoring results to refine estimates of carrying capacity for F ort Hood.

\section{Objective}

Evaluatefirerelated dispersal patterns of gol den-cheeked warblers.

\section{Objective J ustification}

The February 1996 wildfire on Fort Hood burned 2313 ha of golden-cheeked warbler habitat. In addition to habitat loss, such a fire potentially displaces returning adults, with unknown effects on population dynamics of remaining breeders on the installations. This research is necessary to evaluate effects, if any, of such a large fire event on golden-cheeked warblers.

\section{Conservation Actions}

Analyze results of field studies conducted in FY96-97 to evaluate productivity, population dynamics and dispersal of breeding adult golden-cheeked warblers from fire-disturbed habitats. 
Report study results to USFWS.

\section{Objective}

Evaluate effects of recreational off-road vehicle (motorized and nonmotorized) use on golden-cheeked warbler demography and productivity.

\section{Objective J ustification}

Human activities on Fort Hood other than training may affect golden-cheeked warbler demography and productivity. One of these recreational activities, offroad vehicle use, is common in warbler habitats throughout the species' range in Texas. This research will provide data on the relative effect of human recreational activities on golden-cheeked warblers.

\section{Conservation Actions}

Restrict all recreational off-road vehicle use to the devel oped track site within TA 34D, with the exception of the use of mountain bikes at the mountain bike park located at the Belton Lake Outdoor Recreation Area (BLORA).

Evaluate effects on golden-cheeked warbler demography and productivity in habitats adjacent to the mountain bike park at BLORA. 


\section{Conservation Actions: Black-capped Vireo}

\section{Population Goal}

Objective

Maintain sufficient habitat to support a minimum carrying capacity of 1000 singing males.

\section{Objective J ustification}

Current population viability analyses (Appendix D) indicate that habitat carrying capacity lower than that necessary to support 1000 singing males of blackcapped vireos greatly increases the probability of extinction. As shown in Figure 6, increasing carrying capacities above 1000 singing males does not significantly alter the probability of extinction. Carrying capacity represents the maximum potential of the habitat to support singing males. Carrying capacity does not necessarily reflect the number of singing males normally expected to occur. As shown in Figure 7, increases in carrying capacity above 1000 singing males also does not increase significantly the expected number of singing males present. A population carrying capacity goal in excess of 1000 singing males would not significantly lower extinction probability or significantly increase expected number of individuals. At this time, a population carrying capacity goal of 1000 singing males meets USFWS recovery objectives for this species. Also, establishment of a goal in excess of 1000 singing males on Fort Hood would likely require conversion of currently available golden-cheeked warbler habitat, which could jeopardize recovery objectives for the warbler on Fort Hood.

\section{Conservation Actions}

Current population viability analysis (PVA) and observed densities of adult males indicate a minimum of 4170 ha of black-capped vireo habitat is necessary to achieve a carrying capacity for 1000 singing males. Under current assumptions and parameter estimates of the PVA (Appendix D), F ort Hood has sufficient habitat to meet this objective. Current estimate of available habitat on Fort 
Hood is 2649 ha, with an additional 2670 ha of habitat becoming suitable for occupation during the 5-year term of this ESMP, for a total of 5319 ha of habitat available within 5 years. The Conservation Action to meet this objective will be to minimize loss of black-capped vireo habitat on Fort Hood due to fire, training, or other habitat altering activities in accordance with protection and management objectives established under this ESMP.

\section{Protection}

Objective

Implement training restrictions in designated "core" habitats in accordance with Fort Hood Endangered Species Training Guidelines (Appendix C).

\section{Objective J ustification}

Anecdotal observations suggest that some level of mechanical disturbance due to military training may help maintain habitat in seral stages suitable for blackcapped vireo occupation. However, military training in areas occupied by blackcapped vireos can destroy habitat and disturb individuals, potentially resulting in reduced abundance and productivity. These impacts increase the possibility of "take" as defined in the ESA. The Fort Hood Biological Opinion (USFWS 2000) states that implementation of the Fort Hood Training Guidelines in endangered species habitat is sufficient to avoid take of black-capped vireo habitats. Implementation of the Fort Hood Training Guidelines in the areas designated in this plan meets population goals for carrying capacity under this ESMP. "Core" habitat areas designated for protection under this objective were selected because of known population distributions, quality and contiguity of habitat, and minimal mission conflicts.

\section{Conservation Actions}

Implement Fort Hood Endangered Species Training Guidelines for 4184 ha of black-capped vireo habitat designated as "core" habitats (Table 2, Figure 8). Areas within live-fire areas will be designated as "Burn Protection Zones." Areas in maneuver training areas will be designated as "Training Restricted Zones." 
Objective

Reduce training restrictions in designated "non-core" habitats consistent with essential mission requirements.

\section{Objective J ustification}

The 4184 ha designated as "core" black-capped vireo habitat protected under the Fort Hood Endangered Species Training Guidelines exceeds the current estimate of habitat (4170 ha) necessary to achieve a population carrying capacity goal of 1000 singing males. Total vireo habitat on F ort Hood (5319 ha) exceeds the habitat area designated as "core" habitat. Protection of "non-core" habitat will be in accordance with incidental take limits and mitigation requirements as described under the foll owing objective for establishing incidental take limits. Designation of areas as "non-core" habitat is based on essential mission training requirements and does not imply any qualitative difference between "core" and "noncore" habitat with regard to suitability as black-capped vireo habitat. Designation of vireo habitat as "core" or "non-core" is related only to training activities allowed under these respective designations.

\section{Conservation Actions}

Training restrictions under the Fort Hood Endangered Species Training Guidelines will be rescinded on 1135 ha of black-capped vireo habitat areas identified in Figure 4.

The Fort Hood Natural Resources Branch will maintain records and maps of all areas occupied by endangered species regardless of protected status under the Fort Hood Endangered Species Training Guidelines.

"Non-core" habitat areas will remain subject to all other applicable Fort Hood range regulations, in particular regulations governing activities that could result in permanent alteration to endangered species habitat. An example would be the requirement to submit for approval Excavation Permit \#420-X10 prior to initiating any excavation activities on the installation. 
Objective

Implement a sustainableincidental take limit for the 5-year term of this ESMP.

\section{Objective J ustification}

The intent of this ESMP is to promote recovery of endangered species on Fort Hood lands while permitting the military maximum flexibility to perform mission essential tasks. Current estimates of available black-capped vireo habitat on Fort Hood exceed population and recovery goals under this ESMP. Implementation of incidental take limits provides flexibility for conducting mission activities that may result in habitat loss. However, this potential habitat loss is limited so as not to jeopardize baseline habitat requirements and to provide an adequate habitat mitigation bank in perpetuity without implementing further restrictive measures on the military mission.

Habitat "Ioss" as defined under this ESMP is any permanent or temporary alteration of currently suitable habitat to the extent that it is unsuitable for occupation by breeding adults. Mitigation requirements described below for habitat loss exceeding incidental take limits provide F ort Hood an incentive to carefully consider any permanent alteration or excessive loss of endangered species habitats.

\section{Conservation Actions}

Fort Hood will implement an incidental take limit of 230 ha of black-capped vireo habitat during the 5-year term of this ESMP. Incidental take provided under this ESMP will be limited to those military activities associated with transient training activities in habitats not subject to the Fort Hood Endangered Species Training Guidelines and loss due to uncontrolled burns in all habitat areas. Proposed projects and land use actions that will permanently alter endangered species habitats are subject to Section 7 requirements of the ESA. This incidental take will not apply to any proposed project or training action determined to permanently alter endangered species habitats. Such activities will require Fort Hood to initiate Section 7 consultation with the USFWS prior to implementation. Specific incidental take thresholds and required actions for habitat loss during the 5-year term of this ESMP are described below. 


\begin{tabular}{|l|l|}
\hline $\begin{array}{l}\text { Habitat loss } \\
\text { (hectares) }\end{array}$ & Action Required \\
\hline $0-230$ & $\begin{array}{l}\text { No action required for loss due to transient training activities in areas not subject to the } \\
\text { Fort Hood Endangered Species Training Guidelines (i.e., Non-Core Habitat) and loss } \\
\text { due to fire in all habitat areas. Report annually to USFWS as part of regular reporting } \\
\text { requirement. }\end{array}$ \\
& $\begin{array}{l}\text { Loss due to proposed construction activities or other permanent takings requires Sec- } \\
\text { tion } 7 \text { consultation. } \\
\text { Loss due to training activities in areas subject to the Fort Hood Endangered Species } \\
\text { Training Guidelines (i.e., "Core" Habitat) requires Section 7 consultation. }\end{array}$ \\
\hline$>230$ & $\begin{array}{l}\text { Incidental take under the Incidental Take Statement and Fort Hood's ESMP is ex- } \\
\text { ceeded. Requires Section } 7 \text { consultation with USFWS. Implement Endangered Spe- } \\
\text { cies Training Guidelines on habitat at a 4:1 ratio of protected habitat / habitat loss. }\end{array}$ \\
\hline
\end{tabular}

The incidental take limit for black-capped vireo habitat is based on three criteria:

1. Available habitat in excess of the 4170 ha necessary to meet ESMP carrying capacity objectives provides a mitigation bank for habitat loss at a 4:1 ratio.

2. Incidental take limit for the 5-year term of this ESMP is based on a renewable 5year regeneration cycle for vireo habitat.

3. As long as habitat loss remains within incidental take limits, no additional protective measures are required.

Under the first criterion, available habitat of 5319 ha (Table 2) on F ort Hood exceeds the estimated baseline requirement (4170 ha) necessary to meet population carrying capacity goals by 1149 ha. At a 4:1 mitigation ratio, the current 1149 ha of habitat in excess of the baseline requirement provides a mitigation bank for a potential habitat loss totaling no more than 230 ha.

Based on the second criterion that vireo habitat has an approximate regeneration cycle of 5 years, a loss rate of 230 ha per 5 -year period would maintain baseline habitat requirements with no net loss in habitat currently available for mitigation in excess of the baseline habitat requirement. At this loss rate, the total amount of habitat loss at any point in time would never exceed 230 ha due to regeneration of disturbed habitats on a 5-year cycle. Therefore, sufficient habitat would be maintained in excess of the baseline requirement to mitigate at a 4:1 ratio for this rate of habitat loss.

The third criterion is based on the adequacy of available habitat to provide a mitigation bank without implementing additional protective measures for habitat loss not exceeding 230 ha during the 5-year term of this ESMP. Habitat loss 
exceeding the incidental take limit of 230 ha will require Section 7 consultation and an increase in the area designated as "core" habitat at a 4:1 mitigation ratio. Mitigation habitat will be designated as "Training Restricted Zones" if it is located in maneuver training areas or "Burn Protection Zones" if it is located in live-fire areas. Fort Hood may propose, in consultation with USFWS, a lower mitigation ratio if the installation can provide documentation that habitats receiving increased protected status are of equal or better quality than habitat areas that were lost.

Any habitat loss including loss considered incidental take will be reported on an annual basis to the installation Commander and to the USFWS as part of the installation's annual reporting requirement.

Due to the ephemeral nature of black-capped vireo habitat, some level of disturbance must be implemented in vireo habitats to maintain seral stage preferred by vireos (see Management objectives and conservation actions below). Habitat loss due to wildfire or training disturbance will not be considered incidental take if it meets and contributes to habitat management goals described below. Fort Hood will maintain records of all habitat maintenance activities and report these activities to the USFWS as part of the installation's annual reporting requirement.

\section{Management}

Objective

Maintain sufficient habitat to meet population goal in seral stage suitable for occupation by black-capped vireos.

\section{Objective J ustification}

Typically, vireos on Fort Hood are observed in early successional habitat resulting from burns or mechanical clearing of vegetation in areas with suitable soils and geologic substrate (see Chapter 3, Species Accounts and Current Status on Fort Hood). Currently, 5319 ha have been identified on Fort Hood as currently suitable or anticipated vireo habitat. This designated habitat comprises areas that have been identified as suitable for vireo habitat management activities. This habitat area does not include occupied vireo territories in areas currently designated as golden-cheeked warbler habitat. Due to the ephemeral nature of habitat in these areas targeted for habitat management, restoration must be implemented to replace areas where vegetation has succeeded beyond the stage 
preferred by vireos. This objective maintains at least the current level of managed vireo habitat on Fort Hood.

\section{Conservation Actions}

Due to the extensive amount of recently burned habitat, much of the existing and potential vireo habitat is in early seral stage ( $<3$ years) on Fort Hood and will not require extensive habitat maintenance activities during the 5-year term of this ESMP. However, a future requirement to maintain the current 5319 ha of habitat in an early seral stage (typically 1-20 years post-disturbance) will require installation land managers to implement habitat restoration to maintain habitat in the desired seral stage. Fort Hood will develop and submit to USFWS for re view and approval a black-capped vireo habitat restoration plan for incorporation in subsequent ESMP revisions. This habitat restoration plan will be guided by observed vegetation condition, vireo occupancy, and expert opinion. Normally, vireo habitat management will target habitat areas exceeding the preferred seral stage (typically $>20$ years post-disturbance). However, physiographic and other conditions can influence vegetation growth rates and composition, which may be reflected in vireo occupancy. As an example, where vireo occupancy remains high in areas $>20$ years post-disturbance, these areas will likely not be manipulated until occupancy rates exhibit decline. Conversely, some areas with low or sharply declining populations $<20$ years post-disturbance may be eligible for active habitat manipulation to restore preferred vegetation composition and structure.

\section{Objective}

Maintain parasitism of vireo nests by brown-headed cowbirds below an average of 10 percent annually in non-livefire training areas during the 5-year term of this ESMP.

\section{Objective J ustification}

Cowbird parasitism reduces reproductive success of black-capped vireos on Fort Hood (Tazik et al. 1992; Hayden et al. 2000). Analyses by Tazik (1991) of the effect of cowbird parasitism on vireo productivity indicate that incidence of cowbird parasitism must be below 25 percent to maintain stable or increasing vireo populations. A target goal of average annual parasitism below 10 percent was determined because of effectiveness of historical control efforts and to be consistent with thresholds established by the USFWS under other agreements. Since 1992, cowbird control efforts have maintained parasitism levels in non-live-fire areas below 10 percent on F ort Hood. Also, USFWS has established a 10 percent 
parasitism threshold in provisions of a Memorandum of Understanding with Central Texas Cattleman's Association regarding grazing leases on Fort Hood. Maintaining parasitism levels below an average of 10 percent annually will enhance vireo reproductive success on F ort Hood and support achievement of population objectives. Reducing cowbird parasitism is the only management technique currently available to directly affect reproductive success.

\section{Conservation Actions}

Remove a sufficient number of female cowbirds during the peak vireo breeding months, March-J une, to maintain parasitism levels below an annual average of 10 percent for all non-live-fire training areas for the 5-year term of this ESMP. Historically, removal in excess of 2000 female cowbirds annually on Fort Hood is correlated with parasitism levels below these levels (Hayden et al. 2000). Trap effort will be conducted at levels sufficient to maintain parasitism levels below the 10 percent annual target.

Shooting will be conducted within selected occupied vireo habitats where high levels of cowbird parasitism have been documented despite trapping effort.

Cowbird trapping during the months J uly-February will be conducted to reduce resident adult cowbird populations, reduce juvenile female abundance, reduce vandalism damage, and provide year-round presence and awareness among troops training in the field.

With the completion of cattle/cowbird studies (Koloszar and Horne 2000) in the northeast training ranges, cowbird control activities including trapping and shooting will be enhanced in the northeast training ranges (TAs 1-19).

Consultation with USFWS will be initiated if the 5-year average of 10 percent annual parasitism is exceeded. The intent of this objective is to maintain an average annual parasitism rate below 10 percent over the 5-year term of the ESMP, i.e., a rate greater than 10 percent in any one year would not necessarily trigger consultation unless the annual rate precluded achieving a 5-year average of less than 10 percent. This, in effect, calculates a rolling average determined annually during the 5-year term of the ESMP by adding the annual parasitism rate for all years up to the current implementation year and dividing by five. If the result is an average parasitism rate greater than 10 percent, the installation will initiate consultation with the USFWS. The formula for this calculation is:

$$
\mathrm{P}_{\mathrm{avg}}=(\mathrm{P} 1+\ldots \mathrm{Pn}) / 5
$$


Where $\mathrm{P}_{\text {avg }}$ is the average annual parasitism for the 5-year term of this ESMP. $\mathrm{P} 1$ is Parasitism in the first year of implementation of the ESMP and Pn is parasitism in the current year of implementation of the ESMP. $(P 1+\ldots P n)$ is the sum of annual parasitism rates for all years through the current year of implementation. Annual parasitism rates and the calculation of the 5-year average parasitism rate will be reported annually to the USFWS as part of the annual reporting requirement.

Radio-telemetry studies were completed in FY98 (Koloszar and Horne 2000) to evaluate the relationship between cattle grazing and brown-headed cowbirds on Fort Hood. Preliminary results of this research indicate the occurrence of cowbirds and parasitism levels are linked to the presence of cattle. The Department of the Army is currently evaluating the relative efficiency and effectiveness of cowbird control activities versus modification of current cattle leasing agreements on Fort Hood in reducing cowbird parasitism on Fort Hood. Based on this evaluation, cattle grazing may be modified on Fort Hood with the objective of reducing impacts on endangered avian species populations. Vireo populations will be monitored to determine whether alterations in cattle grazing on Fort Hood are effective in controlling incidence of cowbird parasitism.

\section{Monitoring}

Objective

Document black-capped vireo population trend.

\section{Objective J ustification}

Population change is the base-line measure of conservation success and recovery for the population. This measure is necessary to differentiate between normal annual variability and true trends in populations over time.

\section{Conservation Actions}

Determine numbers of singing males within each of three intensive study areas, annually.

As time permits, visit all known and suspected sites of vireo occupation to document distribution of black-capped vireos on F ort Hood. 
Objective

Assess population status by monitoring demographic parameters.

\section{Objective J ustification}

These measures are necessary to evaluate effects of management actions, to improve predictive capability of population viability models, and to determi ne cause and effect relationships between land use practices, including training, and populations of black-capped vireos.

\section{Conservation Actions}

Monitor populations annually in three intensive study areas in TAs 44B, East Ranges (TAs 2, 5A, and 5B) and West Fort Hood (Figure 10).

Conduct the following actions annually in each of the three intensive study areas and the live-fire area:

- Monitor all territories in each intensive study area throughout the vireo breeding season.

- Monitor at least 40 territories in the live-fire zone with representation from each of five "E nvironmental Watch Areas" (Figure 11). Environmental Watch Areas within the live-fire zone are designated by agreement between the installation Fish and Wildlife Branch and G3. Normally, this monitoring re quirement will require access to each Environmental Watch Area approximately once every 2 weeks during the breeding season. This requirement will minimize conflict with ongoing training by maximum use of weekend training holidays, range maintenance periods, and other training downtime through coordination with G3.

- Locate and monitor all located nests on monitored territories.

- Band all adults, juveniles, and nestlings to the extent possible.

Monitor the following demographic and reproductive parameters for all monitored territories:

- Banding status of all birds observed.

- Presence or absence of a female on each male territory.

- Territory size.

- Number of young with each adult.

- For all nests located; number of host and parasite eggs, nestlings, fledglings, and nest fate.

- Distance from banding location to resighting location in subsequent years. 
Monitor successional development of habitat and vireo colonization in areas burned during the February 1996 fire.

\section{Research}

Objective

Refine and validate population viability models for black-capped vireos on Fort Hood.

\section{Objective J ustification}

Population viability models help managers establish measurable criteria for establishing population objectives and monitoring progress toward those objectives. Population goals under this ESMP were based on predictive capabilities of current population viability analyses. Currently available PVA are limited to some extent by assumptions inherent in the models and imperfect knowledge of model parameters (see discussion Appendix D). Validation and refinement of these models will enhance their predictive capability and confidence in prescriptive management practices based on these analyses.

\section{Conservation Actions}

Update model parameter estimates as new data from research and monitoring efforts become available.

Cross-validate current population viability analyses by performing simulations using alternative modeling platforms.

Incorporate results of improved and validated models in revisions of the Fort Hood ESMP as appropriate.

\section{Objective}

Determine predator types and effects of depredation on black-capped vireo nests.

\section{Objective J ustification}

Population viability analyses and monitoring results indicate that demographic and productivity factors currently are more limiting than habitat availability for vireo populations on Fort Hood. Depredation is a significant factor in nest loss 
and lower productivity. This research will help determine species that depredate vireos and provide managers information necessary to develop mitigation strategies for nest depredation.

\section{Conservation Actions}

Conduct remote camera studies at nest sites to identify predators at vireo nest sites.

Develop management strategies to mitigate effects of nest depredation and incorporate these strategies in future ESMP revisions.

\section{Objective}

Evaluate effects of recreational off-road vehicle (motorized and nonmotorized) use on black-capped vireo site fidelity and habitat use.

\section{Objective J ustification}

Human activities on Fort Hood other than training may affect black-capped vireo site fidelity and habitat use. One of these recreational activities, off-road vehicle use, is common in vireo habitats throughout the species' range in Texas. This research will provide data on the relative effect of human recreational activities on black-capped vireos.

\section{Conservation Actions}

Restrict all off-road vehicle use to the developed track site within TA 34D, with the exception of the use of mountain bikes at the mountain bike park located in the Belton Lake Outdoor Recreation Area (BLORA)

Evaluate effects on black-capped vireo site fidelity and habitat use by implementing banding studies in habitats adjacent to the track site in TA 34D. 


\section{Conservation Actions: Croton alabamensis}

\section{Protection}

Objective

Protect known locations from human-related disturbance.

\section{Objective J ustification}

Protection of known locations of croton populations from human-related disturbance is a proactive approach to mitigate impacts and possibly prevent listing of species as threatened or endangered. Known populations are in locations where virtually no military training is conducted and where training is restricted under the F ort Hood Endangered Species Training Guidelines.

\section{Conservation Actions}

No additional action is required at this time. All known populations of croton on Fort Hood occur within areas that are protected under the Fort Hood Endangered Species Guidelines. Protective measures of these guidelines are adequate to protect known croton populations from effects of military training. No other land use activities that may disturb croton populations are known to occur in these areas.

\section{Monitoring}

Objective

Monitor status and distribution of populations. 


\section{Objective J ustification}

Monitoring croton population trends will provide managers with information necessary to decide whether additional protection or management actions are required to maintain viable croton populations.

\section{Conservation Actions}

Visit known locations annually to visually assess condition of known populations. 


\section{Conservation Actions: Cave-adapted Fauna}

\section{Protection}

Objective

Protect sensitive cave and karst features from human-related risk factors identified in the Endangered Karst Invertebrates Recovery PIan (USFWS 1994).

\section{Objective J ustification}

Human activities and changes to surrounding habitats are the greatest threat to cave-adapted fauna. Protection of cave features from these impacts is a proactive approach to mitigate potential impacts and possibly prevent listing of species potentially eligible for threatened or endangered status.

\section{Conservation Actions}

Gates have been placed at entrances to caves that have been identified as particularly sensitive and susceptible to human disturbance. The following actions should be followed to construct and maintain gates for sensitive cave and karst features:

- I Inspect all current cave gates annually and perform any necessary maintenance.

- I dentify any additional cave or karst features susceptible to human disturbance and determine if gates would alleviate potential problems. Fund and implement construction of additional gates if appropriate.

In the vicinity of cave and karst features where military training increases risk of vegetation destruction and sedimentation, buffer zones should be implemented by placing signs or other barriers at sufficient distance from cave entrances to minimize disturbance. 


\section{Monitoring}

Objective

Monitor changes in representative samples of endemic cave fauna and species listed or proposed for listing in the future.

\section{Objective J ustification}

Monitoring cave-adapted faunal communities will assist managers in identifying any potential impacts on cave-adapted fauna. This monitoring will determine effectiveness of protective measures and may prevent the need to list species as threatened or endangered.

\section{Conservation Actions}

Select a representative sample of cave and karst features with endemic invertebrate populations for long-term monitoring.

Conduct representative baseline sampling to provide index of species composition and abundance.

Develop long-term sampling protocol to evaluate population trends of invertebrate populations.

\section{Objective}

Locate, map, and conduct biological collections in sensitive cave and karst features on Fort Hood.

\section{Objective J ustification}

This objective will meet the requirement of the ESA to determine presence of listed species and will identify potential for conflicts with mission and land use activities on F ort Hood.

\section{Conservation Actions}

Conduct biological collections in known cave and karst features if such collections have not previously been performed or are incomplete. 
Locate and survey cave and karst features in areas subject to military training or other land use activities which would potentially result in disturbance of these features.

\section{Research}

Objective

Complete taxonomic evaluation and description of undescribed material collected from F ort Hood caves.

\section{Objective J ustification}

This work is necessary to identify a new species potentially eligible for listing or species that are currently listed as endangered.

\section{Conservation Actions}

Submit taxonomic findings to USFWS for status review.

\section{Objective}

Complete taxonomic evaluation of the undescribed salamander first collected in 1992.

\section{Objective J ustification}

This work is necessary to identify a new species potentially eligible for listing or enhance protection to prevent future listing.

\section{Conservation Actions}

Submit taxonomic findings to USFWS for status review.

\section{Objective}

Determineimpact of fireants on caveadapted fauna. 


\section{Objective J ustification}

This is the only known non-human-related factor that may threaten sensitive cave-adapted fauna. The extent to which fire ants impact cave fauna is unknown. This research will help identify necessary management actions if fire ants do threaten cave fauna.

\section{Conservation Actions}

Establish treated and control plots to evaluate effects of fire ants on endemic cave invertebrate populations on Fort Hood.

Based on study findings, develop appropriate management objectives and actions and incorporate in future revisions of the Fort Hood ESMP. 


\section{Conservation Actions: Other Species}

\section{Protection}

Objective

Bald Eagle: Minimize disturbance from low-level helicopter flights and other aviation assets.

\section{Objective J ustification}

The ESA requires protection from harassment for all listed species. Low-level aircraft flights can disturb wintering populations of this species occurring near Belton Lake.

\section{Conservation Actions}

When bald eagles are first observed in autumn, notify the Fort Hood air-space coordinator, and implement the no-fly zone. This zone is situated on and near Belton Lake in parts of TAs 3B, 6A, 6B, and 7B. Flight restrictions will be lifted when no bald eagles have been observed for a period of 2 weeks.

\section{Objective}

Whooping Crane: If whooping cranes are observed, protect from potential disturbance by military training and other land useactivities.

\section{Objective J ustification}

The ESA requires protection from harassment for all listed species. Whooping crane presence on the installation is likely to be highly transitory during migration. For this reason no specific protection plan appears warranted at this time. However, activity of transient individuals should be monitored to prevent potential disturbance from human activity. 


\section{Conservation Actions}

Monitor activity of whooping cranes while present on the installation.

Notify G3, Range Control, and other appropriate training and operations organizational elements of any potential training disturbance in proximity to observed individuals.

Suspend training activities in proximity to whooping cranes until they have departed installation lands.

\section{Objective}

Peregrine Falcon: If peregrine falcons are observed, monitor presence for potential disturbance from human activity.

\section{Objective J ustification}

The Peregrine Falcon was delisted in 1999. The ESA requires monitoring for 5 years after delisting. Peregrine falcon presence on the installation is likely to be highly transitory during migration and not associated with any particular physical feature of the installation as in the case for whooping cranes and bald eagles (i.e., Belton reservoir). For these reasons no specific protection plan appears warranted at this time. However, activity of transient individuals should be monitored to prevent potential disturbance from human activity.

\section{Conservation Actions}

Monitor activity of peregrine falcons while present on the installation.

Notify G3, Range Control, and other appropriate training and operations organizational elements of any potential training disturbance in proximity to observed individuals.

\section{Monitoring}

\section{Objective}

Conduct surveys to determine presence and status of other listed, rare, and sensitivespecies. 


\section{Objective J ustification}

The ESA requires Federal agencies to document the presence of and assess effects of land use activities on any species occurring on Fort Hood lands that may be eligible or proposed for listing in the future. Documentation of these species' presence and status will meet ESA requirements and is a proactive approach to avoiding project conflicts in the future. The preferred outcome is to identify and implement necessary management actions to avoid listing of species under the ESA.

\section{Conservation Actions}

Installation biologists will review species listed in Table 1 annually and will revise and amend as appropriate.

Based on the installation review above, surveys will be initiated as necessary to document presence and status of listed, rare, or sensitive species on the installation.

Results of these surveys will be kept on record by the Fort Hood Natural Resources Branch and submitted to the USFWS. 


\section{Resource Requirements}

Estimate of required resources for Fort Hood endangered species research and management for FY01-05. Estimates are organized by fiscal year and include personnel costs where applicable.

\begin{tabular}{|c|c|c|c|}
\hline FY & Major Activity or Cost Category & $\begin{array}{c}\text { Cost } \\
\text { (thousands of \$) }\end{array}$ & $\begin{array}{c}\text { Total } \\
\text { (thousands of \$) }\end{array}$ \\
\hline \multirow[t]{11}{*}{01} & Program management & 66 & \\
\hline & Black-capped vireo research and monitoring & 429 & \\
\hline & Golden-cheeked warbler research and monitoring & 326 & \\
\hline & Brown-headed cowbird research and control & 262 & \\
\hline & Forest mgt., firebreaks, and prescribed burning & 425 & \\
\hline & Predation effects and control studies & 725 & \\
\hline & Fire control equipment and support & 475 & \\
\hline & Fire damage abatement research and monitoring & 434 & \\
\hline & Caves and cave fauna monitoring and research & 185 & \\
\hline & Species surveys and biological assessments & 100 & \\
\hline & \multicolumn{2}{|l|}{ FY01 Total } & 3427 \\
\hline \multirow[t]{14}{*}{02} & Program management & 69 & \\
\hline & Black-capped vireo research and monitoring & 454 & \\
\hline & Golden-cheeked warbler research and monitoring & 390 & \\
\hline & Brown-headed cowbird research and control & 158 & \\
\hline & Forest mgt., firebreaks, and prescribed burning & 1210 & \\
\hline & Predation effects and control studies & 750 & \\
\hline & Fire control equipment and support & 225 & \\
\hline & Fire damage abatement research and monitoring & 465 & \\
\hline & Caves and cave fauna monitoring and research & 112 & \\
\hline & Species surveys and biological assessments & 100 & \\
\hline & Habitat Delineation- Signing and Mapping & 205 & \\
\hline & Off-Site Mitigation & 2000 & \\
\hline & Natural Resource Law Enforcement & 305 & \\
\hline & \multicolumn{2}{|l|}{ FY02 Total } & 6443 \\
\hline \multirow[t]{14}{*}{03} & Program management & 72 & \\
\hline & Black-capped vireo research and monitoring & 459 & \\
\hline & Golden-cheeked warbler research and monitoring & 400 & \\
\hline & Brown-headed cowbird research and control & 158 & \\
\hline & Forest mgt., firebreaks, and prescribed burning & 760 & \\
\hline & Predation effects and control studies & 780 & \\
\hline & Fire control equipment and support & 225 & \\
\hline & Fire damage abatement research and monitoring & 469 & \\
\hline & Caves and cave fauna monitoring and research & 112 & \\
\hline & Species surveys and biological assessments & 100 & \\
\hline & Habitat Delineation - Signing and Mapping & 210 & \\
\hline & Off - Site Mitigation & 2000 & \\
\hline & Natural Resource Law Enforcement & 205 & \\
\hline & \multicolumn{2}{|l|}{ FY03 Total } & 5950 \\
\hline \multirow[t]{5}{*}{04} & Program management & 76 & \\
\hline & Black-capped vireo research and monitoring & 463 & \\
\hline & Golden-cheeked warbler research and monitoring & 415 & \\
\hline & Brown-headed cowbird research and control & 166 & \\
\hline & Forest mgt., firebreaks, and prescribed burning & 635 & \\
\hline
\end{tabular}




\begin{tabular}{|c|c|c|c|}
\hline FY & Major Activity or Cost Category & $\begin{array}{c}\text { Cost } \\
\text { (thousands of \$) }\end{array}$ & \multirow[t]{9}{*}{$\begin{array}{c}\text { Total } \\
\text { (thousands of \$) }\end{array}$} \\
\hline & Predation effects and control studies & 790 & \\
\hline & Fire control equipment and support & 230 & \\
\hline & Fire damage abatement research and monitoring & 469 & \\
\hline & Caves and cave fauna monitoring and research & 102 & \\
\hline & Species surveys and biological assessments & 100 & \\
\hline & Habitat Delineation - Signing and Mapping & 210 & \\
\hline & Off - Site Mitigation & 2000 & \\
\hline & Natural Resource Law Enforcement & 222 & \\
\hline & \multicolumn{2}{|l|}{ FY04 Total } & 5878 \\
\hline \multirow[t]{15}{*}{05} & Program management & 80 & \\
\hline & Black-capped vireo research and monitoring & 467 & \\
\hline & Golden-cheeked warbler research and monitoring & 425 & \\
\hline & Brown-headed cowbird research and control & 166 & \\
\hline & Forest mgt., firebreaks, and prescribed burning & 640 & \\
\hline & Predation effects and control studies & 810 & \\
\hline & Fire control equipment and support & 150 & \\
\hline & Fire damage abatement research and monitoring & 472 & \\
\hline & Caves and cave fauna monitoring and research & 102 & \\
\hline & Species surveys and biological assessments & 100 & \\
\hline & Habitat Delineation - Signing and Mapping & 210 & \\
\hline & Off - Site Mitigation & 2000 & \\
\hline & Natural Resource Law Enforcement & 238 & \\
\hline & \multicolumn{2}{|l|}{ FY05 Total } & 5860 \\
\hline & \multicolumn{2}{|l|}{ Grand Total } & 27558 \\
\hline
\end{tabular}




\section{Checklist}

Activity, reporting, and compliance checklist for the Fort Hood Endangered Species Management Plan.

\begin{tabular}{|c|c|c|c|}
\hline \multirow[t]{2}{*}{ Schedule } & \multirow[t]{2}{*}{ Activities } & \multicolumn{2}{|c|}{ Implemented } \\
\hline & & Date & Signature \\
\hline \multirow[t]{8}{*}{ FY01 } & GCWA field research and monitoring & & \\
\hline & Cowbird control program & & \\
\hline & Report results of cowbird telemetry study to USFWS & & \\
\hline & BCVI field research and monitoring & & \\
\hline & BCVI nest predation study & & \\
\hline & Caves research and monitoring & & \\
\hline & Annual status report submitted to USFWS & & \\
\hline & Review of ESMP & & \\
\hline \multirow[t]{7}{*}{ FY02 } & GCWA field work & & \\
\hline & Cowbird control program & & \\
\hline & BCVI field work & & \\
\hline & BCVI nest predation study & & \\
\hline & Caves research and monitoring & & \\
\hline & Annual status report submitted to USFWS & & \\
\hline & Review of ESMP & & \\
\hline \multirow[t]{6}{*}{ FY03 } & GCWA field work & & \\
\hline & Cowbird control program & & \\
\hline & BCVI field work & & \\
\hline & Caves research and monitoring & & \\
\hline & Annual status report submitted to USFWS & & \\
\hline & Review of ESMP & & \\
\hline \multirow[t]{6}{*}{ FY04 } & GCWA field work & & \\
\hline & Cowbird control program & & \\
\hline & BCVI field work & & \\
\hline & Cave research and monitoring & & \\
\hline & Annual status report submitted to USFWS & & \\
\hline & Review of ESMP & & \\
\hline \multirow[t]{7}{*}{ FY05 } & GCWA field work & & \\
\hline & Cowbird control program & & \\
\hline & BCVI field work & & \\
\hline & Cave research and monitoring & & \\
\hline & Annual status report submitted to USFWS & & \\
\hline & Review of ESMP & & \\
\hline & Complete major revision of ESMP & & \\
\hline
\end{tabular}




\section{Tables}

Table 1. Federal endangered, threatened, and candidate species that occur or may occur on Fort Hood.

Several endemic cave invertebrates and a salamander species found on Fort Hood may eventually become candidate or listed species (see Table 3).

\begin{tabular}{|c|c|c|c|}
\hline Common Name & Scientific Name & Listing Status $^{\mathrm{a}}$ & Status $^{\mathrm{b}}$ \\
\hline \multicolumn{4}{|c|}{ FEDERALLY LISTED SPECIES } \\
\hline Crane, whooping & Grus americana & $\mathrm{E}$ & $\mathrm{B}$ \\
\hline Eagle, bald & Haliaeetus leucocephalus & $T$ & A \\
\hline Falcon, American peregrine & Falco peregrinus anatum & $\mathrm{E}^{* *}$ & $\mathrm{~B}$ \\
\hline Plover, piping & Charadrius melodus & $T$ & $\mathrm{C}$ \\
\hline Tern, least & Sterna antillarum & $E$ & $\mathrm{C}$ \\
\hline Vireo, black-capped & Vireo atricapillus & $E$ & $\mathrm{~A}$ \\
\hline Warbler, golden-cheeked & Dendroica chrysoparia & $E$ & $A$ \\
\hline \multicolumn{4}{|l|}{ CANDIDATE SPECIES } \\
\hline Swift fox (U.S. population) & Vulpes velox & C & $\mathrm{C}$ \\
\hline Mountain plover & Charadrius montanus & $\mathrm{C}$ & $\mathrm{C}$ \\
\hline \multicolumn{4}{|l|}{ SPECIES OF CONCERN } \\
\hline Texabama croton & Croton alabamensis & $\mathrm{N} / \mathrm{A}$ & A \\
\hline Salamander (new species) & Under taxonomic review & $\mathrm{N} / \mathrm{A}$ & $A$ \\
\hline Cave invertebrates & See Table 3 & $\mathrm{~N} / \mathrm{A}$ & A \\
\hline
\end{tabular}

a. Federal listing status; $\mathrm{E}=$ endangered, $\mathrm{T}=$ threatened, $\mathrm{C}=$ candidate.

b. Status refers to population status on Fort Hood according to these definitions:

A = Population established on Fort Hood. Recent information documents an established breeding population (even if small) or regular occurrence, on the installation. This includes those species for which research and management is ongoing and several endemic cave invertebrates.

$\mathrm{B}=$ Recently recorded on Fort Hood, but there is no evidence of an established population. This includes species considered to be transient, accidental, or migratory (e.g., some migrating birds may use the installation as a stopover site during migration to and from their wintering grounds). For some species in this category, further inventory may reveal breeding populations.

$\mathrm{C}=$ Not known to occur on or near Fort Hood, but there is some possibility of occurrence.

**Species delisted 08/25/99. Monitoring is required for 5 years after delisting. 
Table 2. Estimated habitat and incidental take limits for golden-cheeked warblers and blackcapped vireos during the 5-year term of this ESMP.

Estimated available habitat was determined from visual interpretation of aerial photography, known bird locations, and ground surveys. Baseline habitat requirement estimated from PVA analysis (Appendix D). "Core" habitat subject to Fort Hood Endangered Species Training Guidelines is inclusive of habitats designated as "Burn Protection Zones" and "Training Restricted Zones" on installation training area maps.

\begin{tabular}{||l|c||}
\hline \multicolumn{1}{||c|}{ Golden-cheeked Warbler } & Hectares \\
\hline \hline \multicolumn{1}{|c||}{ Black-capped Vireo } & 21,496 \\
\hline "Cotal available habitat & 14,879 \\
\hline Baseline habitat requirement & 8,520 \\
\hline Total allowable incidental take; FY01-05 & 519 \\
\hline \hline \multicolumn{1}{|c||}{} & \\
\hline \hline & Hectares \\
\hline Total available habitat & 5,319 \\
\hline "Core" habitat subject to Fort Hood Endangered Species Training Guidelines & 4,184 \\
\hline Baseline habitat requirement & 4,170 \\
\hline \multicolumn{2}{|c||}{} \\
\hline Total allowable incidental take; FY01-05 & 230 \\
\hline
\end{tabular}


Table 3. Cave associated species known from Fort Hood.

Other than the bifurcated cave amphipod, none of these species is currently listed or is a candidate for listing as threatened or endangered by the USFWS. Only species likely to be listed in the future are shown. Surveys and related research are ongoing.

Source: Mike Warton \& Associates and J ames R. Reddell.

\begin{tabular}{|c|c|c|c|c|c|c|}
\hline Species & Class & Order & Common Name & Cave Affinity & Range & Listing Status \\
\hline Stygobromus bifurcatus & Malacostraca & Amphipoda & $\begin{array}{l}\text { Bifurcated cave } \\
\text { amphipod }\end{array}$ & troglobite & Central Texas & Candidate, Federal, 2B \\
\hline Stygobromus russelli & Malacostraca & Amphipoda & amphipod & troglobite & Central Texas & Not listed \\
\hline Cicurina (Cicurella) coryelli & Arachnida & Araneae & spider & troglobite & Ft. Hood endemic & Not listed \\
\hline Cicurina (sp. nov.?) & Arachnida & Araneae & spider & troglophile & Ft. Hood endemic & Needs taxonomic work \\
\hline Texella (sp. nov.) & Arachnida & Phalangida & harvestman & troglobite & Ft. Hood endemic & Not listed \\
\hline Speodesmus (sp. nov.) & Diplopoda & & millipede & troglobite & Ft. Hood endemic & Not listed \\
\hline Siphonophora (sp. nov.?) & Diplopoda & & millipede & troglobite & Edwards Plateau & Needs taxonomic work \\
\hline Rhadine (sp. nov.) & Insecta & Coleoptera & ground beetle & troglobite & Ft. Hood endemic & Not listed \\
\hline Batrisodes (sp. nov.) & Insecta & Coleoptera & mold beetle & troglobite & Ft. Hood endemic & Not listed \\
\hline Batrisodes (sp. nov.) & Insecta & Coleoptera & mold beetle & troglobite & Ft. Hood endemic & Not listed \\
\hline Trimioarcus (sp. nov.) & Insecta & Coleoptera & Beetle & troglophile & Ft. Hood endemic & Not listed \\
\hline Ceuthophilus (sp. nov.) & Insecta & Orthoptera & cave cricket & trogloxene & Ft. Hood endemic & Not listed \\
\hline Plethodon sp.? & Amphibia & Caudata & salamander & trogloxene & Ft. Hood endemic & Needs taxonomic work \\
\hline
\end{tabular}


Table 4. Status of biological collections in surveyed (interior dimensions mapped) caves of Fort Hood.

\begin{tabular}{|c|c|c|c|}
\hline "Mapped Caves of Fort Hood & County & Report Cited In & Biology Studied \\
\hline Ammo-Can Sink & Coryell & 18 January $1993^{a}$ & No \\
\hline Big Ash Tree Sink & Bell & $\begin{array}{l}5 \text { July } 1992 \\
15 \text { February } 1993^{\text {a }} \\
12 \text { March } 1993\end{array}$ & 14 March 1992 \\
\hline Big Red Cave & Coryell & $\begin{array}{l}15 \text { May } 1991 \\
5 \text { July } 1992 \\
15 \text { February } 1993 \\
12 \text { March } 1993^{a}\end{array}$ & No \\
\hline Brokeback Cave (map from 1964) & Coryell & $\begin{array}{l}15 \text { May } 1991 \\
5 \text { July } 1992 \\
15 \text { February } 1993\end{array}$ & $\begin{array}{l}17 \text { August } 1964 \\
5 \text { September } 1991\end{array}$ \\
\hline Cedar Sink & Bell & 12 March $1993^{a}$ & No \\
\hline Copperhead Cave & Coryell & $\begin{array}{l}15 \text { May } 1991 \\
5 \text { July } 1992 \\
15 \text { February. } 1993 \\
10 \text { November } 1992 \\
18 \text { January } 1993^{a}\end{array}$ & $\begin{array}{l}\text { No } \\
1990 \text { Noted Copper- } \\
\text { head and Ringtail Cat }\end{array}$ \\
\hline $\begin{array}{l}\text { Doubletree Cave } \\
\text { (Rocket River Cave System as of } \\
10 \text { Nov 1992) }\end{array}$ & Coryell & $\begin{array}{l}15 \text { May } 1991 \\
5 \text { July } 1992 \\
15 \text { February } 1993^{\text {b }} \\
10 \text { November } 1992 \\
18 \text { January } 1993\end{array}$ & 27 January 1990 \\
\hline Egypt Cave & Coryell & $\begin{array}{l}15 \text { May } 1991 \\
5 \text { July } 1992 \\
15 \text { February } 1993 \\
18 \text { January } 1993^{b}\end{array}$ & $\begin{array}{l}13 \text { and } 21 \text { January } \\
1992\end{array}$ \\
\hline Feller's Cave & Bell & $\begin{array}{l}5 \text { July } 1992 \\
15 \text { February } 1993 \\
18 \text { January } 1993 \\
12 \text { March } 1993^{a}\end{array}$ & 4 December 1992 \\
\hline Goathead Cave & Coryell & $\begin{array}{l}15 \text { May } 1991 \\
5 \text { July } 1992 \\
15 \text { February } 1993 \\
12 \text { March } 1993^{b}\end{array}$ & $\begin{array}{l}5 \text { September } 1991 \\
5 \text { March } 1993\end{array}$ \\
\hline Hanging Stump Cave & Bell & $\begin{array}{l}5 \text { July } 1992 \\
15 \text { February } 1993^{a} \\
12 \text { March } 1993 \\
19 \text { July } 1993\end{array}$ & $\begin{array}{l}14 \text { March } 1992 \\
9 \text { March } 1993\end{array}$ \\
\hline Hannah Cave & Coryell & $\begin{array}{l}5 \text { July } 1992 \\
15 \text { February } 1993^{a} \\
10 \text { November } 1992\end{array}$ & 4 November 1992 \\
\hline Hollow Floor Cave & Bell & $\begin{array}{l}5 \text { July } 1992 \\
15 \text { February } 1993^{a} \\
12 \text { March } 1993\end{array}$ & 14 March 1992 \\
\hline Jagged Walls Cave & Bell & $\begin{array}{l}5 \text { July } 1992 \\
15 \text { February } 1993^{a} \\
18 \text { January } 1993 \\
12 \text { March } 1993 \\
19 \text { July } 1993\end{array}$ & $\begin{array}{l}14 \text { March } 1992 \\
4 \text { December } 1992\end{array}$ \\
\hline Mix-Master Cave & Coryell & 12 March $1993^{a}$ & 9 March 1993 \\
\hline $\begin{array}{l}\text { Nolan Creek Cave (map from } \\
1964 \text { ) }\end{array}$ & Bell & $\begin{array}{l}15 \text { May } 1991 \\
5 \text { July } 1992 \\
15 \text { February } 1993\end{array}$ & $\begin{array}{l}9 \text { March } 1963 \\
27 \text { January } 1990\end{array}$ \\
\hline
\end{tabular}




\begin{tabular}{|c|c|c|c|}
\hline Mapped Caves of Fort Hood & County & Report Cited In & Biology Studied \\
\hline Plateau Cave No. 2 & Coryell & $\begin{array}{l}15 \text { May } 1991 \\
5 \text { July } 1992 \\
15 \text { February } 1993^{a} \\
10 \text { November } 1992 \\
18 \text { January } 1993 \\
19 \text { July } 1993\end{array}$ & $\begin{array}{l}23 \text { March } 1990 \\
15 \text { January } 1992 \\
4 \text { November } 1992\end{array}$ \\
\hline Roadside Sink & Bell & $\begin{array}{l}5 \text { July } 1992 \\
15 \text { February } 1993^{\text {a }} \\
12 \text { March } 1993 \\
19 \text { July } 1993\end{array}$ & No \\
\hline $\begin{array}{l}\text { Rocket River Cave-Cave Springs } \\
\text { Cave System } \\
\text { (First mapped } 2 \text { January } 1963, \\
\text { later mapped by Warton and As- } \\
\text { sociates) }\end{array}$ & Coryell & $\begin{array}{l}15 \text { May } 1991 \\
5 \text { July } 1992 \\
15 \text { February } 1993 \\
10 \text { November } 1992 \\
18 \text { January } 1993 \\
19 \text { July } 1993 \\
6 \text { December } 1993\end{array}$ & $\begin{array}{l}14 \text { January } 1992 \\
14 \text { \& !6 January } 1992 \\
6 \text { January } 1993 \\
5 \text { November } 1992 \\
6 \text { November } 1992 \\
16 \text { July } 1993\end{array}$ \\
\hline Rugger's Rift Cave & Bell & 19 July $1993^{a}$ & 2 July 1993 \\
\hline Run-off Cave & Coryell & $\begin{array}{l}15 \text { May } 1991 \\
5 \text { July } 1992 \\
15 \text { February } 1993^{b} \\
18 \text { January } 1993^{b}\end{array}$ & $\begin{array}{l}27 \text { January } 1990 \\
28 \text { August } 1991 \\
\text { 14-15 March } 1992\end{array}$ \\
\hline Rusty Bucket Sink & Bell & $\begin{array}{l}5 \text { July } 1992 \\
15 \text { February } 1993^{a} \\
12 \text { March } 1993\end{array}$ & No \\
\hline Saltpetre Cave (map from 1964) & Coryell & $\begin{array}{l}15 \text { May } 1991 \\
5 \text { July } 1992 \\
15 \text { February } 1993\end{array}$ & No \\
\hline $\begin{array}{l}\text { Shell Mountain Bat Cave (map } \\
\text { from 1964) }\end{array}$ & Coryell & $\begin{array}{l}15 \text { May } 1991 \\
5 \text { July } 1992 \\
15 \text { February } 1993 \\
\end{array}$ & $\begin{array}{l}16 \text { March } 1963 \\
8 \text { February } 1992\end{array}$ \\
\hline $\begin{array}{l}\text { Tippet Cave (missing most recent } \\
\text { map) }\end{array}$ & Coryell & $\begin{array}{l}15 \text { May } 1991 \\
5 \text { July } 1992 \\
15 \text { February } 1993 \\
10 \text { November } 1992\end{array}$ & $\begin{array}{l}10 \text { March } 1963 \\
24 \text { January } 1992 \\
4 \text { November } 1992\end{array}$ \\
\hline Treasure Cave & Bell & $\begin{array}{l}5 \text { July } 1992 \\
15 \text { February } 1993^{\text {a }} \\
18 \text { January } 1993 \\
12 \text { March } 1993\end{array}$ & $\begin{array}{l}14 \text { March } 1992 \\
4 \text { December } 1992\end{array}$ \\
\hline Wagon Top Cave & Coryell & $\begin{array}{l}15 \text { May } 1991 \\
5 \text { July } 1992 \\
15 \text { February } 1993 \\
18 \text { January } 1993^{b}\end{array}$ & $\begin{array}{l}21 \text { January } 1992 \\
7 \text { February } 1992\end{array}$ \\
\hline Wagon Top Spring Cave & Coryell & $\begin{array}{l}15 \text { May } 1991 \\
5 \text { July } 1992 \\
15 \text { February } 1993 \\
18 \text { January } 1993^{b} \\
19 \text { July } 1993\end{array}$ & 21 January 1992 \\
\hline Wolf Cave No. 1 (map from 1964) & Coryell & $\begin{array}{l}15 \text { May } 1991 \\
5 \text { July } 1992 \\
15 \text { February } 1993\end{array}$ & No \\
\hline Wolf Cave No. 2 (map from 1964) & Coryell & $\begin{array}{l}15 \text { May } 1991 \\
5 \text { July } 1992 \\
15 \text { February } 1993\end{array}$ & No \\
\hline
\end{tabular}

Source: Contractor reports by Mike Warton \& Associates and James R. Reddell.

${ }^{a}$ Report with the map of that cave.

${ }^{\mathrm{b}}$ Report with most recent map of caves mapped more than once. 
Table 5. Status of biological collections in unsurveyed (interior dimensions not mapped) cave and karst features of Fort Hood.

\begin{tabular}{|c|c|c|c|}
\hline Unmapped Karst Features & County & Report Cited In & Biology Studied \\
\hline Baby Rattler Sink & Coryell & $\begin{array}{l}5 \text { July } 1992 \\
15 \text { February } 1993\end{array}$ & No \\
\hline Back Snapper Cave & Bell & 19 July 1993 & No \\
\hline Bear Creek & & $\begin{array}{l}12 \text { March } 1993 \\
19 \text { July } 1993\end{array}$ & \\
\hline Bear Springs & Bell & $\begin{array}{l}5 \text { July } 1992 \\
15 \text { February } 1993 \\
18 \text { January } 1993 \\
19 \text { July } 1993\end{array}$ & 4 December 1992 \\
\hline Big Crevice & Bell & 12 March 1993 & No \\
\hline Bisected Spring & Coryell & $\begin{array}{l}5 \text { July } 1992 \\
15 \text { February } 1993\end{array}$ & No \\
\hline Briar Cave (map missing) & Coryell & $\begin{array}{l}5 \text { July } 1992 \\
15 \text { February } 1993 \\
18 \text { January } 1993 \\
6 \text { December } 1993\end{array}$ & $\begin{array}{l}15 \text { January } 1992 \\
6 \text { January } 1993-- \text { Noted crayfish }\end{array}$ \\
\hline $\begin{array}{l}\text { B.R.'s Secret Cave (Rocket } \\
\text { River Cave System) }\end{array}$ & Coryell & $\begin{array}{l}5 \text { July } 1992 \\
15 \text { February } 1993 \\
10 \text { November } 1992 \\
19 \text { July } 1993\end{array}$ & $\begin{array}{l}9 \text { February } 1992 \\
5 \text { November } 1992\end{array}$ \\
\hline B.R.'s South Sinks & Bell & 12 March 1993 & No \\
\hline Bumelia Well Cave & Bell & 19 July 1993 & No \\
\hline 1923 Cave & Coryell & $\begin{array}{l}5 \text { July } 1992 \\
15 \text { February } 1993 \\
10 \text { November } 1992 \\
6 \text { December } 1993\end{array}$ & $\begin{array}{l}15 \text { January } 1992 \\
24 \text { and } 27 \text { February } 1992 \\
5 \text { November } 1992\end{array}$ \\
\hline $\begin{array}{l}\text { Cave Springs / East and } \\
\text { West Spring }\end{array}$ & Coryell & $\begin{array}{l}5 \text { July } 1992 \\
15 \text { February } 1993\end{array}$ & 14 and 31 January 1992 \\
\hline Clabber Point Trash Sink & Coryell & $\begin{array}{l}5 \text { July } 1992 \\
15 \text { February } 1993\end{array}$ & 18 September 1991 \\
\hline Cold Springs & Bell & $\begin{array}{l}5 \text { July } 1992 \\
15 \text { February } 1993 \\
18 \text { January } 1993\end{array}$ & 3 December 1992 \\
\hline Fossil Springs Cave & Coryell & $\begin{array}{l}6 \text { December } 1993 \\
19 \text { July } 1993\end{array}$ & No \\
\hline $\begin{array}{l}\text { Gann Cave (map missing) } \\
\text { (Rocket River Cave System) }\end{array}$ & Coryell & $\begin{array}{l}5 \text { July } 1992 \\
15 \text { February } 1993\end{array}$ & 14 January 1992 \\
\hline Hackberry Sink & Coryell & $\begin{array}{l}5 \text { July } 1992 \\
15 \text { February } 1993\end{array}$ & No \\
\hline Mossy Sink & Coryell & $\begin{array}{l}5 \text { July } 1992 \\
15 \text { February } 1993 \\
19 \text { July } 1993\end{array}$ & 14 January 1992 \\
\hline $\begin{array}{l}\text { Plateau Cave No. } 1 / \\
\text { Plateau Cave }\end{array}$ & Coryell & $\begin{array}{l}15 \text { May } 1991 \\
5 \text { July } 1992 \\
15 \text { February } 1993 \\
10 \text { November } 1992\end{array}$ & $\begin{array}{l}23 \text { March } 1990 \\
5 \text { November } 1992 \\
15 \text { January } 1992\end{array}$ \\
\hline Red Ant Cave & Coryell & $\begin{array}{l}5 \text { July } 1992 \\
15 \text { February } 1993\end{array}$ & 28 August 1991 \\
\hline Royalty Ridge Cave & Coryell & $\begin{array}{l}5 \text { July } 1992 \\
15 \text { February } 1993 \\
12 \text { March } 1993\end{array}$ & $\begin{array}{l}24 \text { February } 1992 \\
5 \text { March } 1993\end{array}$ \\
\hline Sledgehammer Cave & Bell & $\begin{array}{l}15 \text { May } 1991 \\
5 \text { July } 1992 \\
15 \text { February } 1993\end{array}$ & 27 January 1990 \\
\hline Trash Sink & Coryell & $\begin{array}{l}5 \text { July } 1992 \\
15 \text { February } 1993\end{array}$ & No \\
\hline Viper Den Cave & Bell & $\begin{array}{l}15 \text { May } 1991 \\
5 \text { July } 1992 \\
15 \text { February } 1993\end{array}$ & 27 January 1990 \\
\hline
\end{tabular}

Source: Contractor reports from Warton \& Associates and James R. Reddell. 
Table 6. Parameters entered into the population viability analyses of the Golden-cheeked Warbler and the Black-capped Vireo presented in Appendix B.

Starting $\mathrm{N}=$ number of breeding birds at start of simulations

$\mathrm{V} \_$_ $=$temporal variance of a given parameter

SAHY = survival rate of AHY (after hatch year) birds

FSY = seasonal fecundity of SY (second year) birds

FASY = seasonal fecundity of ASY (after second year) birds

SHY = Survival rate of HY (hatch year) birds

FAHY = seasonal fecundity of AHY birds

\begin{tabular}{||l|c|c||}
\hline Parameter & Golden-cheeked Warbler & Black-capped Vireo \\
\hline Starting N & 1600 & 500 \\
\hline SHY & 0.50 & 0.43 \\
\hline VSHY Low & 0.0119 & 0.0147 \\
\hline VSHY High & 0.0238 & 0.0294 \\
\hline SAHY & 0.57 & 0.57 \\
\hline VSAHY & 0.01 & 0.01 \\
\hline FSY (males per breeding male) & 0.7535 & N/A \\
\hline VFSY & 0.024 & N/A \\
\hline FASY (males per breeding male) & 1.075 & N/A \\
\hline VFASY & 0.0056 & N/A \\
\hline FAHY & N/A & 1 \\
\hline VFAHY & N/A & 0.0432 \\
\hline
\end{tabular}

${ }^{\mathrm{a}}$ Not applicable for this species. 
Figures

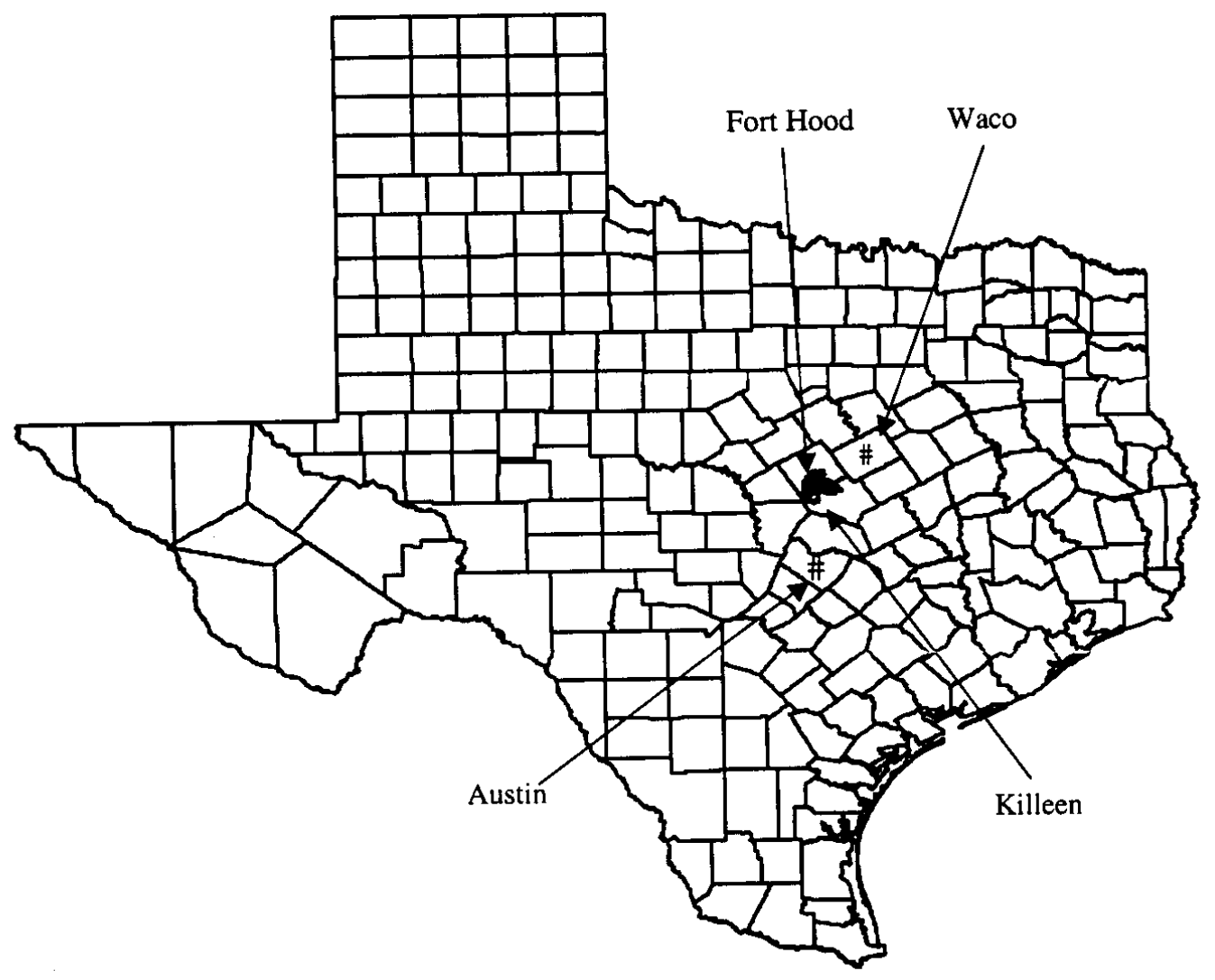

Figure 1. Location of Fort Hood, Texas. 


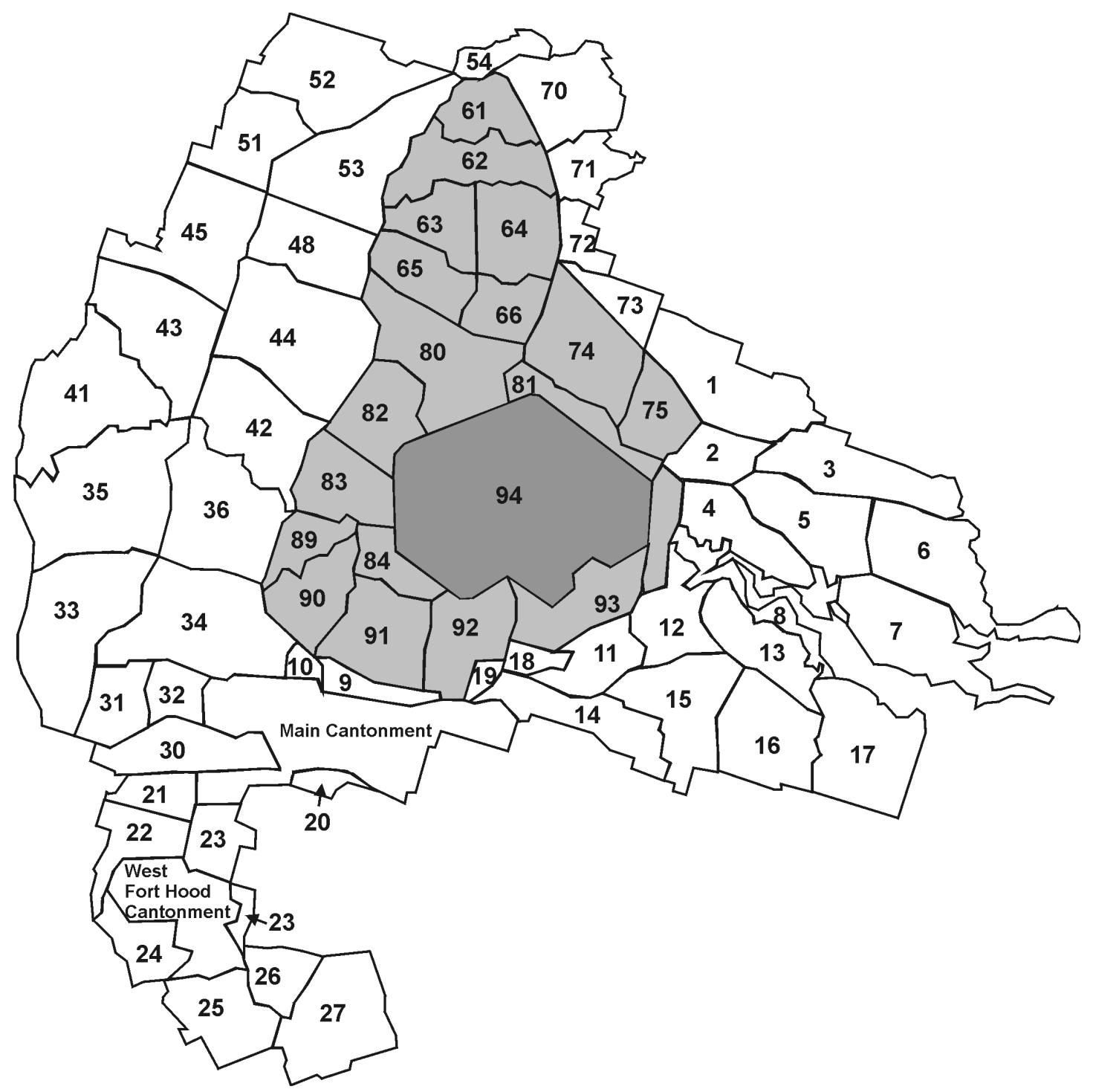

Figure 2. Training area designations on Fort Hood, Texas.

Live-fire ranges overlay is medium gray scale (TAs 61 through 93). Artillery impact area overlay is dark gray scale (TA 94). All other areas unless otherwise noted in the text are available for maneuver training activities. 


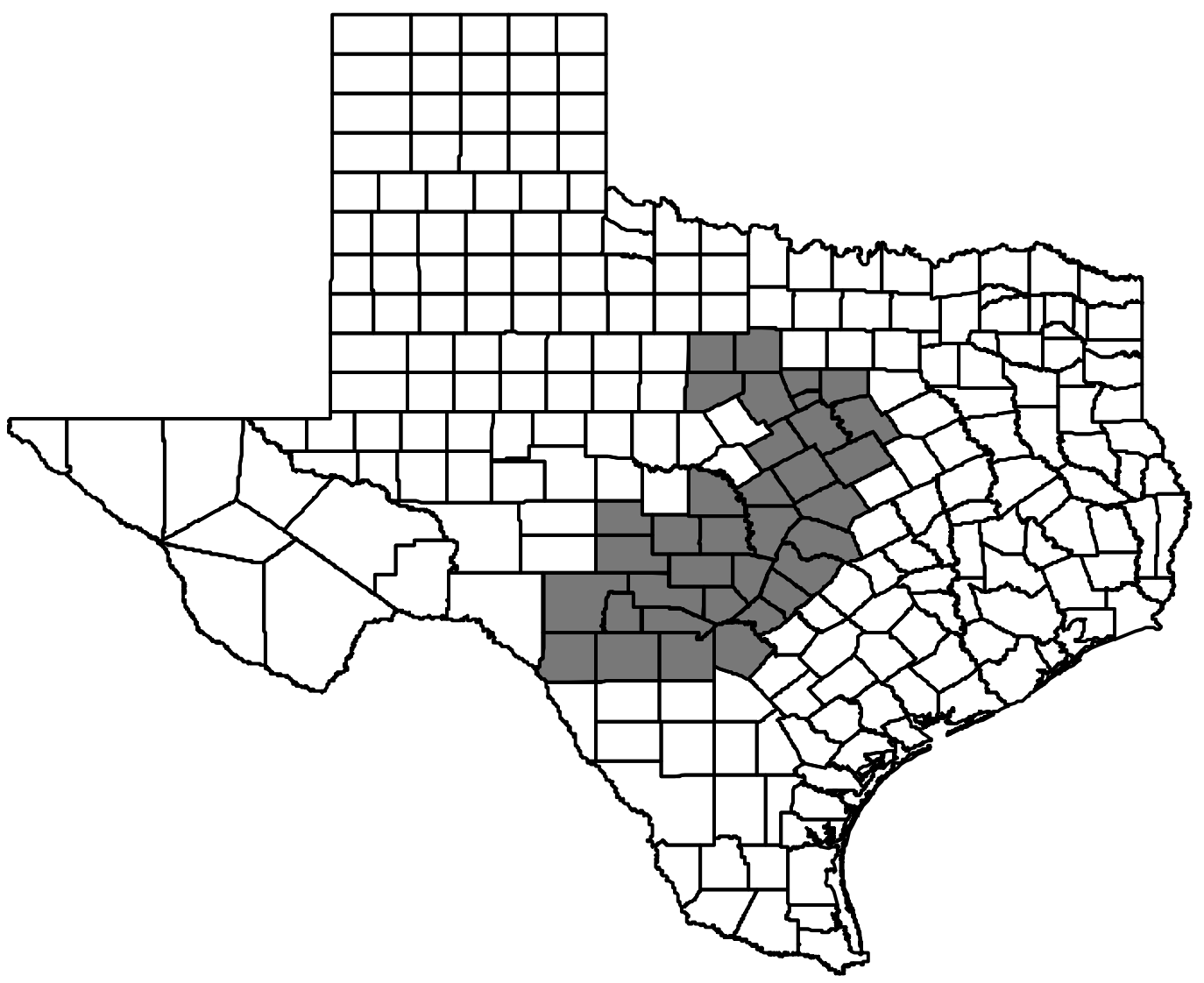

Figure 3. Historical breeding range of golden-cheeked warblers in Texas. 


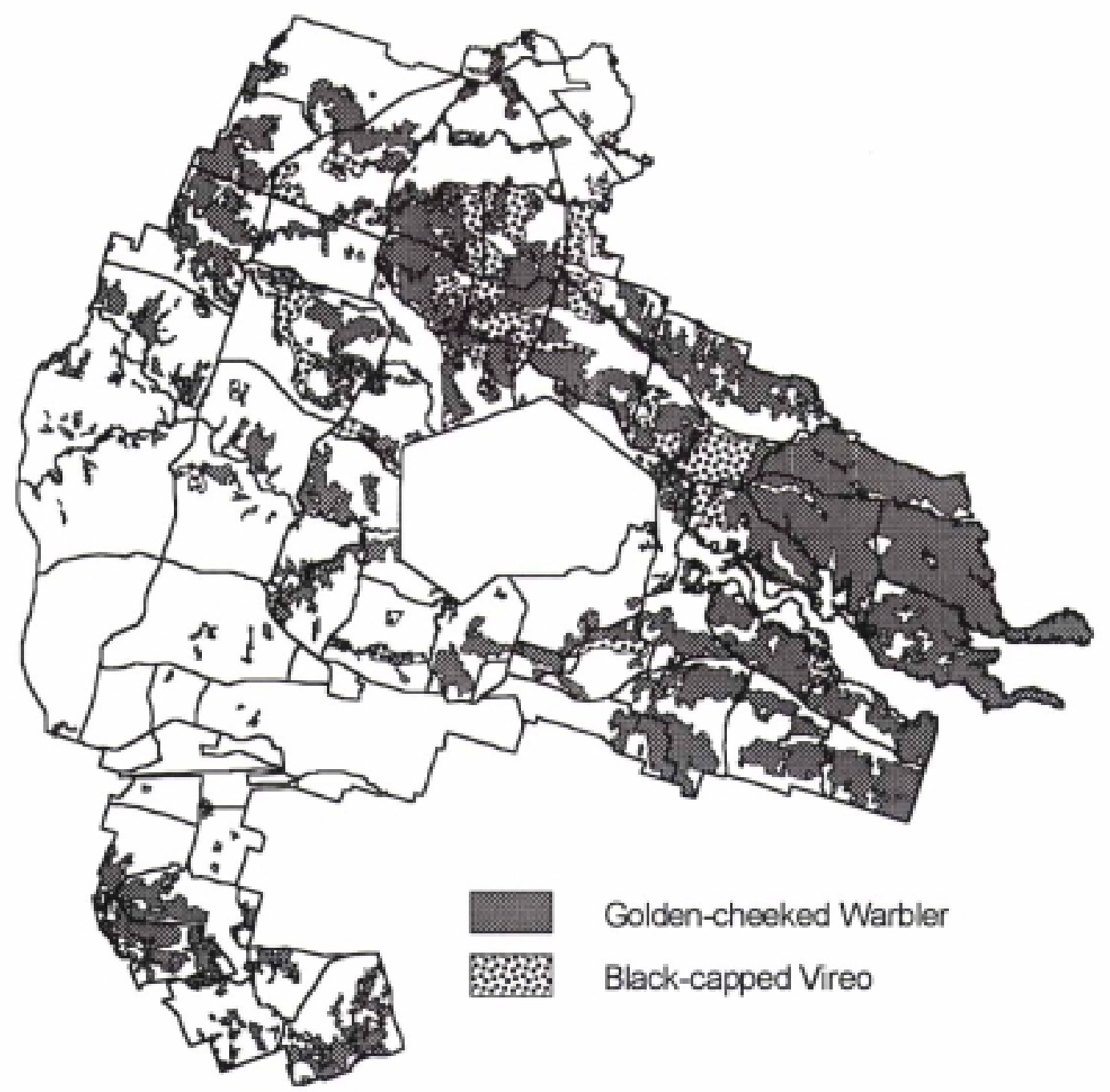

Figure 4. Current distribution of golden-cheeked warbler and black-capped vireo habitat on Fort Hood, Texas.

Habitat determination is based on visual interpretation of aerial photography, known bird locations, and ground surveys. 


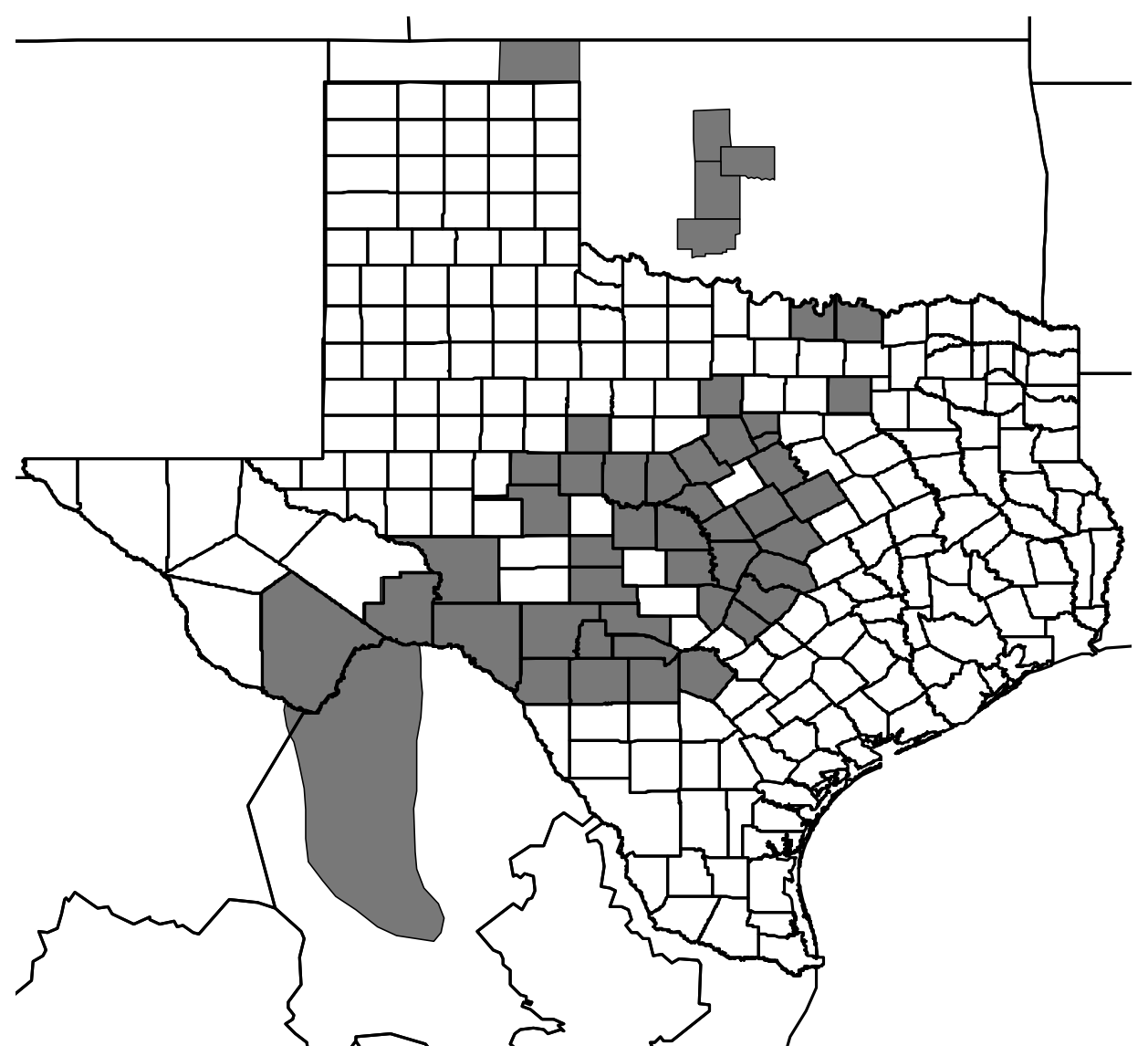

Figure 5. Current breeding range of black-capped vireos. 


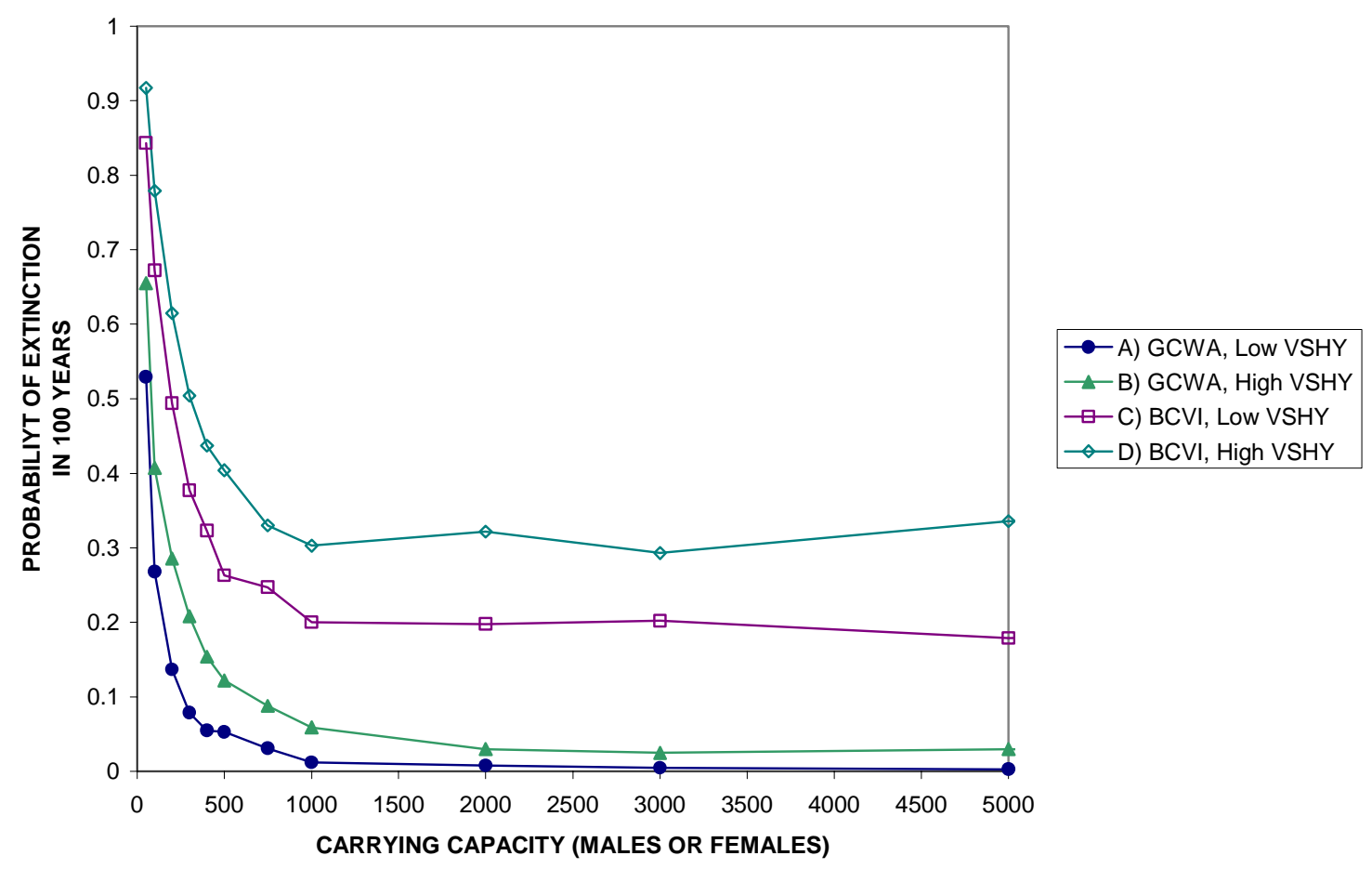

Figure 6. Extinction probability of golden-cheeked warblers and black-capped vireos as a function of carrying capacity of singing males.

Low VSHY = low variance of juvenile survival. High VSHY = high variance of juvenile survival. Carrying capacity represents the maximum potential number of singing males. 


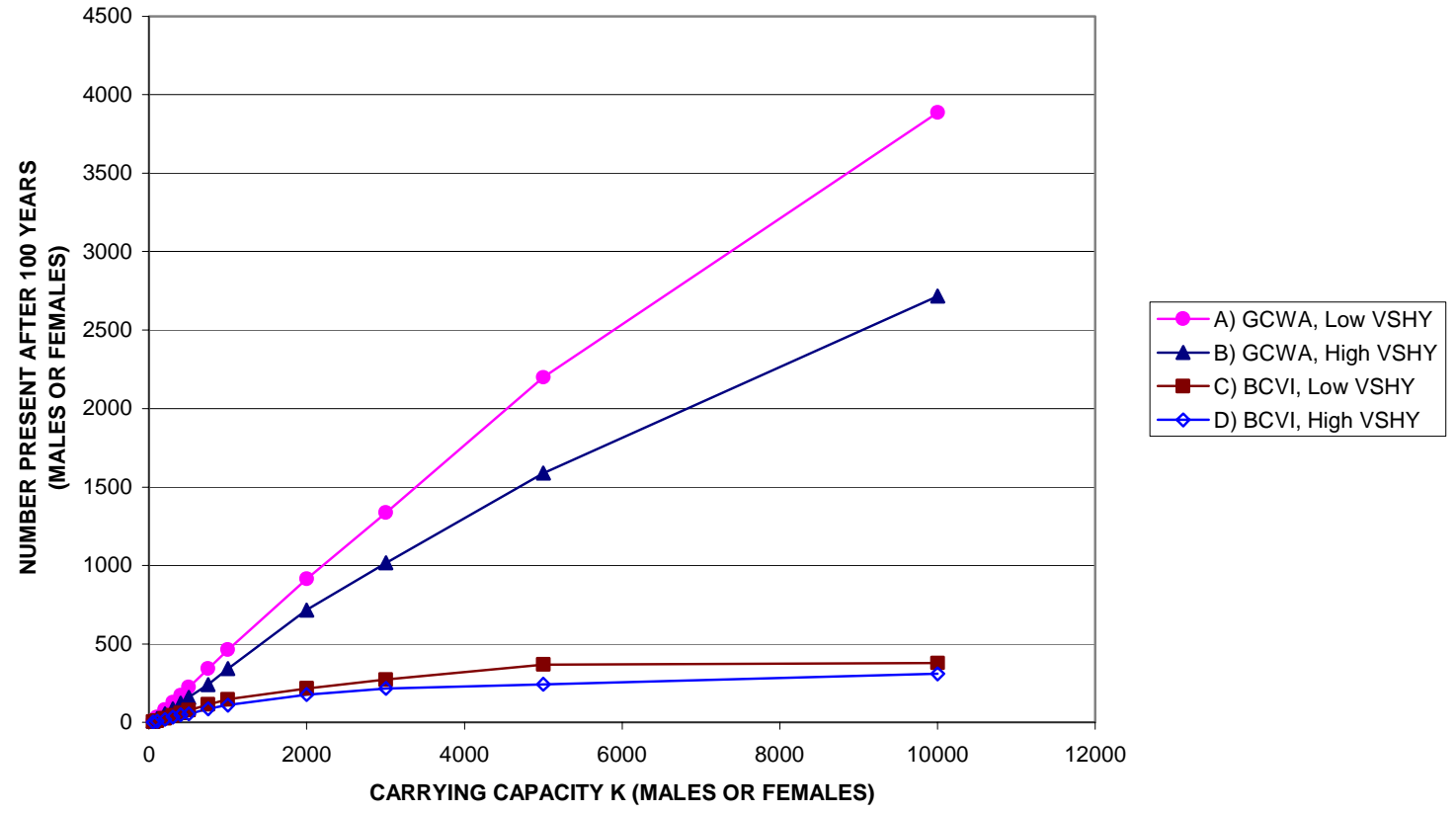

Figure 7. Simulation of estimated black-capped vireo and golden-cheeked warbler population size as a function of carrying capacity.

Low VSHY = low variance of juvenile survival. High VSHY = high variance of juvenile survival. Carrying capacity represents the maximum potential number of singing males. 


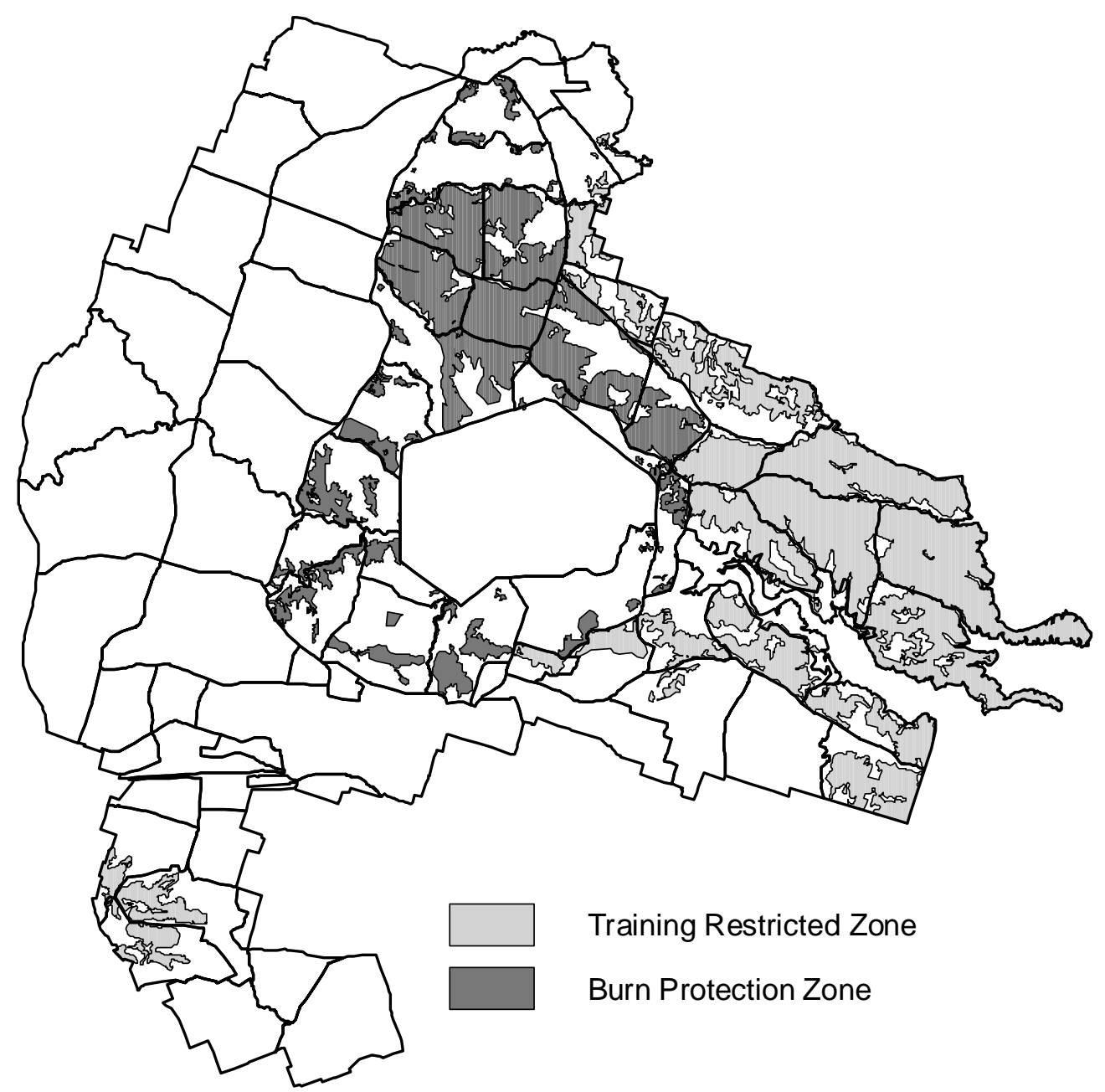

Figure 8. Endangered species overlay for Fort Hood 1:50,000 training area maps.

Golden-cheeked warbler and black-capped vireo habitats subject to training restrictions in maneuver ranges are shown medium gray scale here. Warbler and vireo habitats mapped as "Burn Protection Zones" within Live-fire Training Areas are shown dark gray scale. All other warbler and vireo habitat areas not subject to training restrictions (see text) will not be shown on training area maps for distribution to troops. 


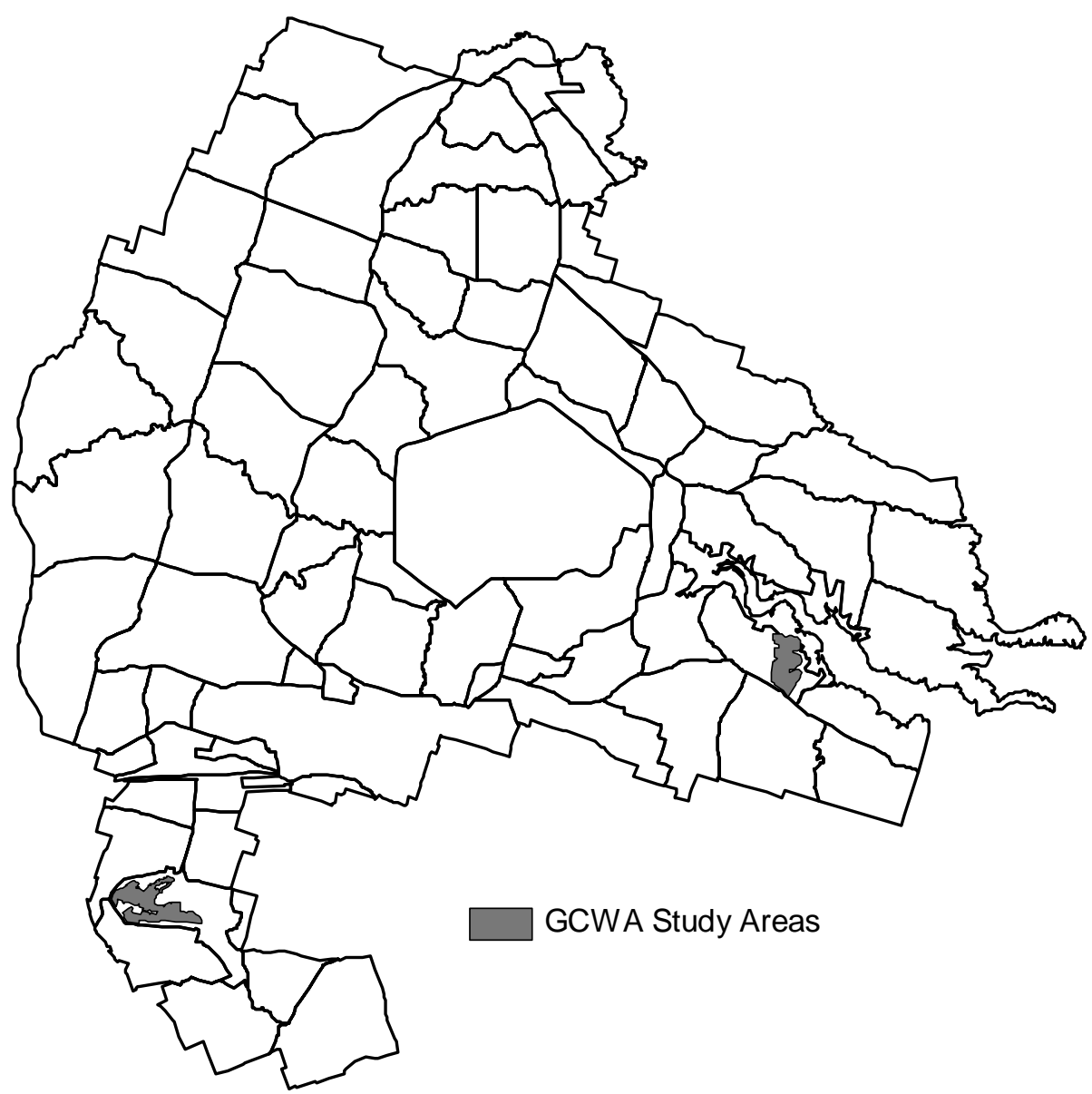

Figure 9. Location of golden-cheeked warbler intensive study areas on Fort Hood, Texas. 


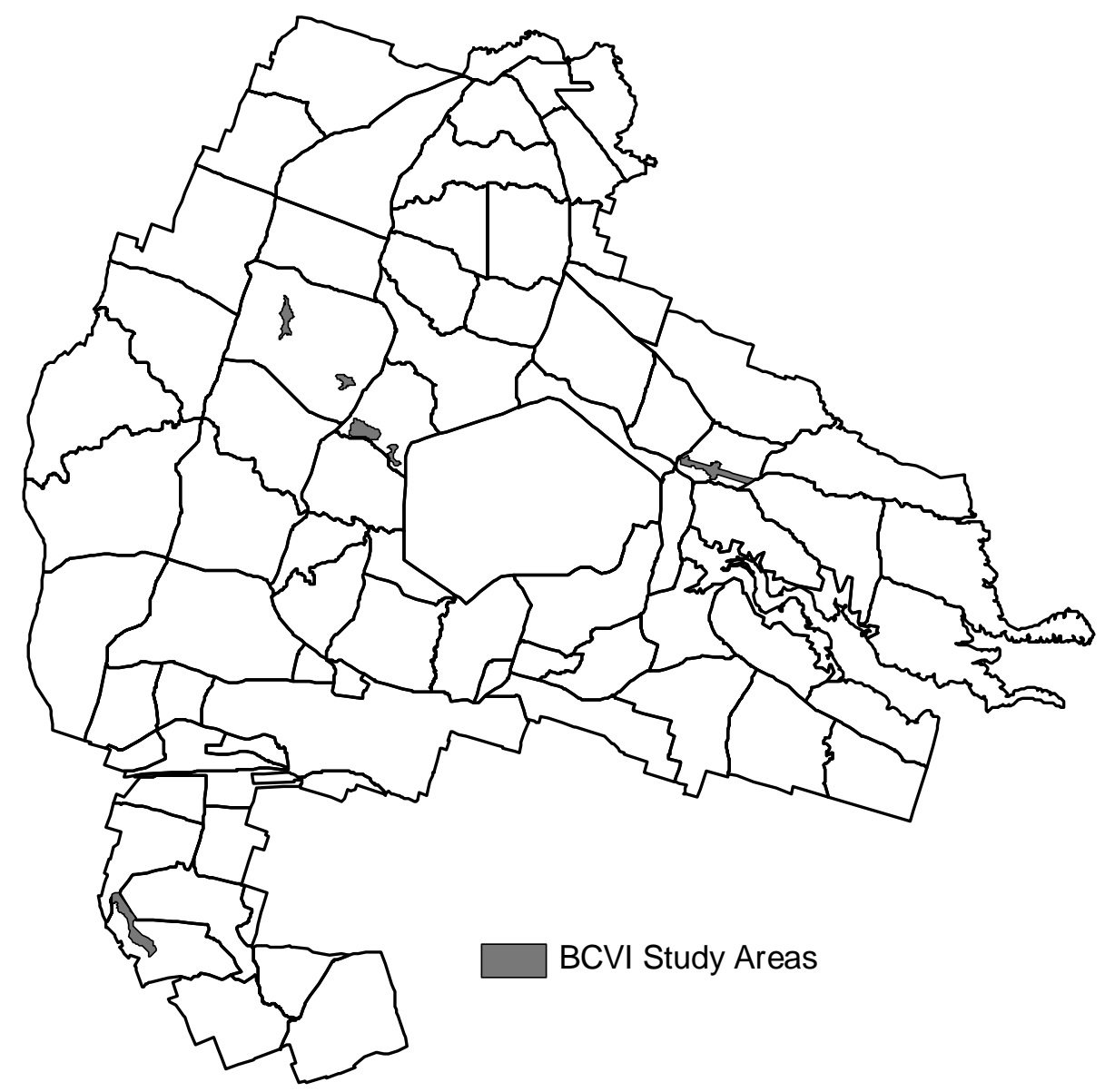

Figure 10. Location of black-capped vireo intensive study areas on Fort Hood, Texas. 


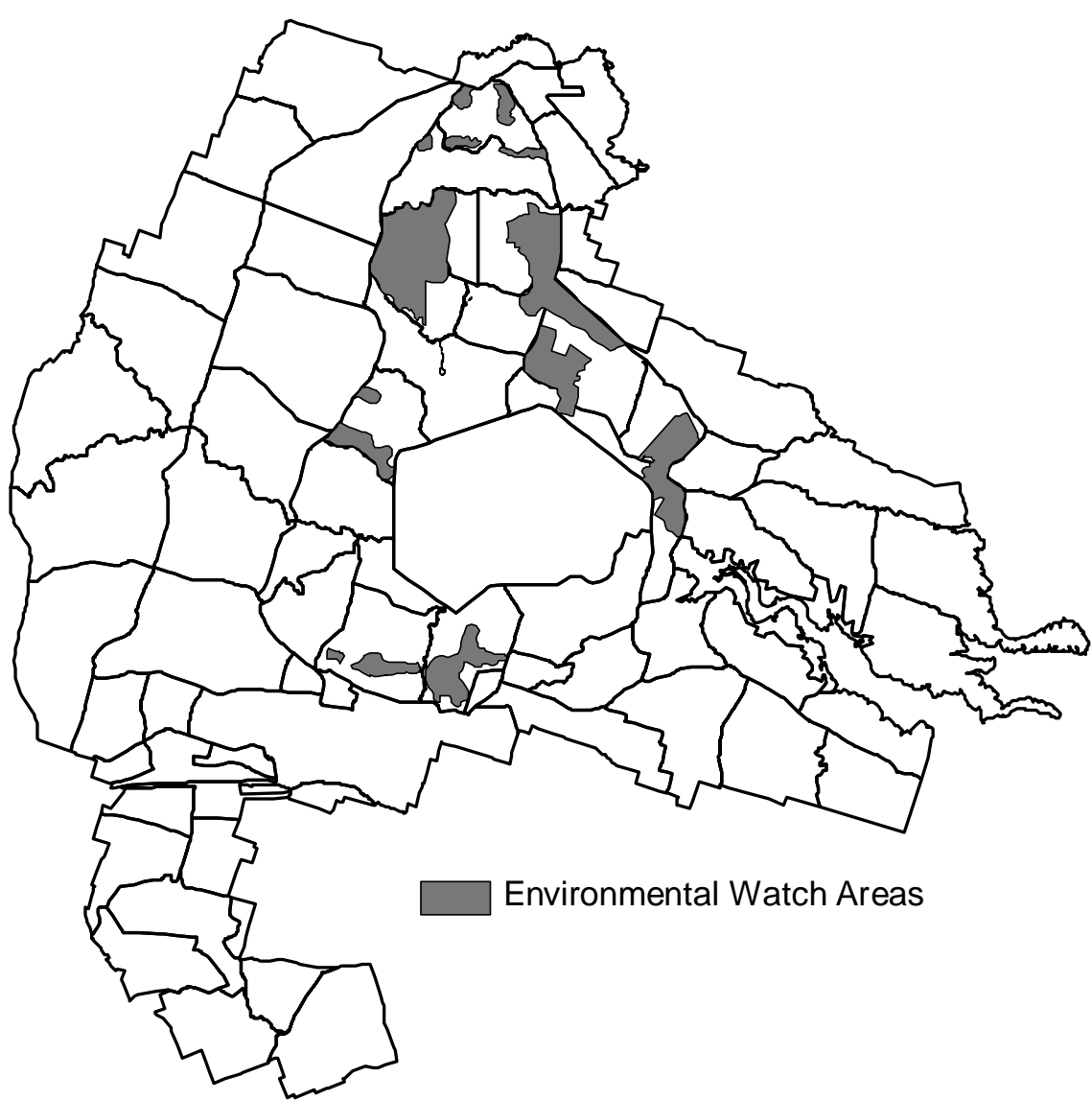

Figure 11. "Environmental Watch Areas" identified by the Fort Hood Natural Resources Branch and G3 for implementation of endangered species monitoring activities in live-fire areas on Fort Hood. 


\section{References}

Akçakaya, H. R. 1994. RAMAS/GI S: Linking Landscape Data with Population Viability Analysis (version 1.0). Applied Biomathematics, Setauket, NY.

American Ornithologists' U nion, Check-List of North American Birds, 6th ed. (Allen Press Inc., Lawrence, KS, 1983).

Andren, H., and P. Angelstrom, "Elevated Predation Rates as an Edge Effect in Habitat Islands: Experimental Evidence," Ecology, Vol 69 (1988), pp 544-547.

Aplet, G.H., et al., "Population and Site Characteristics of a Recently Discovered Disjunct Population of Croton alabamensis," Draft Report (Department of Range Science, Colorado State University, Fort Collins, 1991).

Army Regulation (AR) 200-3, Natural Resources - Land, Forest, and Wil dlife Management, 28 February 1995.

Arnold, K.A., C.L. Coldren, and M.L. Fink. 1996. The interactions between avian predators and Golden-cheeked Warblers in Travis County, Texas. Report no. TX-96/1983-2, Texas Transportation Institute of Texas A\&M University, College Station, TX.

Barber, D.R., and T.E. Martin, "I nfluence of alternate Host Densities on Brown-headed Cowbird parasitism Rates in Black-capped Vireos," Condor, Vol 99 (1997), pp 595-604.

Beardmore, C.J., "Habitat U se of Golden-cheeked Warblers in Travis County, Texas," M.S. thesis (Texas A\&M University, College Station, TX, 1994).

Beardmore, C., J . Hatfield, and J . Lewis (Compilers and Editors), Draft Golden-cheeked Warbler Population and Habitat Viability Assessment (Report of Workshop in Austin, Texas, August 1995).

Beardmore, C., and J . Hatfield (Compilers and E ditors), Draft Black-capped Vireo Population and Habitat Viability Assessment Report (Report of Workshop in Austin, Texas, September 1995).

Benson, R.H., and K.L.P. Benson, "Estimated Size of Black-capped Vireo Population of Northern Coahuila, Mexico," Condor, Vol 92 (1990), pp 777-779.

Benson, R.H., and K.L.P. Benson, "Reply to Scott and Garton," Condor, Vol 93 (1991), pp 470-472.

Braun, M.J ., D.D. Braun, and S.B. Terrill, "Winter Records of the Golden-cheeked Warbler (Dendroica chrysoparia) from Mexico," American Birds, Vol 40 No. 3 (1986), pp 564-566. 
Brewster, W., "On the Habits and Nesting of Certain Rare Birds in Texas," Bulletin of the Nuttall Ornithol ogical Club, Vol 4 (1879), pp 75-80.

Brittingham, M.C., and S.A. Temple, "Have Cowbirds Caused Forest Songbirds to Decline?" Bioscience, Vol 33 (1983), pp 31-35.

Bryan, K.B., and D.K. Stuart, "Black-capped Vireo Project, 1990: Results and Summary," Performance Report Submitted to Texas Parks and Wildlife Department, Project E-1-2 (1990).

Bunker, C.D., "Habits of the Black-capt [sic] Vireo (Vireo Atricapillus)," Condor, Vol 12 (1910), pp 70-73.

Burgman, M.A., S. Ferson, and H.R. Akçakaya, 1993. Risk Assessment in Conservation Biology. Chapman \& Hall, London.

Chambers, S.M., and S. J ahrsdoerfer, "Endangered and Threatened Wildlife and Plants: Final Rule to Determine Five Texas Cave Invertebrates to be Endangered Species," F ederal Register, Vol 53 (1988), pp 36029-36933.

Chapman, F.M., TheWarblers of North America (Dover Publications, Inc., N ew York, 1968).

Coldren, C.L., "The Effects of Habitat F ragmentation on the Golden-cheeked Warbler" (Ph.D. dissertation, Texas A\&M University, College Station, TX, 1998).

Deignan, H.G., "Type Specimens of Birds in the United States National Museum," Bulletin of the U.S. National Museum, Vol 221 (1961), pp 1-718.

Diamond, D., "Plant communities of Texas - series level" (Unpublished manuscript, Texas Parks and Wildlife Department, 1992).

Diersing, V.E., W.D. Severinghaus, and E.W. Novak, Annotated Directory of Endangered Wildlife on Selected U.S. Army Installations West of the Mississippi River, TR N-85/08/ADA154623 (USACERL, March 1985).

Dresser, H.E., "Notes on the Birds of Southern Texas," I bis, Vol 1 (1865), pp 466-495.

Engels, T.M., and C.W. Sexton, "Negative Correlation of Blue J ays and Golden-cheeked Warblers near an U rbanizing Area," Conservation Biology, Vol 8 No. 1 (1994) pp 286-290.

Farmer, J .A., "An E cological Life History of Croton alabamensis E.A. Smith ex Chapman," Ph.D. dissertation (University of Alabama, 1962).

Farmer, J .A., and J .L. Thomas, "Disjunction and E ndemism in Croton al abamensis," Rhodora, Vol 71 (1969), pp 94-103.

Gates, J .E., and L.W. Gysel, "Avian Nest Dispersion and Fledging Success in Field-Forest E cotones," Ecol ogy, Vol 59 (1978), pp 871-883. 
Gilpin, M.E., and M. Soule, 1986. Minimum viable populations: processes of species extinction. In Conservation Biology: The Science of Scarcity and Diversity. M. Soule [Ed.], Sinauer Associates, Inc., Sunderland, MA, pp 19-34.

Ginzbarg, S., "A N ew Disjunct Variety of Croton alabamensis (Euphorbiaceae) from Texas," SIDA Vol 15, No. 1 (1992), pp 41-52.

Goodman, L.A., 1960. On the exact variance of products. J ournal of the American Statistical Association, 55:708-713.

Graber, J .W., "Distribution, Habitat Requirements, and Life History of the Black-capped Vireo (Vireo atricapilla)," Ecological Monographs, Vol 31 (1961), pp 313-336.

Graber, J .W., "A Bioecol ogical Study of the Black-capped Vireo (Vireo atricapillus)," Ph.D. dissertation (University of Oklahoma, N orman, OK, 1957).

Grzybowski, J .A., "I Interim Report: Population and Nesting Ecology of the Black-capped Vireo (Vireo atricapillus)," Report submitted to the Office of Endangered Species, USFWS, Albuquerque, NM (1986).

Grzybowski, J .A., "Performance Report: Population and Nesting Ecology of the Black-capped Vireo (Vireo atricapillus) in Oklahoma," Report submitted to the Oklahoma Department of Wildlife Conservation, Oklahoma City, OK (1987).

Grzybowski, J .A., "Performance Report: Population and Nesting Ecology of the Black-capped Vireo (Vireo atricapillus) in Oklahoma," Report submitted to the Oklahoma Department of Wildlife Conservation, Oklahoma City, OK (1988).

Grzybowski, J .A., "Report: Ecology and Management of the Black- capped Vireo (Vireo atricapilIus) in the Wichita Mountains, Oklahoma," Submitted to USFWS, Wichita Mountains National Wildlife Refuge, Indiahoma, OK (1989a).

Grzybowski, J .A., "I nterim Report: Black-capped Vireo Investigations: Population and Nesting Ecology," Report submitted to USFWS, Office of Endangered Species, Albuquerque, NM (1989b).

Grzybowski, J .A., "Final Report: Population and Nesting Ecology of the Black-capped Vireo in Texas-1988-1989)," Report submitted to USFWS, Arlington E cological Services, Arlington, TX (1990).

Grzybowski, J .A., "Black-capped Vireo (Vireo atricapillus)" TheBirds of N orth America, No. 181 (A. Poole and F. Gill, eds.). The Academy of Natural Sciences, Philadel phia, and theAmerican Ornithologists' U nion, Washington, DC (1995).

Grzybowski, J .A., R.B. Clapp, and J .T. Marshall, J r., "History and Current Population Status of the Black-capped Vireo in Oklahoma," American Birds, Vol 40 (1986), pp 1151-1161.

Grzybowski, J .A., G.D. Schnell, and D.J . Tazik, Regional Analysis of Black-capped Vireo Habitats (Southwestern Association of Naturalists, Denton, TX, April 1990). 
Grzybowski, J .A., D.J . Tazik, and G.D. Schnell, "Regional Analysis of Black-capped Vireo Breeding habitats," Condor, Vol 96, No. 2 (1994), pp 512-544.

Hayden, T.J ., D.J . Tazik, R.H. Melton, and J .D. Cornelius, "Cowbird Control Program at Fort Hood, Texas: Lessons for Mitigation of Cowbird Parasitism on a Landscape Scale," I n, Ecology and Management of Cowbirds and Their Hosts: Studies in the Conservation of North American Passerine Birds (J . Smith, T. Cook. S. Rothstein, S. Robinson, and S. Sealy, Eds.). The University of Texas Press, Austin, TX (2000), pp 357-370.

Huss, D.L., "F actors I nfluencing Plant Succession Following Fire in Ash J uniper Woodland Types in Real County, Texas," M.S. Thesis (Texas A\&MM University, 1954).

J ahrsdoerfer, W.S., “Endangered and Threatened Wildlife and Plants: Proposed Rules To List the Golden-cheeked Warbler as Endangered," Federal Register, Vol 55 (1990), pp 18846-18849.

J ette, L.A., T.J . Hayden, and J .D. Cornelius. 1998. Demographics of the Golden-cheeked Warbler (Dendroica chrysoparia) on Fort Hood, Texas." Submitted to HQ III Corps and Fort Hood.

J ohnson, K.W., et al., "Sightings of Golden-cheeked Warblers (Dendroica chrysoparia) in Northeastern Mexico," Wil son Bulletin, Vol 100, No. 1 (1988), pp 130-131.

J ohnston, M.C., W.L. Thompson, and E. Kincaid, J r., "Breeding Bird Census: 37, J uniper-Oak Woods on Limestone Hills," Audubon Field Notes, Vol 6 (1952), pp 323-324.

Koloszar, J .A., and J .S. Horne, 2000. "The spatial and temporal response of brown-headed cowbirds to a reduction in cattle stocking rates - final analysis." Pages 147-178 in Endangered species monitoring and management at Fort Hood, Texas: 1999 annual report. Fort Hood Project, The Nature Conservancy of Texas, F ort Hood, TX.

Kral, R., Report on Rare, Threatened, or Endangered Forest Related Vascular Plants of the South, TR R8-TT2 (U.S. Forest Service [USFS], 1983).

Kroll, J .C., "Habitat Requirements of the Golden-cheeked Warbler: Management I mplications," J ournal of Range Management, Vol 33, No. 1 (1980), pp 60-65.

Ladd, C.G., "Nesting Habitat Requirements of the Golden-cheeked Warbler," M.S. thesis (Southwest Texas State University, 1985).

Ladd, C.G., and L. Gass, 1999. "Golden-cheeked Warbler (Dendroica chrysoparia)" in The Birds of North America, No. 420 (A. Poole and F. Gill, eds.). The Birds of N orth America, Inc., Philadelphia, PA.

Lyons, J., "Winter Habitat Survey of the Golden-cheeked Warbler (Dendroica chrysoparia) in Guatemala," Report submitted to the Resource Protection Division, Texas Parks and Wildlife (Austin, TX, 1990).

Lytle, K.M., “The Golden-cheeked Warbler A Literature Review,” M.A. report (University of Texas at Austin, 1994). 
Maas-Burleigh, D.S., 1997. "Summary of the 1995 and 1996 field seasons: Effects of habitat fragmentation on Golden-cheeked Warblers (Dendroica chrysoparia)." (Unpublished, available from ERDC/CERL.)

Marshall, J .T., R.B. Clapp, and J .A. Grzybowski, "Status Report: Vireo atricapillus, Woodhouse, Black-capped Vireo," report submitted to USFWS, Office of Endangered Species, Albuquerque, NM (1985).

McDaniel, S., "Status Report on Croton al abamensis," white paper prepared for the Endangered Species Office, USFWS (USFWS, Atlanta, GA, 1981).

Melton, R.H., D.J . Tazik, and J .D. Cornelius, "Nest-site Selection and Nesting Habitat Quality in the Black-capped Vireo on Fort Hood Military Reservation, Texas" (Unpublished manuscript, USACERL, Champaign, IL, 1995).

Mengel, R.M., "The Probable History of Species Formation in Some Northern Wood Warblers," Living Bird, Vol 3 (1964), pp 9-43.

Mohr, C.A., "New or Little Known Plants, the Last Addition to the Shrubs of Eastern North America (Croton alabamensis)," Garden and Forest, Vol 2 (1889), pp 592, 594.

Nice, M.M., "Studies in the Life History of the Song Sparrow, I: Population Study of the Song Sparrow," Transactions of the Linnean Society, Vol 4 (New York, 1937), pp 1-247.

Nolan, V., J r., "The Ecology and Behavior of the Prairie Warbler, Dendroica discolor, Ornithological Monographs No. 26 (The American Ornithologists' Union, 1978).

Oberholser, H.C., The Bird Life of Texas (The University of Texas Press, Austin, 1974).

O'Neal, K.G., J .T. Baccus, W.E. Armstrong, and D.E. Harmel, "Effects of Prescribed Burning on Black-capped Vireo Habitat and Territory Establishment," Trans. 61st North American Wildlife and Natural Resource Conference (1996).

Pease, C.M., and L.G. Gingerich, "The Habitat Requirements of the Black-capped and Goldencheeked Warbler Populations Near Austin, Texas," Final report prepared for the Biological Advisory Team (Austin Regional Habitat Conservation Plan, 1989).

Perrigo, G., et al., "Spring Migration Corridor of Golden-cheeked Warblers in Tamaulipas, Mexico," American Birds, Vol 40, No. 1 (1990), p 28.

Pulich, W.M., TheGolden-cheeked Warbler: A Bioecological Study (Texas Parks and Wildlife Dept., Austin, 1976).

Ratzlaff, A., "Endangered and Threatened Wildlife and Plants; Determination of the Black-capped Vireo to be an Endangered Species," Federal Register, Vol 52 (1987), pp 37420-37423.

Robbins, C.S., D.K. Dawson, and B.A. Dowell, "Habitat Area Requirements of Breeding Forest Birds of the Middle Atlantic States," Wildlife Monographs, No. 103 (Wildlife Society, 1989). 
Robinson, S.K., S.I. Rothstein, M.C. Brittingham, L.J . Petit, and J .A. Grzybowski, "Ecology and Behavior of Cowbirds and their I mpact on Host Populations," Pp 428-460 in T.E. Martin and D.M. Finch, Eds. Ecology and Management of Neotropical Migratory Birds. A Synthesis and Review of Critical Issues, Oxford University Press, New York (1995).

Sclater, P.L., and O. Salvin, "Character of Eleven New Species of Birds Observed by Osbert Salvin in Guatemala," Proceedings of the Zool ogical Society of London, Part 28 (1860), p 298.

Scott, J .M., and E.O. Garton, "Population Estimates of the Black-capped Vireo," Condor, Vol 93 (1991), pp 469-470.

Shull, A., "Endangered and Threatened Wild ife and Plants: Proposal to Determine the Blackcapped Vireo To Be an Endangered Species," Federal Register, Vol 51 (1986), pp 44808-44812.

Simmons, G.F., Birds of theAustin Regi on (University of Texas Press, Austin, 1924).

Smith, A.P., "Additions to the Avifauna of Kerr County, Texas," Auk, Vol 33 (1916), pp 187-193.

Stewart, R.E., and J .W. Aldrich, "Removal and Repopulation of Breeding Birds in a Spruce-fir Forest Community," Auk, Vol 68 (1951), pp 471-482.

Tazik, D.J ., "Proactive Management of an Endangered Species on Army lands: The Black-capped Vireo on the Lands of Fort Hood, Texas," Ph.D. thesis (University of Illinois, Urbana, 1991).

Tazik, D.J ., J .D. Cornelius, and C.A. Abrahamson, Status of the Black-capped Vireo at F ort Hood, Texas, Volumel: Distribution and Abundance, USACERL Technical Report (TR) EN-94/01, Vol I, ADA275757 (1993a).

Tazik, D.J ., J .A. Grzybowski, and J .D. Cornelius, Status of the Black-capped Vireo at F ort H ood, Texas, Volumell: Habitat, USACERL TR EN-94/01, Vol II, ADA275677 (1993b).

Tazik, D.J . and J .D. Cornelius, Status of the Black-capped Vireo at F ort Hood, Texas, VolumellI: Habitat, USACERL TR EN-94/01, Vol III, ADA277544 (1993).

Tazik, D.J ., J .D. Cornelius, D.M. Herbert, T.J . Hayden, and B.R. J ones, Biological Assessment of the Effects of Military Associated Activities on Endanger ed Species at F ort Hood, Texas, USACERL Special Report EN-93/01/ADA263489 (1992).

The Nature Conservancy, Summary of 1997 Research Activities, Texas Conservation Data Center, The Nature Conservancy, F ort Hood, TX (1998), 314 pp.

Thompson, D.E., Observations of Golden-cheeked Warblers Wintering in Guatemala and Honduras. Final Report to U.S. Fish and Wildlife Service, Austin, TX, Cooperative Agreement No. 144800002-94-0846. $68 \mathrm{pp}$ (1995).

Thompson, F.R. III, "Temporal and Spatial Patterns of Breeding Brown-headed Cowbirds in the Midwestern United States," Auk, Vol 111 No. 4 (1994), pp 979-990.

Tordoff, H.B., Checklist of the Birds of Kansas, University of Kansas Museum of Natural History Publication 8 (1956), pp 307-359. 
U.S. Fish and Wildlife Service (USFWS), Black-capped Vireo (Vireo atricapillus) Recovery PIan (USFWS, Arlington E cological Services, Arlington, TX, 1991).

U.S. Fish and Wildlife Service, Golden-cheeked Warbler (Dendroica chrysoparia) Recovery PIan (USFWS, Albuquerque, NM, 1992).

U.S. Fish and Wildlife Service, Recovery PIan for Endangered Karst Invertebrates in Travis and Williamson Counties, Texas (USFWS, Albuquerque, NM, 1994).

U.S. Fish and Wildlife Service, "Black-capped Vireo Population and Habitat viability Assessment Report," compiled and edited by Carol Beardmore, J eff Hatfield, and J im Lewis in conjunction with workshop participants. Report of a September 18-21, 1995 workshop arranged by the U.S. Fish and Wildlife Service in partial fulfillment of U.S. National Biological Service Grant No. 80333-1423. Austin, TX (1996).

U.S. Fish and Wildlife Service, "Golden-cheeked Warbler Population and Habitat viability Assessment Report," compiled and edited by Carol Beardmore, J eff Hatfield, and J im Lewis in conjunction with workshop participants. Report of an August 21-24, 1995 workshop arranged by the U.S. Fish and Wildlife Service in partial fulfillment of U.S. National Biological Service Grant No. 80333-1423. Austin, TX (1996).

Vidal, R.M, C. Macías-Caballero, and C.D. Duncan, "The Occurrence and E cology of the Goldencheeked Warbler in the Highlands of Northern Chiapas, Mexico," Condor, Vol 96 No. 3 (1994), pp 684-691.

Wahl, R., D.D. Diamond, and D. Shaw, The Golden-cheeked Warbler: A Status Review, Report submitted to the E cological Services, USFWS, Fort Worth, TX (1990).

Walters, C., Adaptive Management of Renewable Resources (MacMillan Publishing Company, 1986).

Weinberg, H.J ., Results of the 1997 Golden-cheeked Warbler and Black-capped Vireo Monitoring Program on Camp Bullis, Texas, USACERL Technical Report 98/61/ADA341854 (1998).

Weinberg, H.J ., T.J . Hayden, and J .D. Cornelius, Local and Installation-wide Black-capped Vireo Dynamics on the Fort Hood, Texas Military Reservation, USACERL Technical Report 98/54/ ADA341156 (1998).

Wharton, R.A., E.G. Riley, M.A. Quinn, J .B. Woolley, J .S. Schaffner, and H.R. Burke, 1996. Invertebrate species available as food for the Golden-cheeked Warbler in its nesting habitat. Report no. TX-96/1983-3F Texas Transportation Institute of Texas A\&M University, College Station, TX.

Wilcove, D.S., "Nest Predation in Forest Tracts and the Decline of Migratory Songbirds," Ecology, Vol 66 (1985), pp 1211-1214.

Woodhouse, S.W., "Descriptions of New Species of the Genus Vireo, Vieill, and Zonotrichia Swains," Proceedings of the Academy of Natural Sciences of Philadel phia, Vol 6 (1852), pp 1-60. 



\section{Appendix A: U.S. Fish and Wildlife Service Biological Opinion for Fort Hood, Texas, July 26, 2000}




\title{
United States Department of the Interior
}

\author{
FISH AND WILDLIFE SERVICE \\ 10711 Burnet Road, Suite 200 \\ Austin, Texas 78758 \\ (512) 490-0057 \\ Fax: (512)490-0974
}

July 26,2000

Cons. \# 2-15-93-F-003

Commanding General

LTG Leon J. LaPorte

Department of the Army

Headquarters III Corps and Fort Hood

Fort Hood, Texas 76544

Dear General LaPorte:

The U.S. Fish and Wildlife Service (Service), under section 7 of the Endangered Species Act (Act), is amending its September 23, 1993 Biological Opinion (Opinion) on activities at the Fort Hood Military Reservation, Coryell and Bell Counties, Texas (USFWS 1993), to incorporate (!) Fort Hood's Public Comment Draft 99-03 and Revised Draft 00-04 Endangered Species Management Plan (ESMP) (Hayden et al. 1998, 2000) expected to be finalized within ninety (90) days of this Biological Opinion Amendment, (2) impacts from the February 1996 fires, (3) additional measures to minimize brown-headed cowbird (Molothrus ater) parasitism on endangered goldencheeked warbler (Dendroica chrysoparia) and endangered black-capped vireo (Vireo atricapillus) populations due to grazing programs on Fort Hood, (4) off-road vehicle recreation, and (5) juniper management. In the event that the ESMP is not finalized within the specified period of time, Fort Hood will re-initiate consultation with the Service.

This represents the third amendment to the Opinion. The first amendment (letters dated January 20, 1999 and February 11, 1999) provided interim authorization for "intentional" takings (from construction projects) of warbler and vireo habitat as part of the total incidental take authorized in the Opinion, until this amendment covering the ESMP was finalized. This third amendment updates the following pertinent sections of the 1993 Opinion to incorporate new developments and the activities listed above :

1) Background Information;

2) Project Description;

3) Listed Species Affected;

4) Other Species of Concern;

5) Impacts of the Actions;

6) Reasonable and Prudent Measures (RPM);

7) Terms and Conditions (T\&C); and

8) Conservation Measures.

This third amendment also supersedes the following sections of the 1993 Biological Opinion:

1) Incidental Take Statement;

2) Terms and Conditions \#3f;

3) Terms and Conditions \#4a; and

4) The first amendment (letters dated January 20, 1999 and February l l, 1999).

The second amendment (dated March 12, 1999) covered the loss of 10 hectares (ha) of warbler habitat within the Ammunition Storage Point on West Fort Hood. 
This amendment is based on information provided in the ESMP, the "Fort Hood Vegetative Resource Inventory" (Natural Resources Conservation Service (NRCS) 1998), numerous site visits, and telephone conversations between Service biologists and Fort Hood personnel from the Natural Resources Management Branch of the Environmental Division Office, the Staff Judge Advocate's Office, and G3 Range Control Division. An administrative record of this consultation is on file in the Austin Fish and Wildlife Service Office.

\section{BACKGROUND INFORMATION}

\section{February 1996 Fires}

Three major fires occurred on portions of Fort Hood on February 21, 22, and 23, 1996. The fires originated in the Live Fire Area (Figure 2 of the ESMP) during routine training events under conditions (low humidity and strong winds) that resulted in a very hot crown fire. Approximately $75 \%$ of the burned area was described as Burn Severity Index Level 1 or 2, the most severe burn ratings on the scale developed by the National Park Service (1992). Visible characteristics of Level 1 intensity sites include complete consumption of litter and duff layers, leaving fine white ash, and consumption of all above-ground plant parts, leaving only major stems and trunks.

The February 1996 fires exceeded the annual incidental take authorized in the 1993 Opinion for both the vireo and the warbler. About 2,313 ha of warbler habitat was eliminated, exceeding the authorized incidental take ( 44 ha) by a factor greater than 50 . Because the warbler occupies a mature woodland community and regeneration time takes many $(\geq 25)$ years, impacts to this species are long term. Habitat regeneration time is much more rapid for the vireo (2-5 years), which occupies a mid-successional stage vegetation community. Thus, although an estimated 415 ha of vireo habitat was also lost during the fires (almost 7 times the $60 \mathrm{ha}$ of authorized incidental take), the 2,313 ha of warbler habitat that burned are expected to provide suitable habitat for the vireo within 2 to 5 years. In fact, vireos were observed in portions of the burned areas during the 1998 nesting season and are continuing to expand their use of those areas (J. Comelius, pers. com. 1999).

In addition to direct fire damage, indirect damage to species and their habitats also occurred. A limited amount of damage to vireo and warbler habitat occurred while crews cleared fire breaks to stop the fire. Some existing trails in Training Areas (TAs) 2 and 3 were widened and resuited in a loss of approximately 25 ha of warbler habitat and 6 ha of vireo habitat. The loss of vegetational cover from the watershed of several caves that occur in the burned area, which contain rare and undescribed fauna, potentially have altered normal nutrient flow, siltation rates, and cave microclimates. Approximately $80 \%$ of the largest known population of Texabama croton (Croton alabamensis var. texensis), a species of concen located in TAs 2 and 3, was burned, but has shown some capability to re-sprout from rootstock. Presently, there appears to have been a $100 \%$ recovery of the population in the bumed areas (J. Cornelius, pers. com. 1999).

The Natural Resources Management Branch immediately notified the Austin Fish and Wildlife Service Office of the fires by telephone on February 21 and February 29, 1996. The Director of Public Works provided formal written notification on March 6, 1996 and requested reinitiation of consultation under section 7 of the Act (50 CFR 42). A period of informal consultation ensued. During this period, Fort Hood updated and revised its fire management and control policies and initiated research to evaluate the effects of the fires on the vireo and the warbler. These preventative and remedial measures are incorporated into, and are identified as a primary objective of, Chapter 1 of the ESMP.

In response to the 1996 fires, Fort Hood currently has a fire danger rating system in place to alert trainers when pyrotechnic operations should be limited (Range Condition Amber) or halted (Range Condition Red) based on current (daily) weather and estimated moisture content of vegetation and soil. This system (OPLAN 8-93, "Operation Brush Fire") is fully outlined in Appendix B of the ESMP (FH Reg. 350-40, para. D-6-1). 
Units may request waivers to use incendiary munitions, pyrotechnics, and/or tracers during Range Condition Red no later than $2 \mathrm{l}$ days before a unit is to conduct training. The waiver request is submitted to Range Control (G3) and includes: (1) the date of the event; (2) the type of incendiary munitions, pyrotechnics, or tracers; (3) the type and number of vehicles, to include main gun munitions for the event; (4) the type of fire fighting equipment available and their capabilities; (5) that the unit considered target selection so that firing into endangered specics habitat would be minimized, and; (6) the impact an training if the waiver is disapproved. The actual decision to approve or disapprove the waiver is not made until within 3 days of the training event, after current weather conditions are considered.

G3 is responsible for conducting an assessment of, and making a decision on, the training unit's request for waiver during Condition Red range conditions. The current OPLAN and FH Reg. 350-40 do not require consultation with the Natural Resources Management Branch on a decision to approve or disapprove a waiver request.

Assessments are focused on minimizing the loss of training time to III Corps units due to range fires, while protecting personnel, equipment, and endangered species habitat. G3 will then coordinate a G3/Directorate Plans Training Mobilization response to the requesting unit and update the Corps Operations Center daily as to which ranges have approved incendiary munitions waivers. If a waiver is approved, $G 3$ will place specific restrictions on the training unit commensurate with the range conditions. Type of appropriate restrictions (as coordinated between G3, the Fire Department and the Natural Resources Management Branch) include, but are not limited to:

a. No use of White Phosphons;

b. Units must have fire fighting equipment and fire detail on the range;

c. No firing directly into the Endangered Species Habitat Areas as designated by Burn Protection Zones in the Live Fire Area;

d. Unit must provide ACE or Bulldozer for certain Gunnery tables;

e. Mortar/artillery illunination rounds must achieve burnout at a minimum altitude before striking the ground; and

f. If fires continue and wind velocity increases above 20 knots, all firing must terminate.

\section{Endangered Species Management Plan}

The Reasonable and Prudent Measures (RPM \#5) and their associated Terms and Conditions (T\&C \#5) outlined in the 1993 Opinion include development of an ESMP. Army Regulation (AR) 200-3 also requires military installations to prepare an ESMP for all species listed or proposed as threatened and endangered. The objective of the Fort Hood ESMP is to provide natural resource managers and leaders of training operations with a comprehensive plan for maintaining and enhancing populations and habitats of the vireo and the warbler, while maintaining mission readiness in a manner consistent with Army and Federal environmental regulations. In addition to the warbler and vireo, the ESMP also addresses other listed species that have been observed on Fort Hood, including the whooping crane and bald eagle. One species of concern (Texabama croton), one recently delisted species that still requires monitoring (peregrine falcon), and several rare species (undescribed species of plethodontid salamander and undescribed species of cave invertebrates) are also included.

The ESMP provides descriptions of human activities on Fort Hood, including military activities (maneuver training, live-fire training, aviation training, and operational testing), training grounds (maneuver training areas, live-fire training areas, air operations, and explosives storage and handling), and non-military activities (juniper management, controlled/prescribed burning, grazing, and recreation). Development of the ESMP is based on the concept of adaptive management. An adaptive management approach recognizes that protection and management actions are often implemented with imperfect knowledge, and allows for the progressive development of monitoring and research approaches as better knowledge becomes available. This approach enhances decisionmaking and management capabilities. The ESMP is also based on the premise that protection, management, inventory, monitoring, and research are all necessary components of an integrated approach for threatened and endangered species on Fort Hood. Objectives, justifications, and actions are developed and implemented under a 
framework that is mutually supportive of these components. AR 200-3 provides the mechanism for incorporating new information and approaches by requiring annual reviews and major revisions of the ESMP every 5 years.

\section{Additional Measures to Minimize Cowbird Parasitism due to Cattle Grazing}

Cattle grazing is currently permitted on Fort Hood through a lease agreement with the Central Texas Cattlemen's Association (CTCA). The existing lease agreement ends March 31, 2001. The lease provides grazing opportunities on 80,940 ha (200,000 acres) of Fort Hood land, supporting a maximum of 3,500 animal units, and requires the lessee not to impact endangered species.

The 1993 Opinion identified brood parasitism by the cowbird as the most serious threat to the vireo and warbler from cattle grazing, and required research to determine the effects of cattle operations on parasitism (RPM \#3, $T \& C \# 3$ ). A radio-telemetry study examining the relationship between cattle grazing and the behavior of the cowbird was conducted in Training Areas 1.8 between 1994 and 1998 . The research demonstrated a positive relationship between the presence of cattle and the accurrence of cowbirds (The Nature Conservancy 1998). Fort Hood currently maintains an intensive cowbird trapping program in areas where cowbirds concentrate (near livestock feeding areas) throughout the installation.

The Natural Resource Conservation Service's (NRCS) "Fort Hood Vegetative Resource Inventory" (NRCS 1998) recommends a rotational grazing system that addresses training issues, but does not address endangered species issues. Likewise, the ESMP focuses on military training and endangered species issues, but does not address the effects of livestock grazing. Because endangered species management and grazing were not addressed simultaneously in one planning document, the Service met with representatives from Fort Hood, NRCS, Texas Parks and Wildlife Department (TPWD), U.S. Department of Agriculture Wildlife Services (WS), and CTCA on September 9, 1998 and October 15, 1998, to discuss options to resolve endangered species and grazing management issues on Fort Hood. The following two options were identified:

Option 1: For a 5-year period (beginning March 1, 1999), defer cattle from Grazing Management Units 6 and 7 (TAs 1-19) during the breeding season of the vireo and warbler (March 1 - August 31), by whatever means deemed necessary (i.e., continue exisung efforts to defer cattle from the cowbird snidy area). The stocking rate could be doubled during the non-breeding season (September 1 - February 28) so that the total number of animal unit years would remain about the same. Cowbird trapping and shooting would continue throughout the remainder of the installation. Cowbird trapping and shooting within Grazing Management Units 6 and 7 would resume if targeted parasitism levels (to be determined) are exceeded. This option would be reviewed at the end of the 5-year period.

Option 2: For a 5 -year period (beginning March 1, 1999), a cowbird trapping program would be implemented on private lands to minimize cowbird parasitism levels on Fort Hood.

Option 2 was proposed by CTCA and agreed to by the five cooperators through a signed and executed Memorandum of Understanding for this program on March 23, 1999 (USFWS 1998).

\section{Off Road Vehicle (ORV) Recreation}

The 1993 Biological Opinion (RPM \#4, T\&C \#4a) required Fort Hood to "eliminate the use of dirt bikes and other recreational ORVs in training areas which contain endangered species habitat at any time of the year (this will also eliminate any clearing for ORV trails in habitat)." On the basis of this requirement, ORV use was restricted to TA's 31-34, where no known habitat occurred. However, shortly after this designation a small colony of blackcapped vireos was discovered on Anderson Mountain in TA 33. Consequently, ORV use was further restricted to TA's 31, 32, and 34. The Fort Hood Dirt Riders Club built a motocross track in TA 34D. Sanctioned events, inchrding track races and trail rides and "upen riding", has taken place in these designated areas since 1993. 
Some evidence indicates that as Ashe juniper (Juniperus ashei) grows, thickens, and multiplies, it degrades the overall effectiveness of laser targeting equipment to the point of creating an unsuitable training environment. In the past, some training crews have had to push their gun system through the brush and expose themselves to enemy fire in order to "kill" enemy vehicles. Such situations teach crews improper battle techniques and degrade training. In real life, a 6-inch by 8 -foot juriper would not protect a vehicle from a $120 \mathrm{~mm}$ Sabot round. Additionally, prior to instituting a juniper clearing program, brush was so thick in some locations that units were visually restricted to "firing" upon enemy at distances of 2 kilometers $(\mathrm{km})$ or less. As a result, some training involving engagements over $2 \mathrm{~km}$ in distance were somewhat restricted. By managing juniper, Fort Hood is able to enhance training, making it as realistic as possible (Fort Hood memo 8/16/99 Response to Request for Supplemental Information for Amendment to the Biological Opinion).

In 1985, Fort Hood began an extensive program for the removal of juniper from maneuver training areas. The 1985 Natural Resource Management Plan called for brush cutting, to encourage hardwood regeneration, on approximately 3,840 ha for the period 1985 to 1990 . Of this, 2,225 ha were to be clear cut and 1,615 ha were to be hand cleared. Additionally, during the 1986 to 1989 period, a contract for juniper clearing on the west side of the reservation involved 8,700 ha. Areas selected were chosen primarily to increase available training space for the military. Areas where pure stands of juniper were present received top priority for cutting. Other areas cut were preferred training sites that had become too thick for training due to juniper encroachment (Fort Hood memo 8/16/99 Response to Request for Supplemental Information for Amendment to the Biological Opinion).

However, in May 1990, juniper clearing was suspended on Fort Hood after informal consultation between Fort Hood and the Service regarding the addition of the golden-cheeked warbler to the endangered species list. Since juniper is an essential component of the habitat for this endangered species, it was determined that juniper clearing could have a negative impact. The 1993 Opinion required Fort Hood to "eliminate juniper cutting in endangered species habitat, except in accordance with supervised actions outside of the nesting season and the approved vireo management plan."

In 1995, Fort Hood in consultation with the NRCS, entered into negotiations to start clearing juniper from Fort Hood training lands. Not all juniper is removed, and the juniper needed for endangered species management is not cleared. The goal of the original program was to clear 21,044 ha of training land to enhance reatistic training, sustain current training land capabilities, create more open areas for long range shot training, and enhance the use of the Army's primary non-live fire training system (Fort Hood memo 8/16/99 Response to Request for Supplemental Infornation for Amendment to the Biological Opinion).

\section{Project Description}

\section{Endangered Species Management Plan}

The ESMP will be reviewed annually and updated as required every 5 years to meet conservation goals and Army mission requirements. In particular, updated information about population viability analysis models, distribution of endangered and threatened species, new research projects, habitat changes, and land use changes should be incorporated into the revisions. This ESMP will be incorporated by inclusion or by reference into the Fort Hood Integrated Natural Resource Management Plan (TNRMP), once approved by the installation commander. Once every five years the INRMP, including the ESMP section, must undergo a major revision to all parts (AR 200-3, paragraph 9-4). If modifications are made to the ESMP, formal consultation must be reinitiated. The implementation schedule for tasks and objectives in the ESMP is subject to the availability of funds.

For both the vireo and the warbler, the primary objective of the ESMP is to minimize any loss of habitat on Fort Hood due to fire, training, or other habitat altering activities. However, since some habitat loss is inevitable, the ESMP has designated "core" and "non-core" habitats. "Core" habitats are those areas on Fort Hood that are cssential for population viability, and thus are intensively managed to promote the long-term survival and recovery of the species. Training restrictions in core habitats are conducted in accordance with the Fort Hood Endangered 
Species Training Guidelines, included in Appendix C of the ESMP. "Non-core" habitats are those areas where training restrictions are lifted in exchange for the intensive management and protective efforts in core habitat.

The Natural Resources Management Branch will maintain and update digital layers depicting the distribution of core and non-core habitat on the installation. Revised Training Area maps will be issued or available to all applicable installation commands and training suppont elements. All reasonable efforts will be made to collect and destroy all earlier editions.

The map overlay for all endangered species habitats (core and non-core) within the Live-fire Training Areas (TAs 61-94) will be labeled as "Bum Protection Areas". No maneuver training is conducted within the Live-fire Training Areas, so most training restrictions are not relevant in those TA's, with the exception of those related to use of incendiary devices and Fort Hood's fire management and protection policies. "Burn Protection Area" labeling focuses installation attention on the impartance of implementing fire prevention and mitigation policies in these areas. Training Area maps will be revised every 5 years concurrent with the 5 -year revision of this ESMP to incorporate any changes in designated habitats subject to training restrictions.

Of the estimated 21,496 ha of warbler habitat on Fort Hood, 14,879 ha have been designated as core habitat (Figure 8 in the ESMP). Of the total 5,319 ha estimated to be vireo habitat $(2,649$ ha of existing habitat plus an additional 2,670 ha that will become suitable for occupation during the 5-year term of this ESMP), 4,184 ha is designated as core habitat (Figure 8 in the ESMP). Rationale for the core/non-core habitat designations and corresponding measures to minimize habitat loss are provided in Chapters 6 and 7 of the ESMP.

The ESMP and this revised Opinion do not address habitat loss from any planned land use activities on Fort Hood that would preclude long-term natural regeneration of habitat (i.e. permanent takings). Examples of such activities that would not be covered include facility construction, clearing for firing ranges, and clearing for intensive mechanized vehicle maneuvers. These types of actions in either core or non-core habitat would require Fort Hood to initiate a separate section 7 consultation with the Service prior to implementation. The only loss of core habitat that does not require consultation is loss due to uncontrolled burns.

Brown-headed cowbird control efforts will be maintained and enhanced in proximity to vireo and warbler habitats (both core and non-core) to enhance productivity. Trap effort will continue to be conducted at levels sufficient to maintain parasitism levels of vireo nests below an average of $10 \%$ annually, in non-live-fire training areas, during the 5-year term of the ESMP. Female cowbirds will continue to be removed during the peak vireo and warbler breeding months (March-June). Shooting will continue within selected occupied habitats where high levels of cowbird parasitism have been documented, despite trapping effort. Cowbird trapping during the months of July through February will continue to be conducted to reduce resident adult cowbird populations, reduce juvenile female abundance, reduce vandalism damage, and provide year-round presence and awareness among troops training in the field. With the completion of cattle/cowbird studies (The Nature Conservancy 2000) in the northeast training ranges, cowbird control activities including trapping and shooting will be enhanced in the northeast training ranges (TAs 1-19).

Consultation with the Service will be initiated if the five-year average of $10 \%$ annual parasitism is exceeded. The intent of this objective is to maintain an average annual parasitism rate below $10 \%$ over the five-year term of the ESMP, i.e. a rate greater than $10 \%$ in any one year would not necessarily trigger consultation unless the annual rate precluded achieving a five-year average of less than $10 \%$. This, in effect, calculates a rolling average determined annually during the five-year term of the ESMP by adding the annuai parasitism rate for all years up to the current implementation year and dividing by five. If the result is an average parasitism rate greater than $10 \%$, the installation will initiate consultation with the Service. Annual parasitism rates and the calculation of the fiveyear average parasitism rate will be reported annually to the Service as part of the annual reporting requirement. The formula for calculating the rolling average can be found in Chapter 7 of the ESMP.

In the vicinity of caves and karst features where military training increases the risk of vegetation destruction and sedituestlation, buffer zones will be implemented by placing signs or other barriers at sufficient distance from cave 
entrances to minimize disturbance. Changes in representative samples of endemic cave fauna and species listed, or proposed for listing, in the future will be monitored as outlined in Chapter 9 of the ESMP.

\section{Memorandum of Understanding (MOU) - Cowbird Trapping on Private Lands Surrounding Fort Hood}

The March 23, 1999 MOU between the Service, Fort Hood, TPWD, WS, and CTCA defines the roles and responsibilities of each cooperator in implementing a brown-headed cowbird trapping program on private lands to minimize cowbird parasitism on the vireo and warbler on Fort Hood. CTCA is responsible for maintaining at least 27 fully operational cowbird traps from March 1 through May 31 of each year (under contract with WS) in areas designated by the Natural Resources Management Branch. The Service, Fort Hood, and TPWD are primarily responsible for providing technical assistance.

The goal of the private lands trapping program is to maintain cowbird parasitism levels in core habitat areas on Fort Hood at less than $10 \%$ per season. If this goal is not met, all cooperators will reconvene within 60 days following written notification from Fort Hood to identify possible causes and solutions, and amend the MOU accordingly.

The MOU will remain in force until March 23, 2004. The 27 cowbird traps must be fully operational and maintained as specified in the MOU or the MOU will be terminated. Should the MOU be terminated, CTCA will remove all cattle from Grazing Maragement Units 6 and 7 (TAs 1-19) during the breeding season of the vireo and warbler (March 1 - August 15). If modifications are made to the existing MOU, formal consultation with the Service would be reinitiated and the Opinion amended accordingly.

\section{Off Road Vehicle Recreation}

Recent efforts to ground truth all woodland habitat on Fort Hood to evaluate suitability potential for endangered species have produced 22 observations of black-capped vireos and 3 observations of golden-cheeked warblers in designated ORV areas over the past 3 years. No long-term survey/census data for these training areas exists; however, it is believed that usage of these areas has occurred recently, whether due to creation of suitable habitat, expansion of bird populations, or some other reason. In 1999, an inspection of TA 34 revealed damage to archeological/cultural sites by ORV use, which resulted in restriction, for an indefinite period, of all ORV use to a 50-acre site within sub-area 34D, where the constructed track is located. Habitat patches where birds have been observed, or where vegetation structure and composition suggest suitability for endangered species have been identified and mapped in all training areas currently designated for ORVs. Acreages for these habitat patches are included in totals used in the ESMP.

\section{Juniper Management}

As of January 10,2000, mechanical clearing of juniper has been completed. The Natural Resources Management Branch has issued guidance to the ITAM Juniper Clearing Program that the requested non-ground disturbance clearing of juniper from riparian zones will be strictly limited to a case by case, mission-essential requirement only (J. Cornelius, pers. com., 2000).

A GIS coordination map delineating the areas proposed to be cleared is sent from G3 to the Directorate of Public Works, which locates natural and cultural resource areas that are to be restricted from juniper removal (Fort Hood G3 Juniper Management Program slides 8/99). All control efforts and contracts are coordinated through the Natural Resources Management Branch to avoid impacts on the vireo and the warbler under this Opinion and the ESMP. Control efforts are not allowed within a $100 \mathrm{~m}$ buffer around core and non-core endangered species habitats.

However, "experimental" use of a shear to perform surgical removal of encroaching juniper from black-capped vireo habitat in areas where habitat structure is maintained by military training impacts, may be a useful tool for maintaining vireo habitat. Current juniper control methods include prescribed burns, cutting and bulldozing. 


\section{Listed Species Affected}

\section{Black-capped Vireo}

Since the 1993 Opinion, research and conservation efforts on Fort Hood have included continual inventory and monitoring, studies of nest depredation and assessment of training activities, habitat restoration, study of researcher activities on nesting vireos, nest site/habitat analysis, assessment of cowbird movements and activity, and a cowbird control program. Current efforts are discussed in Chapter 7 of the ESMP and the Reasonable and Prudent Measures (RPM \# 8 and T\&C \# 8b) section of this Amendment.

Figure 4 of the ESMP shows the distribution of known vireo habitat based on visual interpretation of aerial photography and ground surveys. Vireos are known to exist elsewhere on the installation, but these are typically isolated territories within warbler habitat. The current estimate of available habitat on Fort Hood is 2,649 ha. An additional 2,670 ha of habitat should become suitable for occupation during the 5-year term of the ESMP. Thus, a total of 5,319 ha of habitat will become suitable for occupation within five years.

The 1995 Population and Habitat Viability Analysis Workshop Report (USFWS 1996a) indicates that habitat carrying capacity lower than that necessary to support 1,000 singing vireo males greatly increases the risk of extinction. Thus, the ESMP has identified this carrying capacity as a goal, with additional research to refine the population viability models. Current population viability analysis (PVA) and observed densities of adult males on Fort Hood indicate a minimum of 4,170 ha of vireo habitat is necessary to achieve a carrying capacity of 1,000 singing males. The ESMP designates 4,184 ha to be managed as core habitat for the vireo. Primary threats to vireo survival documented at Fort Hood include brood parasitism, habitat loss and degradation, and fire suppression. Additional information on the vireo (including migration, habitat, food resources, population estimates, survival and dispersal, reproductive biology, interactions with other species, and threats), both rangewide and on Fort Hood, is summarized in the ESMP.

\section{Golden-cheeked Warbler}

Monitoring and research activities for the warbler on Fort Hood were first initiated in 1991. These conservation efforts include point count surveys to determine population trends, demographic and reproductive monitoring in selected study sites, research in habitat selection, studies to determine the effects of habitat fragmentation and wildfire on warbler demographics, and population viability analyses. Current efforts are discussed in Chapter 6 of the ESMP and the Reasonable and Prudent Measures (RPM\# 8 and T\&C \# 8a) section of this Amendment.

Figure 4 of the ESMP shows the distribution of potential warbler habitat based on visual interpretation of aerial photography and ground surveys. The current estimate of available habitat is 21,496 ha.

The 1995 Population and Viability Assessment report (USFWS 1996b) indicates that habitat carrying capacity lower than that necessary to support a maximum of 1,000 singing warbler males greatly increases the risk of extinction. In part because of the long-term impacts of the habitat lost in the 1996 fires, the ESMP identifies a carrying capacity goal of 2,000 singing males. Current PVA and observed densities of adult males on Fort Hood indicate an estimated minimum of 8,520 ha of warbler habitat is necessary to achieve a carrying capacity of 2,000 singing males.

Range wide threats to the warbler include breeding habitat loss, loss of winter and migration habitat, habitat fragmentation, nest parasitism by cowbirds, destruction of oaks (USFWS 1992), reservoir development, oak wilt, predation, and secondary effects of urbanization in proximity to warbler habitats (USFWS 1996b). Fire ants are a documented predator on the black-capped vireo as well as the golden-cheeked warbler (J. Cornelius, pers. com., 1999). 
Incidence of oak wilt fungus has been observed on Fon Hood. Although oak wilt is currently not thought to be a significant problem, its potential spread warrants further monitoring. Additional information on the warbler (including migration, habitat, food resources, population estimates, survival and dispersal, reproductive biology, interactions with other species, and threats), both range-wide and on Fort Hood, is summarized in the ESMP.

Fort Hood has the largest known populations of bath the golden-cheeked warbler and the black-capped vireo under one management authority. The data collected and analyzed at Fort Hood represents some of the most comprehensive work done on both species in their respective ranges.

\section{Bald Eagle}

The bald eagle (Haliaeetus leucocephalus) has been recorded during winters at Belton Lake on or adjacent to Fort Hood, but does not nest on the installation (J. Cornelius, pers. com., 1999). The Service has recently proposed the bald eagle for delisting in the July 6,1999 Federal Register. A final decision is expected in July 2000 . In the event that the bald eagle is delisted, the Bald Eagle Protection Act of 1940 and the Migratory Bird Treat Act (MBTA), if applicable to federal entities, would provide continued protection. Additionally, the Endangered Species Act would continue to require monitoring of the delisted species for a period of 5 years.

\section{Whooping Crane}

The whooping crane (Grus americana) is a rare migrant. Five whooping cranes were sighted in Training Area 15 during December 1986. They may fly over or near Fort Hood during spring (April $1-20$ ) and fall (October $1-20$ ) migration and may stop at Belton Lake (Hayden 톼 all. 1998).

\section{Species of Concern and Other Rare Species}

\section{Peregrine Falcon}

Anecdotal observations of peregrine falcons (Falco peregrinus) have been recorded on Fort Hood. Peregrine falcons do not nest on the installation and any observations are likely transitory migrants. The peregrine falcon has recently been delisted from the Act, with the publication of a final rule in the August 25, 1999 Federal Register. However, monitoring the status of the peregrine falcon for a period of 5 years is required under the Act, and this species is still protected under the MBTA outside of the installation, per the Federal exemption under the MBTA.

Fort Hood is continuing to monitor peregrine falcon activity while present on the installation and assessing the potential for disturbance from human activity. The Natural Resources Management Branch would notify G3, Range Control and other appropriate training and operations organizational elements of any potential training disturbance in proximity to observed individuals.

\section{Texabama croton}

The Texabama croton is a species of concern that was formerly a Service category 2 candidate for Federal listing. Additional information on this species is summarized in the 1993 Opinion and Chapter 8 of the ESMP.

Fort Hood is continuing to monitor the status and distribution of populations and visiting known locations annually to visually assess condition of known populations. Known locations are protected from human-related disturbance. 
Several endemic and currently undescribed cave invertebrate species and one undescribed species of salamander (Plethodon sp.) occur on Fort Hood. Rare or endemic species known to occur on Fort Hood are listed in Table 3 of the ESMP. A report is currently in preparation summarizing the location and structure of each cave and karst feature known on Fort Hood, and taxonomic status of biological collections. Specimens of the probable new salamander species have been collected from caves in the northeast training ranges of Fort Hood and are currently undergoing taxonomic review to determine species status. A full description and discussion of the potential threats to these cave fauna can be found in Chapter 9 of the ESMP. The status of biological collections in surveyed (interior dimensions mapped) and unsurveyed (interior dimensions not mapped) caves on Fort Hood can be found in Tables 4 and 5, respectively, of the ESMP.

Fort Hood is continuing to protect sensitive cave and karst features from human-related risk factors identified in the Endangered Karst Invertebrates Recovery Plan (USFWS 1994). All current cave gates are inspected annually and maintenance performed as needed, and additional gates will be constructed at other cave/karst feature entrances if appropriate. Within the next 5 years, Fort Hood will develop a Karst Management Plan which provides for regular monitoring of endemic cave-obligate fauna populations, monitoring and control of imported fire ants which threaten cave fauna, and long-term recommendations for management of karst resources.

\section{DMPACTS OF THE ACTION}

\section{Direct Impacts}

Direct impacts to the vireo and warbler from military, grazing, and recreation activities are similar to those described in the 1993 Opinion. However, the total amount of direct impacts from military activities is expected to increase in non-core habitats with the lifting of training restrictions in exchange for increased protection and management of core habitats. This revised Biological Opinion incorporates activities associated with the ESMP, impacts from the February 1996 fires, additional measures to minimize cowbird parasitism on golden-cheeked warbler and black-capped vireo populations due to grazing programs on Fort Hood, off-road vehicle recreation in or near endangered species habitat, and juniper management.

Since the juniper management program is essentially complete, and any future juniper clearing must be coordinated with the Natural Resources Management Branch with a $100 \mathrm{~m}$ buffer delineated around endangered species habitat, no direct impacts to the vireo or warbler are anticipated.

Other than the impacts from grazing discussed in the 1993 Opinion, no direct impacts to the vireo or warbler from the cowbird control program are anticipated.

\section{Black-capped Vireo}

The ESMP minimizes the direct impacts from the February 1996 fires by implementing measures (updating and revising fire management and control policies) to prevent the future occurrence of similar fires, conducting research to evaluate the effects of the fires on the vireo, designating core habitat that is managed for the vireo, and converting all 2,670 ha of habitat lost during the fire to vireo habitat.

In addition to the impacts from the February 1996 fires, the Service anticipates that up to 230 ha of habitat loss would be allowed to occur during the 5-year term of the ESMP due to training activities in non-core habitat and/or uncontrolled fire in either core or non-core habitat.

The following table (Table 2 in the ESMP) summarizes the anticipated level of impacts to the vireo that would occur during the 5-year term of the ESMP and required actions to minimize the habitat loss: 


\begin{tabular}{|l|l|}
\hline $\begin{array}{l}\text { Habitat loss } \\
\text { (ba) }\end{array}$ & Action Required \\
\hline $0-230$ & $\begin{array}{l}\text { No action required for loss due to training activities in areas not subject to } \\
\text { the Fort Hood Endangered Species Training Guidelines (i.e. non-core } \\
\text { habitat) and loss due to accidental fire (training related and prescribed burn } \\
\text { treatments) in all habitat areas. Report incidental take levels annually to } \\
\text { the Service as part of regular reporting requirement. }\end{array}$ \\
$\begin{array}{l}\text { Loss due to proposed construction activities or other activities that } \\
\text { permanently alter babitat (in either core or non-core habitat) requires } \\
\text { separate section } 7 \text { consultation. }\end{array}$ \\
$\begin{array}{l}\text { Loss due to training activities in areas subject to the Fort Hood Endangered } \\
\text { Species Training Guidelines (i.e. core habitat) requires section } 7 \\
\text { consultation. }\end{array}$ \\
\hline$>230$ & $\begin{array}{l}\text { Incidental take under the Incidental Take Statement and Fort Hood's ESMP } \\
\text { exceeded. Requires section } 7 \text { consultation with the Service. }\end{array}$ \\
\hline
\end{tabular}

Due to the extensive amount of burned vireo ( $415 \mathrm{ha})$ and warbler $(2,313 \mathrm{ha})$ habitat in very early seral stage $(<3$ years) on Fort Hood, habitat manipulation is not essential during this first 5 -year term of the ESMP to achieve population carrying capacity objectives for vireos. Fort Hood maintains several intensive vireo study areas that may require habitat manipulation to maintain current habitat conditions in order to ensure the continuity of data obtained from these areas. Therefore, any habitat restoration activities in these intensive study areas will not be included in the incidental take levels. In addition, a future requirement to maintain the current 5,319 ha of habitat in an early seral stage of 1 to 20 years requiring land managers at Fort Hood to implement habitat restoration activities will be addressed in the subsequent revisions of the ESMP and associated biological opinion. The Natural Resources Management Branch will maintain an official file on all activities addressed in the ESMP that result in habitat loss and report these activities to the Service as part of the annual reporting requirement required under this amendment.

Loss of core habitat due to any activity other than uncontrolled burns is not authorized in this amendment. Thers activities would require Fort Hood to initiate a separate section 7 consultation with the Service prior to implementation.

\section{Golden-cheeked Warbler}

The ESMP minimizes the impacts from the February 1996 fires by implementing measures (updating and revising fire management and control policies) to prevent the future occurrence of similar fires, conducting research to evaluate the effects of the fires on the warbler, and designating 14,879 ha of habitat to be protected and managed as core habitat for the warbler. The ESMP designates 14,879 ha to be managed as core habitat for the warbler. Habitat designated as "core" in excess of the 8,250 ha carrying capacity objective provides pre-mitigation for habitat loss exceeding the incidental take limit (refer to the ESMP for a full, step-by-step explanation).

In addition to the impacts from the February 1996 fires, the Service anticipates that up to 519 ha of habitat loss would occur during the 5-year term of the ESMP due to training activities in unrestricted habitat and/or uncontrolled fire in either protected or unrestricted habitat.

The following table (Table 2 in the ESMP) summarizes the anticipated level of impacts to the warbler that would occur during the 5-year term of the ESMP and required actions to minimize the habitat loss: 


\begin{tabular}{|l|l|}
\hline $\begin{array}{l}\text { Habitat loss } \\
\text { (ha) }\end{array}$ & Action Required \\
\hline $0-519$ & $\begin{array}{l}\text { No action required for loss due to training activities in habitats not subject } \\
\text { to the Fort Hood Endangered Species Training Guidelines (i.e. non-core } \\
\text { habitat) and loss due to accidental fire (training related and prescribed burn } \\
\text { treatments) in all habitat areas. Report incidental take annually to the } \\
\text { Service as part of regular reporting requirement. }\end{array}$ \\
$\begin{array}{l}\text { Loss due to proposed construction activities or other activities that } \\
\text { permanently alter habitat (in either core or non-core habitat) requires } \\
\text { section 7 consultation. }\end{array}$ \\
$\begin{array}{l}\text { Loss due to training activities in areas subject to the Fort Hood Endangered } \\
\text { Species Training Guidelines (i.e. core habitat) requires section 7 } \\
\text { consultation. }\end{array}$ \\
\hline$>519$ & $\begin{array}{l}\text { Incidental take under the Incidental Take Statement and Fort Hood's ESMP } \\
\text { exceeded. Requires section 7 consultation with the Service. }\end{array}$ \\
\hline
\end{tabular}

Loss of core habitat due to any activity other than uncontrolled burns is not authorized in this amendment. These activities would require Fort Hood to initiate a separate section 7 consultation with the Service prior to implementation.

\section{Other Listed Species}

Based on the protective measures identified in the ESMP, no direct impacts to the bald eagle or whooping crane are anticipated from military activities, fire, cattle grazing, off-road vehicle recreation, or juniper management.

\section{Indirect Impacts}

Indirect impacts from military and grazing activities are discussed in the 1993 Opinion. Indirect impacts from the juniper management program on the vireo and the warbler may include the spread of oak wilt, spread of fire ants, and increased fire hazard due to the piling of cleared brush.

The Natural Resources Management Branch will continue to monitor cowbird parasitism levels to ensure the effectiveness of the cowbird control program on private lands. If cowbird parasitism levels in core habitat areas exceed the goal of $10 \%$ per season, all cooperators will reconvene within 60 days following written notification from Fort Hood to identify possible causes and solutions and amend the MOU accordingly. Modifications to the MOU would require reinitiation of formal consultation and an amendment to this Opinion.

\section{Black-capped Vireo}

Indirect impacts from the loss of 421 ha of vireo habitat during the 1996 fires includes displacement of vireos that occupied these areas, and temporary crowding and increased competition in the remaining habitat. However, this impact is short-term since vireos are expected to occupy the burned areas within the 5-year term of the ESMP. Vireos were observed nesting in portions of the burned areas during the 1998 nesting season and are continuing to expand into these areas. Fort Hood is monitoring the successional development of vireo habitat and vireo colonization after the tire. 


\section{Golden-cheeked Warbler}

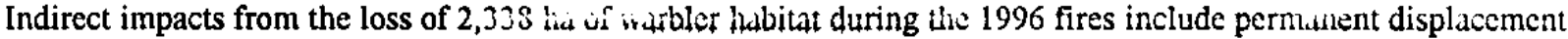
of the warblers that occupied these areas, and crowding and increased competition in the remaining habitat. Because of the time required to regenerate warbler habitat, these indirect impacts are long-term. Fort Hood is studying the dispersal patterns of warblers displaced from the burned areas, and warbler use of isolated patches and fragmented habitat within and peripheral to the fire area.

\section{Other Listed Species}

Based on the protective measures identified in the ESMP, no indirect impacts to the bald eagle or whooping crane are anticipated from military activities, fire, cattle grazing, ORV recreation, or juniper management.

\section{Cumulative Effects}

Cumulative effects include the effects of future State, tribal, local or private actions that are reasonably certain to occur in the action area considered in this biological opinion. Future Federal actions that are unrelated to the proposed action are not considered in this section because they require separate consultation pursuant to section 7 of the Act.

\section{Urbanization}

The populations of Bell and Coryell Counties at present are predominately rural outside of the small cities of Temple, Belton, and Killeen. Urbanization tends to occur along interstate highway systems, particularly around major urban centers and around lakes or woodland habitats with recreational opportunities. Current trends toward decentralization of work centers is expected to increase, freeing people to locate further from urban core areas.

The expected population growth of Bell County is projected from a 1995-population of 213,333 to as high as 445,061 by 2030. The expected population growth of Coryell County is projected from a 1995-population of 73,205 to as high as 159,810 by 2030 (TSDC 1998). This trend will lead to increased urbanization in these counties. The result will be additional residential and industrial development that may eliminate habitat of the golden-cheeked warbler and black-capped vireo.

\section{Agricultural Activities}

Livestock and hay production activities are expected to cause continuation of a current trend to clear post oak woodlands and convert them to bermuda grass pastures. The drought in Texas has depressed cattle markets and herd sizes temporarily, but a recovery is expected in the next few years, putting increased pressures on range and pasturelands. The drought has increased the demand for hay statewide and associated increases in prices for hay has increased the demand for more high-yielding pastures. Consequently, market conditions currently support the conversion of additional woodland to hayfields, as well as the increased use of herbicides and seeding with exotic species. All of these practices aggravate habitat fragmentation.

With an increase in livestock production, a corresponding increase in the potential for brown-headed cowbird parasitism on both Federally listed, especially the black-capped vireo, and non-listed songbirds also exists. Efforts to expand cowbird trapping efforts on private lands in priority recovery areas for the vireo are ongoing.

\section{BIOLOGICAL OPINION}


Based on the preceding information, it is the Service's biological opinion that military and associated activities on Fort Hood Military Reservation are not likely to jeopardize the continued existence of the black-capped vireo, golden-cheeked warbler, bald eagle or whooping crane.

\section{INCDENTAL TAKE}

Section 9 of the Act prohibits any taking of listed species without a special permit or exemption. The term "take" in the context of the Act means to "harass, harm, pursue, hunt, shoot, wound, kill, trap, capture, or collect, or to attempt to engage in any such conduct". Furthermore, the term "harass" in the definition of "take" means an intentional or negligent act or omission that creates the likelihood of injury to wildlife by annoying it to such an extent as to significantly disrupt normal behavioral patterns (behavioral patterns include, but are not limited to, breeding, feeding, and sheltering). An example of an act that may harass a protected species is conducting activities in the midst of an actively breeding vireo population. The noise and passage of people and/or vehicles through such an area could disrupt breeding behavior or other essential behaviors, thus resulting in "take".

The term "harm" in the definition of "take" means an act that actually kills or injures wildlife. Such acts may include significant habitat modification, degradation, or destruction where it actually kills or injures wildlife by significantly impairing essential behavioral patterns (including, but not limited to, breeding, feeding, or sheltering). An example of an act that would harm a protected species is habitat destruction in an area used by an endangered species, if it renders the area unsuitable for breeding or other essential behaviors, even if undertaken while individuals of the species are temporarily not in the area (migratory species that winter elsewhere). Incidental take refers to takings that result from, but are not the purpose of, carrying out an otherwise lawful activity.

Under terms of sections $7(b)(4)$ and 7 (o)(2) of the Act, taking that is incidental to, and not intended as part of the agency action, is not considered a prohibited taking, provided that such taking is in compliance with the incidental take statement in a biological opinion. In that regard, the reasonable and pnudent measures and associated terms and conditions described below are non-discretionary and must be followed by the Department of the Army, Fort Hood Military Reservation.

\section{The Service is amending the incidental take statement in the 1993 Opinion as follows:}

The Service anticipates 230 ha of vireo habitat will be impacted by military activities in non-core habitat and uncontrolled fires in core and/or non-core habitat during the 5 year term of the ESMP. This incidental take limit is based on a renewable 5 year cycle of vireo habitat regeneration and is consistent with long-term habitat requirements needed to meet carrying capacity objectives for vireo habitat on Fort Hood. The ESMP initially designates 4,184 ha of vireo habitat as core habitat. If vireo habitat loss exceeds 230 ha at any time during the 5 year term of the ESMP, Fort Hood must initiate consultation with the Service. Core habitat will be increased at a 4:1 ratio for any habitat loss in excess of 230 ha during the five year term of the ESMP. Fort Hood will report incidental take to the Service on an annual basis.

The Service anticipates 519 ha of warbler habitat will be impacted by military activities in non-core habitat and uncontrolled fires in core and/or non-core habitat during the 5 year term of the ESMP. This incidental take limit is based on a renewable 25-year cycle of warbler habitat regeneration and is consistent with long-term habitat requirements needed to meet carrying capacity objectives for warbler habitat on Fort Hood. The ESMP initially designates 14,879 ha of warbler habitat as core habitat. If warbler habitat loss exceeds 519 ha at any time during the five year term of the ESMP, Fort Hood must initiate consultation with the Service. Core habitat will be increased at a 4:1 ratio for any habitat loss in excess of 519 ha during the 5 year term of the ESMP. Fort Hood will report incidental take to the Service on an annual basis.

The incidental take limits for vireos and warblers do not apply to habitat loss from any planned land use activities on Fort Hood that would preclude long-term natural regeneration of habitat (i.e. permanent takings). Examples of 
such activities that would not be covered under this incidental take include facility construction, clearing for firing ranges, and clearing for intensive mechanized vehicle maneuvers. Incidental take for these activities will require Fort Hood to initiate consultation with the Service prior to implementation.

The 4:1 mitigation ratio shall remain in place until such a time as the Service and Fort Hood deem it appropriate to change. Fort Hood, in consultation with the Service, may propose a lower mitigation ratio if the installation can provide documentation that habitats receiving increased protected status are of equal or better quality that habitat areas that were lost. Changing the mitigation ratio (increasing or decreasing) will require reinitiation of consultation between the Service and Fort Hood, as a change in the mitigation ratio impacts the amount of authorized incidental take.

The incidental take statement provided in this biological opinion satisfies the requirements of the Act. This statement does not constitute an authorization for take of migratory birds under the Migratory Bird Treaty Act, the Bald Eagle Protection Act, or any other Federal statute.

\section{REASONABLE AND FRUDENT MEASURES}

In addition to the reasonable and prudent measures identified in the 1993 Opinion, the Service believes the following reasonable and prudent measures are necessary to minimize take and any possible significant effects to the vireo and the warbler, as well as other listed species:

1) Monitor the distribution and spread of aak wilt, and use appropriate measures to limit effects on endangered species habitat.

2) Manage vegetation clearing projects to minimize fire hazard from slash and avoid impacts to residual stands.

3) Emphasize the use of prescribed burning to support protection and maintenance of endangered species habitat, and support ecosystem management principles.

4) Evaluate the effects of predation on endangered species productivity, and investigate management options to reduce nest losses.

5) Monitor the quality and quantity of available endangered species habitat.

6) Incorporate preventative measures to avoid future uncontrolled burns similar to the February 1996 fires.

7) Implement training restrictions in core habitat.

8) In addition to habitat protection and management, implement monitoring and research programs for the golden-cheeked warbler and black-capped vireo.

9) Institute protective measures for the bald eagle and whooping crane and other species of concern.

10) Restrict recreational use in endangered species habitat.

\section{TERMS AND CONDITIONS}

To be exempt from the taking prohibition of section 9 of the Act, the Department of Defense, U.S. Department of the Army, Fort Hood is responsible for compliance with the following terms and conditions, which implement the reasonable and prudent measures described above. 
1) Monitor the distribution and enead of oak wilt, and use appropriate measures to limit effects on endangered species habitat.

a) Develop and maintain a current map of oak wilt centers, with particular emphasis on training areas where core endangered species habitat accurs.

b) Identify and prioritize oak wilt centers which threaten, or may potentially threaten, core habitat.

c) Investigate treatment and/or isolation methods which might be feasible to limit oak wilt effects.

d) Implement appropriate measures based on priority evaluation.

e) If fungal mats are identified on trees that necessitate removal of that tree during the breeding season, a representative of the Natural Resource Management Branch will be present to ensure that the tree is not being directly utilized by the golden-cheeked warbler as a nesting site. Every effort will be taken to avoid or minimize a direct impact to listed species as a result of management for oak wilt. Such activities will be included under the incidental take levels outlined in this Biological Opinion.

2) Manage vegetation clearing projects to minimize fire hazard from slash, and avoid impacts to residual stands.

a) During juniper clearing or other brush removal projects, construction of firebreaks, power line right of ways, roads, etc., avoid piling material around or against residual standing trees. Ensure that slash material is pulled away from standing live trees and removed from the site, burned, or mulehed in place. Slash disposal methods will be included in the scope of proposed projects.

b) Where possible, mulching slash material on site is preferable to removal or burning, in order to return nutrients to the soil and reduce erosion.

c) As an integral part of project design, maximize the use of preventative measures to minimize soil loss after vegetation removal. Examples include re-seeding with native herbaceous plant seed, deferral of grazing from rehabilitation sites, placement of water bars on slopes, and using waste material in gullies as appropriate.

d) All vegetation clearing projects must include coordination with Natural Resources Management Branch from the planning phase forward in order to minimize or avoid impacts to endangered species and their habitat, and must support overall objectives of the INRMP, of which the ESMP is a part.

e) In the next five years, develop a habitat regeneration/enhancement plan that is compatible with endangered species management and mission training requirements.

3) Emphasize the use of prescribed burning to support protection and maintenance of endangered species habitat, and support ecosystem management principles.

a) All prescribed burning must be overseen by Natural Resources Management Branch personnel certified and experienced in prescribed burning techniques, and support the overall objectives of the INRMP.

b) In cooperation with the Kerr Wildlife Management Area, investigate the use of prescribed fire for maintenance of habitat suitability for black-capped vireos. Incorporate the use of maintenance burns as a tool where feasible.

c) Inside the Live-Fire Area, and in other locations where the risk of training fires is high, use prescribed fire to the maximum extent possible to reduce fuel loads near important areas.

d) If a rotational grazing management plan is implemented, use prescribed fire in deferred grazing areas to maintain prairie sites and to inhibit development of pure juniper stands. Fire should be considered as a low-cost, non-invasive means of avoiding future need for destructive large-scale mechanical clearing projects.

4) Evaluate the effects of predation on endangered species productivity, and investigate management options to reduce nest losses.

a) Investigate species-selective methods for control of imported fire ants in endangered species habitat and near important karst features.

b) If coyote control is considered, video monitoring should be considered as a way to determine if the removal of coyotes in nesting habitat has an impact on the rate of nest predation by other species. Fortwide coyote control should not be instituted until any potential negative impacts to endangered species has been addressed. 
5) Monitor the quality and quantity of available endangered species habitat.

a) Quarterly helicopter over-flights should be taken to ensure compliance with guidelines in the ESMP and this revised Opinion.

b) Evaluate habitat trends based on change detection imagery every 5 years.

c) Maintain adequate natural resource law enforcement presence to effectively monitor land use, and enforce training guidelines and off-road vehicle restrictions.

6) Incorporate preventative measures to avoid future uncontrolled burns similar to the February 1996 fires.

a) Increase fire prevention and response efforts by:

(i) coordinate with the Fire Department and Natural Resource Management Branch during the decision to approve/disapprove Range Condition Red waivers;

(ii) develop a 5-year plan to build and/or upgrade fire access roads and firebreaks, and;

(iii) maintain and upgrade fire-fighting capabilities, subject to the availability of funds.

b) Initiate research on the effects of the burn and additional studies to benefit the vireo and warbler.

c) Refine mapping efforts to enhance endangered species information management on Fort Hood.

7) Implement training restrictions in core habitat.

a) Training restrictions should be implemented at two levels (Appendix $C$ of the ESMP). Level 1 applies from September 1 through February 28. Level 2 is more restrictive, and applies from March 1 through August 31 .

i) Level 1 restrictions:

A) Report all fires to Range Control. Do not start fires.

B) Use previously established firing points, fighting positions, and emplacements only.

All digging must be cleared through the Directorate of Public Works, Natural Resource Management Branch.

C) Comply with range rules regarding use of flares, incendiary munitions, etc. Ensure that firefighting equipment and personnel on hand are in compliance with Fire Danger Rating Standard Operating Procedures.

D) Park equipment in open areas only. Do not cut brush or trees for camouflage, road blocks, or other purposes.

E) Use existing roads and trails. Do not drive vehicles through or over woody vegetation.

F) Do not tamper with, or release birds from, cowbird traps. Traps are serviced regularly and are an essential component of the endangered species management program.

ii) Level 2 restrictions include all Level 1 restrictions, plus:

G) Occupation of habitat areas is limited to drive-through on existing trails, or emergency stop only. No bivouac or other long-term posts are permitted within habitat areas. Long-term is defined as exceeding 2 hours in duration.

H) No use of obscurant smokes or other chemical agents is allowed in or within $100 \mathrm{~m}$ of habitat.

8) In addition to habitat protection and management, implement monitoring and research programs for the goldencheeked warbler and black-capped vireo.

a) Golden-cheeked warbler:

(i) Document population trends and assess population status.

(ii) Refine and validate population viability models for warblers on Fort Hood.

(iii) Evaluate the relationship between habitat quality and warbler abundance and productivity.

(iv) Evaluate fire-related dispersal patterns of golden-cheeked warblers.

(v) Evaluate effects of recreational off-road bicycle use on warbler demography and productivity.

b) Black-capped vireo: 
(i) Monitor populations in three intensive study areas (TA 44B, East Ranges (TA 2, 5A and 5B) and West Fort Hood) and the Live Fire Area.

(ii) Monitor successional development of habitat and vireo colonization in areas burned during the February 1996 fire.

(iii) Refine and validate population viability models for black-capped vireos on Fort Hood.

(iv) Determine predator types and effects of depredation on vireo nests.

c) Continue to allow safe access to training and Live-Fire Areas for vireo and warbler surveys during the period of March 15 through July 31 to ensure that equivalent data is collected for study areas both in and out of the Live Fire Area. Under the current training schedule and FY 2000 field season, this will consist of data collected at each study site at a minimum of once every 14 days. In future field seasons, this schedule of data collection may be modified on a case by case basis to accommodate shifts in training schedules due to upgrades in training procedures, upon written notification to the Service. It is important that the integrity of data collected from existing vireo and warbler productivity, predation and population trend studies is maintained.

d) Continue to generate color sequences far range-wide color banding of vireo and warblers through cooperation with the Service.

9) Institute protective measures for the bald eagle and whooping crane.

a) Bald eagle:

(i) Minimize disturbance from low-level helicopter flights and other aviation assets.

(ii)When bald eagles are first observed in autumn, notify the Fort Hood air-space coordinator, and implement the no-fly zone. This zone is situated on and near Belton Lake in parts of training areas $3 \mathrm{~B}, 6 \mathrm{~A}, 6 \mathrm{~B}$, and $7 \mathrm{~B}$.

(iii) Flight restrictions will be lifted when no bald eagles have been observed for a period of two weeks.

b) Whooping crane:

(i) Establish protocols for notifying G3, Range Control and other appropriate training and operations organizational elements if cranes are observed.

(ii) Temporarily suspend training activity in areas where individual cranes are observed.

(iii) Monitor cranes until they have departed installation lands so that temporary training restrictions can be lifted as soon as possible.

10) Restrict recreational use in endangered species habitat.

a) If Fort Hood chooses to allow non-governmental off-road vehicle use, motorized ORV use shall be restricted to the 50 acre developed track site within TA 34D. The use of non-motorized ORV's (mountain bikes) shall be restricted to the mountain bike park at the Belton Lake Outdoor Recreation Area (BLORA).

b) Establish a study that will attempt to band and age vireos using the habitat adjacent to TA 34D, in order to determine site fidelity and extent of habitat use, if authorized recreational off road vehicle use is continued.

c) Continue to monitor mountain biking activities at BLORA, through the 5-year term of the ESMP, to determine the impacts to warblers.

\section{REPORTING REQUIREMENTS}

The results of all surveys and studies specified in this biological opinion shall be reported to the Service's Austin Office by December 1 of the year the studies are conducted.

Upon locating a dead, injured, or sick individual of an endangered or threatened species, initial notification must be made to the Service's Law Enforcement Office in San Antonio, Texas (Telephone 210/681-8419) and the Austin Fish and Wildlife Service Office (512/490-0057). Care should be taken in handling sick or injured individuals to ensure effective treatment and care, and with dead specimens to preserve biological materials in the 
best possible state for analysis of cause of death. It is the responsibility of the finder of the dead, sick, or injured endangered or threatened individuals not to distirb the site unnecessarily.

\section{CONSERVATION RECOMMENDATIONS}

Section 7(a)(1) of the Act directs Federal Agencies to use their authorities to further the purposes of the Act by carrying out conservation programs for the benefit of threatened and endangered species or candidate species. Conservation recommendations have been defined as suggestions of the Service regarding discretionary measures the consulting Federal agency should take to minimize or avoid adverse effects of a proposed action on a listed species or designated critical habitat, or regarding the development of information.

In addition to the conservation measures identified in the 1993 Biological Opinion, the Service also provides the following recommendations to promote the conservation of species of concern and other rare species.

A) Conduct an installation-wide survey for the Texas horned lizard (Phrynosoma cornutum), a State listed threatened species. Institute additional conservation recommendations for the horned lizard, as outlined in the 1999 Annual Report of Endangered Species Monitoring and Management at Fort Hood, Texas (The Nature Conservancy 2000).

If these conservation recommendations are adopted or must be modified due to unforeseen circumstances, please coordinate with the Austin Fish and Wildlife Service Office to provide the best approach to conservation. Please provide documentation of implementation of reasonable and prudent measures as they are fulfillect.

\section{REINITIATION-CLOSING STATEMENT}

Fort Hood will reinitiate consultation should significant changes need to be made to the ESMP or the Grazing MOU at the time of their respective 5 year reviews.

This concludes formal consultation on the action outlined in the request. As provided in 50 CFR Sec. 402.16, reinitiation of formal consultation is required where discretionary Federal agency involvement or control over the action has been retained (or is authorized by law) and if: (1) the amount or extent of incidental take is exceeded; (2) new information reveals effects of the agency action that may affect listed species or critical habitat in a manner or to an extent not considered in this opinion; (3) the agency action is subsequently modified in a manner that causes an effect to the listed species not considered in this opinion; or (4) a new species is listed that may be affected by the action. In instances where the amount or extent of incidental take is exceeded, any operations causing such take must cease pending reinitiation.

Sincerely,

/s/ David C. Frederick

Supervisor

\section{Literature Cited}

Hayden, T.J., J.D. Comelius, H.J. Weinburg, L.A. Jette, and R.H. Melton. 1998. Endangered Species Management Plan for Fort Hood, Texas; FY99-03. Public review draft. Prepared for Arny Corps US Engineers, Headquarters III Corps \& Fort Hood. USACERL Technical Report 98/Draft. Fort Hood, Texas. 
Hayden, T.J., J.D. Cornelius, H.J. Weinburg, L.A. Jette, and R.H. Melton, 2000. Endangered Species Mandagement Plan for Fort Hood, Texas; FY00-04. Revised draft. Prepared for Army Corps US Engineers, Headquarters III Corps \& Fort Hood. USACERL Technical Report 00/Draft. Fort Hood, Texas.

National Park Service. 1992. Western region fire monitoring handbook. U.S. Department of the Interior, National Park Service, San Francisco, California.

Natural Resources Conservation Service (NRCS). 1998. Fort Hood Vegetative Resource Inventory. U.S. Department of Agriculture. Fort Hood, Texas.

Texas State Data Center (TSDC). 1998. Texas County Census Data (www.census.gov/ftp/pub/epcd/cbp/map). Texas A\&M University, College Station, Texas.

The Nature Conservancy (TNC). 1998. Summary of 1997 Research Activities. Compiled by L.L. Sanchez. Texas Conservation Data Center, The Nature Conservancy, Fort Hood, Texas.

The Nature Conservancy. 2000. Endangered species monitoring and management at Fort Hood, Texas: 1999 annual report. Fort Hood Project, The Nature Conservancy of Texas. Fort Hood, Texas.

U.S. Department of Defense, Department of the Army - Fort Hood. 1999a. Memo dated 16 August 1999: Response to Request for Supplemental Irformation for the Biological Opinion.

U.S. Department of Defense, Department of the Army - Fort Hood. 1999b. Memo dated 17 December 1999: Response to Request for Supplemental Information for Amendment to the Biological Opinion Concerning the ITAM Juniper Clearing Program.

U.S. Department of Defense, Department of the Army - Fort Hood. 1999c. Juniper Management Program Overview Slides.

U.S. Fish and Wildlife Service. 1992. Golden-cheeked Warbler (Dendroica chrysoparia) Recovery Plan. Albuquerque, New Mexico.

U.S. Fish and Wildlife Service. 1993. Biological Opinion on Fort Hood Military Reservation. Austin, Texas.

U.S. Fish and Wildlife Service. 1996a. Black-capped Vireo Population and Habitat Viability Assessment Report. Compiled and edited by Carol Beardmore, Jeff Hatfield, and Jim Lewis in conjunction with workshop participants. Report of a September 18-21, 1995 workshop arranged by the U.S. Fish and Wildlife Service in partial fulfillment of U.S. National Biological Service Grant No. 80333-1423. Austin, Texas.

U.S. Fish and Wildlife Service. 1996b. Golden-cheeked Warbler Population and Habitat Viability Assessment Report. Compiled and edited by Carol Beardmore, Jeff Hatfield, and Jim Lewis in conjunction with workshop participants. Report of an August 21-24, 1995 workshop arranged by the U.S. Fish and Wildlife Service in partial fulfillment of U.S. National Biological Service Grant No. 80333-1423. Austin, Texas.

U.S. Fish and Wildlife Service. 1998. Summary of Meeting Highlights Resolution of Fort Hood Endangered Species and Grazing Management Issues. 


\title{
Appendix B: Fort Hood Fire Management and Protection Policies
}

\author{
Fort Hood Fire Management and Protection Policies
}

\section{Background}

The following fire management policies were implemented subsequent to a series of major uncontrolled burns on the installation during February 1996. Installation trainers and natural resources staff developed these policies in consultation with the U.S. Fish and Wildlife Service.

Three major fires broke out on February 21, 22 and 23, 1996 burning approximately 2313 ha of golden-cheeked warbler habitat and 415 ha of black-capped vireo habitat. Approximately 75 percent of the burned area was described as Burn Severity Index Level 1 or 2, the most severe burn ratings on the scale developed by the USDI, National park Service (1992). Visible characteristics of level 1 intensity sites include complete consumption of litter and duff layers, leaving fine white ash, and consumption of all above-ground plant parts, leaving only major stems and trunks.

\section{Installation Fire Danger Rating Protocols}

Fort Hood currently has a fire danger rating system in place to alert trainers when pyrotechnic operation should be limited or halted based on current (daily) weather and estimated moisture content of vegetation and soil. This system (OPLAN 8-93, "Operation Brush Fire") included the following fire danger ratings:

Condition Green: No restrictions on training. Troops may use pyrotechnics and incendiary munitions for training.

Condition Amber: Caution must be taken in use of pyrotechnics. Aerial flares are not to be used outside the impact area. Other pyrotechnics are to be used only in roadways, tank trails, in areas clear of vegetation, or in containers. 
Condition Red: No pyrotechnics or incendiary munitions authorized for training purposes.

Condition Red With Waiver: Once a risk assessment is conducted by Range Control and the recommendation for training with waiver is approved by the $\mathrm{G} 3$, specific restrictions are imposed on training units. Appendix D. FH Reg 350-40 highlights the waiver request procedures for training units.

In consultation with Range Control, the Environmental Division office recommends to the Director of Public Works any change in range conditions. The DPW, as part of the fire response council ensures adequate fire department resources are $\mathrm{n}$ hand to respond to potential fires caused by fire waivers. When $\mathrm{G} 3$ has questions or concerns on mission essential ranges that have habitats; Range Control will consult the Environmental Division, through the natural Resources staff, who have the responsibility for waiver recommendations under any range condition.

\section{Installation Fire Prevention and Protection Measures}

Fort Hood is implementing the following fire prevention and protection measures to offset take of vireo and warbler habitat as a result of the February 1996 fires.

1. Increase fire prevention and response efforts.

a. Assess current operations plan for preventing and responding to fires, identify deficiencies, and implement more effective fire prevention, response, and training programs.

b. Restructure Fire Danger Rating (FDR) program.

1. Develop and implement a scientifically-based formula for determining FDRs and formalize internal procedure for changing FDR level.

2. Limit waivers under "Red" conditions for other than mission essential training to ranges where fire is not likely to threaten habitat.

3. Ensure the Natural Resource Branch staff have input into the waiver staffing process and is furnished copies of approved fire waivers.

4. Present proposed program revisions to the Austin Ecological Services Field Office for review. 
c. Develop a 5-year plan to build and/or upgrade fire access roads and firebreaks. This plan should include firebreaks both in and out of the live-fire area, with a maximum 100-meter wide firebreaks in habitat areas and 200meter firebreaks in nonhabitat. The order of firebreak construction will be prioritized based on the likelihood that potential fires will threaten habitat. Once the location and size of the fire-breaks have been determined, estimate the acreage of vireo and warbler habitat that would be impacted. To promote vireo dispersal corridors and help prevent or slow crown fires, maintain firebreaks in an early successional stage. The plan shall be presented to the Austin Ecological Services F ield Office for review prior to its implementation.

d. Upgrade fire-fighting capabilities.

1. Purchase three to five new buckets for aerial delivery of water and improve their maintenance and storage.

2. Purchase or fabricate two track-based fire fighting vehicles.

3. Purchase three HMMV-based fire fighting vehicles.

4. Update communications equipment.

5. Fabricate off-road-capable fire trucks

6. Investigate restationing or establishment of a 51-M (Military Firefighter) unit at fort Hood.

7. Update Operations Plan to include an emergency response program for fire fighting.

2. Initiate research on the effects of the burn and additional studies to benefit the vireo and warbler.

a. Study the dispersal patterns of warblers displaced from the burned areas, and warbler use of isolated patches and fragmented habitat within and peripheral to the fire area. (WRP tasks 1.43 and 1.442)

b. Monitor the successional development of vireo habitat and vireo colonization after the fire. Expand current monitoring efforts to include new colonization of burned areas. (VRP tasks 1.43 and 1.442) 
c. Conduct a predation study on warblers and vireos and implement appropriate measures if some level of predator control is determined to be necessary to increase reproductive success. (WRP tasks 1.21, 1.24, 1.25; VRP tasks 1.5, 2.4 and 3.4)

Research proposals will be submitted to USFWS for independent peer review prior to implementation in accordance with 59 FR 34270. The primary purpose of this review is to ensure that any information used by the USFWS to implement the Endangered Species Act represents the best scientific and commercial data available.

3. Refine mapping efforts to enhance endangered species information management on F ort Hood.

a. Using prefire and post-fire satellite imagery and/or aerial photography, develop an accurate map to determine acreage and distribution of habitat burned in the 1996 fires.

b. Produce a new Training Area map with endangered species overlay for Fort Hood that incorporates the latest information available regarding the current distribution of endangered species habitat and endangered species burn protection areas. For mapping purposes, all warbler habitat that burned should be considered to be vireo habitat. This map shall be updated every five years. Between updates, ground truthing surveys will be conducted to validate accuracy of the map. 


\title{
Appendix C: Fort Hood Endangered Species Training Guidelines
}

\author{
TRAINING GUIDELINES \\ FOR USE OF \\ ENDANGERED SPECIES HABITAT
}

Guidelines are implemented at two levels. Level 1 applies from 1 September through 28 February. Level 2 is more restrictive, and applies from 1 March through 31 August. The hierarchical structure allows greater utilization of habitat during the period when the endangered species are not present, while providing adequate protection during the nesting period. Guidelines should be used in conjunction with a 1:50,000 training area map with current endangered species habitat overlay.

\section{LEVEL 1 RESTRICTIONS}

(applicable from 1 September through 28 February)

1. Report all fires to Range Control. Do not start fires.

2. Use previously established firing points, fighting positions, and emplacements only. All digging must be cleared by the Directorate of Public Works (DPW).

3. Comply with range rules regarding use of flares, incendiary munitions, etc. Ensure that firefighting equipment and personnel on hand are in compliance with Fire Danger Rating SOP.

4. Park equipment in open areas only. Do not cut brush or trees for camouflage, road blocks, or other purposes.

5. Use existing roads and trails. Do not drive vehicles through or over woody vegetation.

6. Do not tamper with, or release birds from, cowbird traps. Traps are serviced regularly and are an essential component of the endangered species management program. 
LEVEL 2 RESTRICTIONS

(applicable from 1 March through 31 August)

\section{ALL LEVEL 1 RESTRICTIONS, PLUS THE FOLLOWING:}

7. Occupation of habitat areas is limited to drivethrough on existing trails, or emergency stop only. No bivouac or other long-term posts are permitted within habitat areas. Long-term is defined as exceeding 2 hours in duration.

NOTE: Due to difficulty in providing adequate detail at 1:50,000 map scale, habitat overlays sometimes obscure open areas within habitat blocks where some limited long-term use is possible. Proposed use of open areas within habitat must be coordinated with and approved by DPW, Natural Resources Management Branch personnel on a case-by-case basis. Arrange for site visit during earliest planning stages.

8. No use of obscurant smokes or other chemical agents in or within 100 meters of habitat.

Guidelines are intended to minimize actions which cause physical damage to habitat or disturb nesting. Careful planning and use of current habitat maps are necessary to avoid conflict and possible disruption of training activities in the field. If in doubt regarding acceptable locations or activities in or near habitat, contact DPW, Natural Resources Management Branch at 287-2885. 


\section{Appendix D: Population Viability Analyses of the Golden- cheeked Warbler and the Black-capped Vireo on Fort Hood, Texas}

POPULATION VIABILITY ANALYSES OF THE GOLDEN-CHEEKED WARBLER AND THE BLACK-CAPPED VIREO ON FORT HOOD, TEXAS.

Prepared by: Robert H. Melton, Ph.D.; ERDC/CERL (CN-N)

\section{March 1996}

\section{Objectives}

A population viability analysis (PVA) is a set of computer simulations, using the best available data for a given population, the goal of which is estimation of the likelihood that the population will go extinct over a given time frame. The objective of the present set of PVAs is to determine vulnerabilities to extinction for the Golden-cheeked Warbler and the Black-capped Vireo on F ort Hood, to determine the best methods for minimizing these extinction probabilities, and to determine the amount of habitat required by these species to assure their survival on Fort Hood in the future.

\section{Methods}

The methodol ogy used here was modified from the methods used for PVAs of the Golden-cheeked Warbler and the Black-capped Vireo during two Population and Habitat Viability Workshops concerning these species, conducted during the fall of 1995, and sponsored by the U.S. Fish and Wildlife Service (USFWS 1996).

Certain aspects of the methods used here were the same for both the Goldencheeked Warbler and the Black-capped Vireo. The PVAs presented here were done using the METAPOP subprogram of the RAMAS/GIS software package 
(Akçakaya 1994) designed specifically for PVA. The probability of extinction was estimated over a period of 100 years (time steps). No immigration or emigration of birds from Fort Hood was assumed to be happening. No catastrophic years were assumed to occur. Density dependence was of the "ceiling" type, and no variation or temporal trend in carrying capacity was assumed. The species on Fort Hood were treated as single populations, not metapopulations. Temporal variations in both fecundity and survival rates were modeled using the "lognormal" distribution option. Fecundity and survival rates were assumed to vary independently, and equation 5 of Goodman (1960) was used to estimate the variance of the product of fecundity and survival when estimating matrix parameters under either pre-breeding or post-breeding census schemes. Demographic stochasticity was used in all simulations. Estimates of survival rates for each age class were performed from mark-recapture data using standard markrecapture methods ( $\mathrm{im}$ Nichols and J im Hines, pers. comm.). Carrying capacity was varied across a similar range of values from 50 to 5000 territorial males for both species.

The parameter estimates entered into the PVA models for the Golden-cheeked Warbler and the Black-capped Vireo are presented in Table 6.

The Golden-cheeked Warbler population was modeled using a post-breeding census scheme (see Akçakaya 1994, or Burgman et al. 1993 regarding pre- vs. postbreeding census issues). Fecundity estimates and their temporal variances were calculated from Fort Hood data for three age-classes of territorial males, fledglings (HY), second-year males (SY), and after-second-year males (ASY). Yearly survival rates could be calculated for $\mathrm{HY}$ males and after-hatch-year (AHY) males, and the temporal variance in survival rate could be calculated only for ASY males. Variance in HY survival rate (VSHY) was assumed to be equal to that of the variance in ASY survival (VSAHY). However, a second set of simulations was also performed using VSHY $=2 \times \mathrm{VSAHY}$, to model the possibility that temporal variance in juvenile survival was greater than that of post-juvenile survival. The starting population size was conservatively estimated to be approximately twice the number of male warblers documented on Fort Hood in 1995, which was 797 territorial males. (Note: A more realistic estimate of the 1995 warbler population might be approximately 3200, given that the documented males represent only about 25 percent of the total warbler habitat present on the fort (Maria Tolle, pers. comm.)). Although the observed survival rate for HY males on Fort Hood was .30, simulations using this value went rapidly to extinction in all cases examined. Given that survival rates from Fort Hood do not differentiate between losses due to deaths vs. losses due to permanent emigration from the field study sites, this value for HY survival is probably an un- 
derestimate. Therefore, the HY survival rate used in the present simulations was increased to .5, a generous but not unrealistic number.

The Black-capped Vireo was modeled using a pre-breeding census scheme. The difference in the models used for the Golden-cheeked Warbler vs. the Blackcapped Vireo was primarily due to differences in the availability of data on females, since some data was available for female vireos, where there was almost none whatsoever available for the warbler. The model used was

$N(t+1)=[(F A H Y(t) \times S H Y(t))+S A H Y(t)] \times N(t)$

where $\mathrm{N}(\mathrm{t})$ is the number of breeding $(\mathrm{AHY})$ females just prior to breeding in year $t, F A H Y(t)$ is the seasonal fecundity rate of $A H Y$ females for that year, $\mathrm{SHY}(\mathrm{t})$ is the yearly survival rate of HY females, and SAHY(t) is the yearly survival rate of AHY females. This model has only one explicit age class (AHY) in the RAMAS matrix model, but $\mathrm{HY}$ survival rate and its variance are implicitly used in calculating $\mathrm{N}(\mathrm{t}+1)$ at each time step. Fecundity of AHY females was calculated from Fort Hood data. The FAHY estimate from Fort Hood data was .96 females per territorial female. However, the model in its present parameterization predicts certain extinction if mean seasonal fecundity is less than 1 female per territorial female. Therefore, in the present simulations, a fecundity of 1 was used throughout. This was not unreasonable, since fecundities are probably underestimated in the field. The value of temporal variance for FAHY used here was derived from analysis of data collected from Wichita Mountains National Wildlife Refuge, Oklahoma, 1988-1994 (Pease and Grzybowski, unpublished data). Use of the Fort Hood temporal variance (VFAHY $=.0784$ ) gave similar results. SHY and SAHY estimates were also taken from the Wichita Mountains data. These estimates are adjusted for permanent emigration from the study area, and were thus used in preference to F ort Hood data. Temporal variance of SAHY was estimated from data for males, insufficient data from females being available. The starting female vireo population size was conservatively estimated to be approximately 500, based on the number of male warblers documented on Fort Hood in 1995, which was 299 territorial males,assuming a 1:1 ratio of males to females, and assuming also that there were roughly 200 more vireos present on Fort Hood than were actually documented.

\section{Results}

Figure 6 shows the predicted relationship of the probability of extinction over 100 years $(=\operatorname{Pr}(E))$ to carrying capacity of the environment K. For the Goldencheeked Warbler, $\operatorname{Pr}(\mathrm{E})$ is low in both the low VSHY and high VSHY scenarios for values of $K$ greater than 1000 (Figure 6 A, B). However, $\operatorname{Pr}(E)$ increases 
dramatically for $K$ lower than 1000. Note, however, that for $K=1000$, the number of territorial males present at the end of 100 years is only approximately 400-500 birds, a relatively low number (Figure 7 A, B). To achieve a male population of 1000 or more at the end of 100 years, a carrying capacity $K$ of at least 2200 to 3000 males would be required.

For the Black-capped Vireo, $\operatorname{Pr}(E)$ is substantially higher than was seen for the Golden-cheeked Warbler at all levels of carrying capacity K (Figure 6 C, D). When $\mathrm{K}$ is greater than 1000 territorial females, $\operatorname{Pr}(E)$ is constant over all values of $\mathrm{K}$, with a value in the range of approximately .25 to .35. As in the case of the warbler, $\operatorname{Pr}(\mathrm{E})$ increases dramatically for $\mathrm{K}$ lower than 1000. However, in the case of the vireo, the PVA model does not predict any level of $K$ that would give an expected population of 1000 , or even 500 , after 100 years (Figure 7 C, D). This is due to the fact that the model, as presently parameterized, predicts steady decline in expected vireo population density over the 100 year interval at all levels of carrying capacity (not shown), which was not the case for the warbler model.

\section{Discussion}

A number of caveats are warranted before interpretation of the present analyses. A PVA is only as good as the data that are entered into it. In the present case, some parameters used are of questionable accuracy. Because data on HY emigration rates and distances are sparse for both species at present, the values used for SHY in both the warbler and vireo simulations are educated guesses rather that estimates taken from the data itself, although in the case of the vireo an attempt at correction for emigration using the assumption of a stationary population density was done. Fecundities presented here are probably also underestimated, because they are based on observation of fledglings after they have left the nest, when they are hard to find. In the future, fecundities for the vireo may be corrected by utilizing information from data on counts of nestlings in the nest just prior to fledging, but this possibility is unlikely for the warbler, whose nests are well-hidden in tall trees, and are generally inaccessible for intensive observation. The values used for present starting population sizes on Fort Hood are also rather rough educated guesses, in need of improvement. Many of the model assumptions (constant carrying capacity, no immigration or emigration, no catastrophes) are not entirely realistic. In particular, immigration into the population from lands surrounding Fort Hood could substantially reduce the predicted probabilities of extinction for these species. However, there is as yet no data available on immigration of warblers or vireos from other population sources. 
These caveats notwithstanding, some striking features emerge from these analyses. Most striking, perhaps, is the sharp increase in the likelihood of extinction as carrying capacity is reduced below 1000, true for both the warbler and the vireo models. This sharp increase in extinction at low $\mathrm{K}$ is due primarily to the enhanced risks that accrue from random population fluctuations at low population sizes, and represents an extinction "vortex" for small populations (Gilpin \& Soule 1986) that draws populations even further into trouble as population size goes down. From a management standpoint, provision of enough habitat for a population size of at least 1000 singing males would seem to be strongly recommended. However, carrying capacities well beyond 1000 may be necessary to preserve these populations at high densities in the distant future. For the warbler, as stated above, two to three times more habitat would be required to achieve a "safe" density of 1000 singing males at the end of 100 years. For the vireo model, under the parameters used here, no amount of habitat would appear to achieve such a "safe" density, and the more habitat conserved or created, the better.

A second striking feature of these analyses is the high probability of extinction seen for the Black-capped Vireo, compared with the Golden-cheeked Warbler at all carrying capacities. This does not seem to be an artifact of the lower value of HY survival used for the vireo compared with the warbler, because simulations run using a vireo HY survival rate of .5 (the same as used for the warbler) made little difference in the result. The difference seems to be due to lower average fecundity, higher variance in fecundity, and lower starting population sizes, in the vireo than in the warbler.

The maximum density recorded for Golden-cheeked Warblers in Training Are 13B (the Warbler Intensive Study Area) was .235 territorial males per hectare, or $4.26 \mathrm{ha} / \mathrm{male}$. If we accept this as a dense warbler population (as seems likely) it would take at least 4260 ha of prime warbler habitat to conserve the population for 100 years at a low probability of extinction, but it would take approximately 8500 to 17,000 ha or more of such prime habitat to conserve the warblers and also expect a population of over 1000 singing males after 100 years. The present amount of warbler habitat on Fort Hood is estimated to be approximately 21,496 ha. This would appear to be more than sufficient to conserve the Goldencheeked Warbler over the next 100 years, assuming that at least 18 percent, and preferably 36 to 55 percent, of this is prime habitat comparable to that of Training Area 13B, and that the habitat is sufficiently unfragmented such that is usable by the warblers.

The average density recorded in six core vireo study areas over the previous five years was .240 territorial males/ha, or $4.17 \mathrm{ha} / \mathrm{male}$. If we accept this figure as 
representing a dense vireo population, it would take at least 4166 ha of vireo habitat to keep the probability of extinction below .4, however, this is still an unacceptably high probability of extinction. The present amount of vireo habitat on Fort Hood is difficult to assess, due to the changing, successional nature of the scrub habitat that it prefers. Estimates based on visual inspection of aerial photographs from 1987 of Fort Hood yield a value of approximately 1300 ha of visually discernable vireo habitat, enough for about 312 singing males, which is clearly insufficient to keep $\operatorname{Pr}(\mathrm{E})$ below .40. A recent GIS analysis of Fort Hood, using the functional relationship of vireo density on the six core areas to a habitat index based on 1992 Landsat-TM imagery (Melton, unpubl.), suggests that there may be as much as approximately 14,000 ha of Black-capped Vireo habitat (of varying quality) on the fort at this time, and predicts a carrying capacity of 2600 singing males for Fort Hood as a whole. However, this study needs to be ground-truthed. Beyond increasing the amount of available vireo habitat as much as possible, it is also recommended that nest success, and thus seasonal fecundity, be increased as far as possible. Cowbird control measures underway at present on Fort Hood would appear to be a crucial first step in this direction. Future steps could also include control of avian, mammalian, and reptilian predators where feasible, and a study of nest site habitat characteristics, and of whether certain habitat features provide protection from predators and/or nest parasites. The yearly survival rate of HY birds should also be maximized, but this would be difficult to achieve and monitor, since much of the HY mortality will occur off the base during migrations and in Mexico during the non-breeding season, and since the amount of dispersal of $\mathrm{HY}$ individuals to new local ities outside of the main study areas, as distinct from $\mathrm{HY}$ deaths, is difficult to accurately assess.

In conclusion, the results presented here suggest that, of the two endangered passerine bird species present on Fort Hood, the Golden-cheeked Warbler is reasonably safe from extinction on the fort for the foreseeable future. The Blackcapped Vireo, however, appears quite vulnerable to extinction, and warrants a high priority for habitat conservation and management efforts. 



\section{Appendix E: "Environmental}

Assessment" and "Finding of No Significant Impact" for the Fort Hood Endangered Species Management Plan 


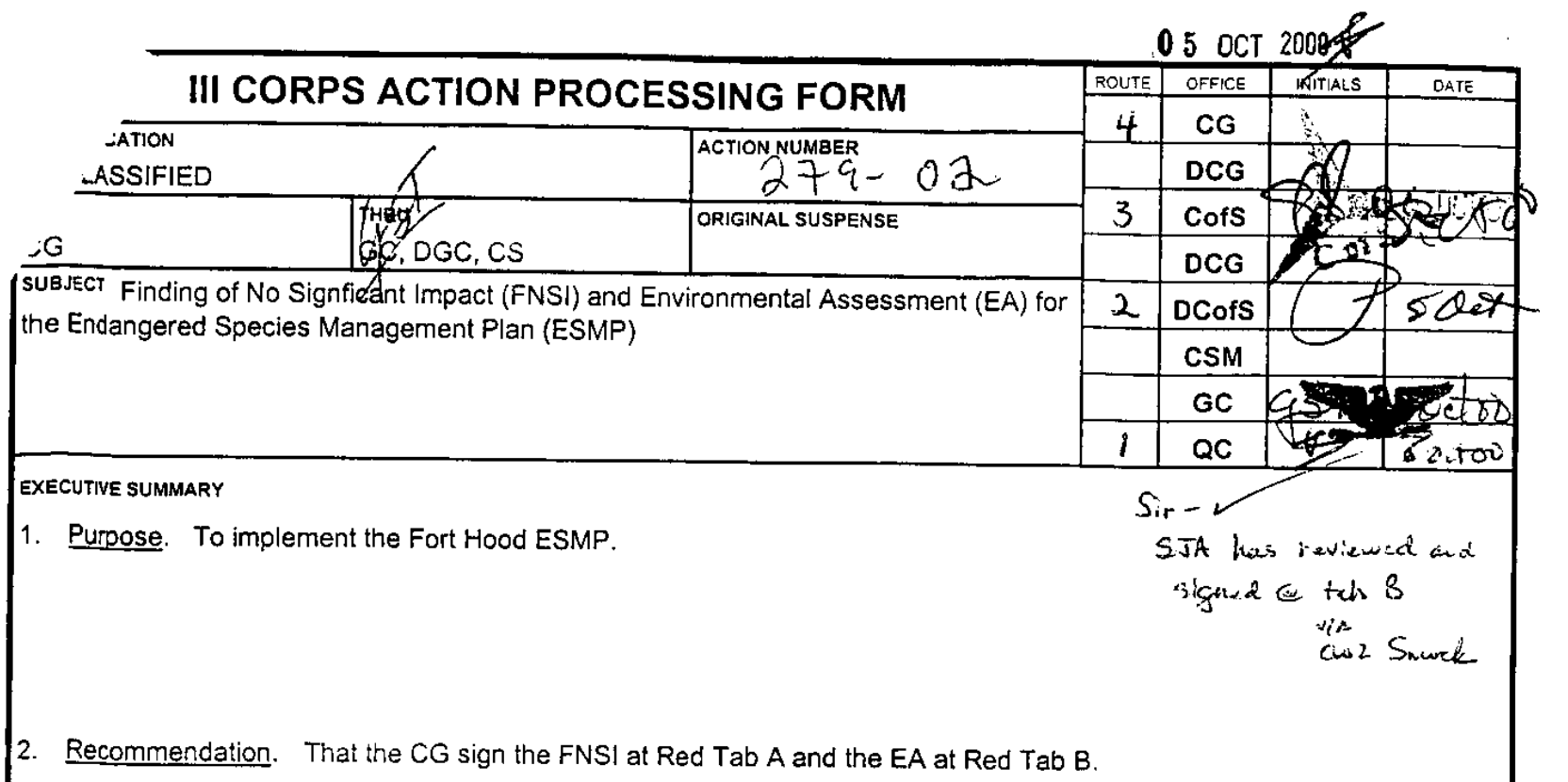

3. Discussion.

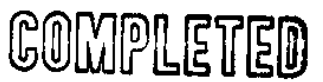

a. The development of an Endangered Species Management Plan (ESMP) was contracted to the U.S. Army Construction Engineering Research Laboratory (USA-CERL). The working team at Fort Hood included representatives from G3, SJA, and DPW. Development of this plan has taken more than 5 years and has included consultation and coordination with numerous private individuals, organizations, state and federal regulatory agencies.

b. The U.S. Fish and Wildife Service (USFWS), the regulatory authority for Endangered Species Act (ESA) compliance, has reviewed the draft ESMP and determined that implementation of the plan as proposed is sufficient to meet agency requirements formitigation of the impacts of the military mission on endangered species populations at Fort Hood.

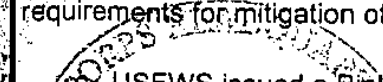

Q USFWS issued a Biplogical Opinion to Fort Hood on 26 July 2000 stipulating Terms and Conditions under which If gidental Take for military operations will be granted. The ESMP is the implementation plan for those Terms and Conditions. The BiblogitalOpinlon states that in order for Fort Hood to avoid additional formal consultation, the ESMP should be approved fand inglemented withing oys: (on or before 24 October 2000).

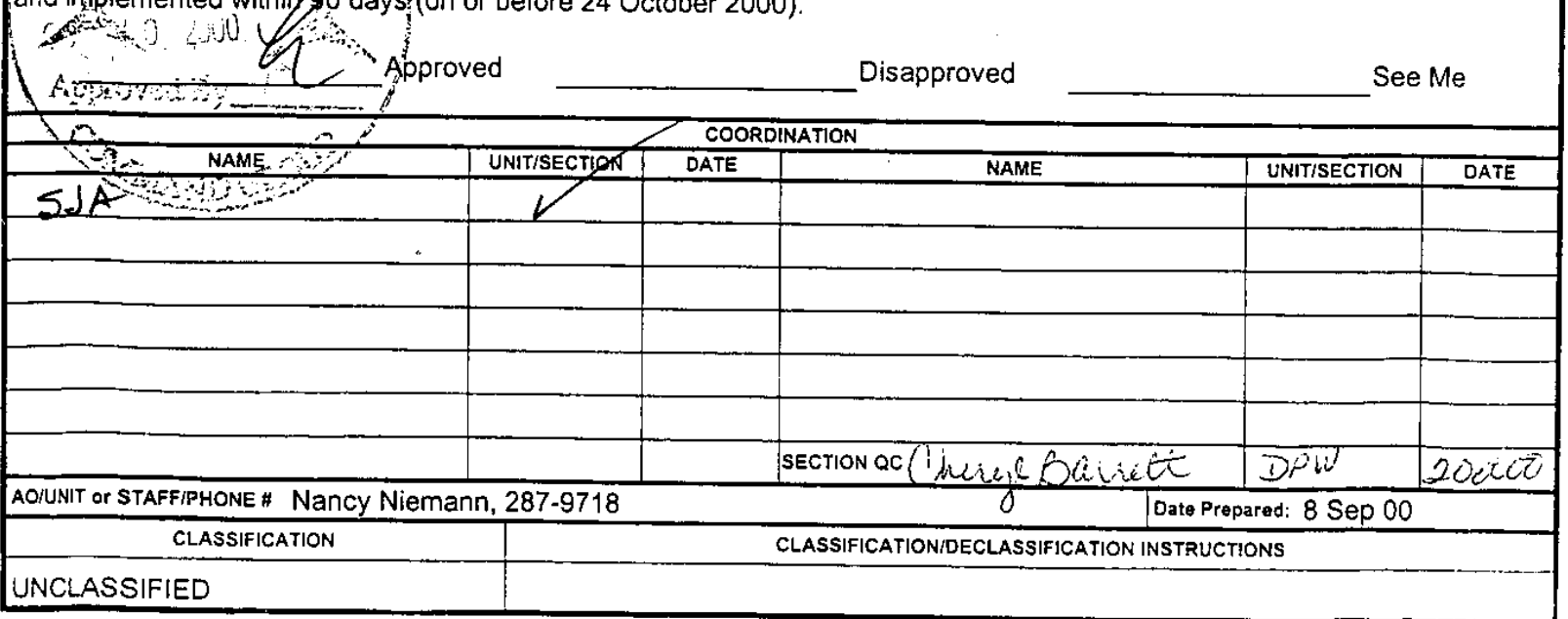

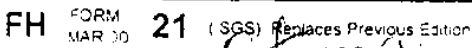

u 3 SEP - 2000 : : 
ECT Finding of No Significant Impact (FNSI) and Environmental Assessment (EA) for the Endancarsd Species
nagement Plan (ESMP)

d. A primary provision of the ESMP is the designation of habitat for endangered species as Core Habitat or Noncore
Habitat. Through extensive coordination within the Fort Hood working team, mission-essential maneuver training areas identified and designated as Noncore habitat. This designation working team, mission-essential maneuver training areas were restrictions throughout the western maneuver area, with increased mon the ESMP allows for relaxation of maneuver training designations are concentrated in the eastern portion of the installation whering by DP to determine effects. Core habitat

e. Under the previous (1993) Biological Opinion, Fort Hood was required to impose training restrictions on every acre of habitat for endangered species. The proposed ESMP reduces restrictions on 19,380 acres of habitat and provides for
increased incidental take of habitat over the 5-year term of the plan.

f. Implementation of the plan is estimated to cost $\$ 18.1$ million over 5 years. Implementation is subject to availability of funds. Funds for implementation are requested through the EPR process, provided by HQ-DA, and administered through
DPW, Natural Resources. The ESMP is an (n) Integrated Natural Resource Management Plan for Fort Hood.

\section{Encls}

as

\author{
$N_{-\alpha} \Lambda_{\text {P-at }}$ \\ MICHAEE W. PRATT \\ COL, EN \\ Director of Public Works
}




\section{FINDING OF NO SIGNIFICANT IMPACT IMPLEMENTATION OF ENDANGERED SPECIES MANAGEMENT PLAN}

\subsection{NAME OF ACTION}

Proposed implementation of the Endangered Species Management Plan for Fort Hood, Texas: FY 01-05.

\subsection{DESCRIPTION OF PROPOSED ACTION AND ALTERNATIVES}

\subsection{Proposed Action.}

The US Department of the Army proposes to implement the Endangered Species Management Plan for Fort Hood, Texas for FY 01-05.

\subsection{No Action Alternative.}

Under the No Action Altemative, Fort Hood would continue to operate under the US Fish and Wildlife Service 1993 biological assessment.

2.3 Alternative Actions Considered for Implementation Under the Preferred Alternative.

Reduce Nest Parasitism by Brown-Headed Cowbirds - Preferred alternative is to implement a year-round trapping and shooting effort during the nesting season to destroy breeding female cowbirds in the Fort Hood population.

Population Monitoring Activities - Preferred alternative is to band alternative adults, nestlings and juveniles to assess adult and first-year survival and dispersal. Nest visits will be conducted to evaluate levels of nest parasitism, depredation, and productivity.

Training Restrictions - Preferred alternative is to lift training restrictions in non-core habitat areas to allow mission-critical training opportunities in those designated areas while maintaining training restrictions in the core habitat areas.

\subsection{SUMMARY OF ENVIRONMENTAL EFFECTS}

No significant cumulative adverse effects on biological, cultural, or socioeconomic resources are anticipated from implementation of the preferred alternative. Implementation of the preferred alternative will maintain progressive biological management of endangered species on Fort Hood while maintaining the Army's ability to effectively train. Additional monitoring, research, and mitigation requirements under the proposed ESMP will provide mechanisms to recognize, evaluate, and rectify any adverse effects before cumulative, irreversible impacts occur. 


\subsection{CONCLUSION}

Based on the findings of this Environmental Assessment, no significant environmental impacts would occur under the proposed action. Therefore, an issuance of a Finding of No Significant Impact (FONSI) is warranted and an Environmental Impact Statement (EIS) is not required. This document and the Environmental Assessment prepared for the proposed action fulfill the requirements of the National Environmental Policy Act of 1969 (NEPA), as amended, the Council of Environmental Quality (CEQ) regulations implementing NEPA, and Army regulation 200-2, which supplements CEQ guidelines.

SIGNED: Ston to tatete

LEON J. LAPORTE

Lieutenant General, USA

Commanding 
DEPARTMENT OF THE ARMY

HEADQUARTERS III CORPS AND Fort Hood, TX

ENVIRONMENTAL ASSESSMENT

September 2000

\section{Endangered Species Management Plan}

FOR

FORT HOOD, TEXAS

September 12, 2000

PREPARED BY:

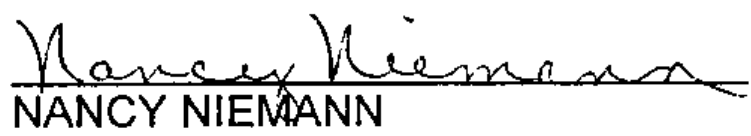

Environmental Division

Directorate of Public Works
TECHNICAL REVIEW BY:

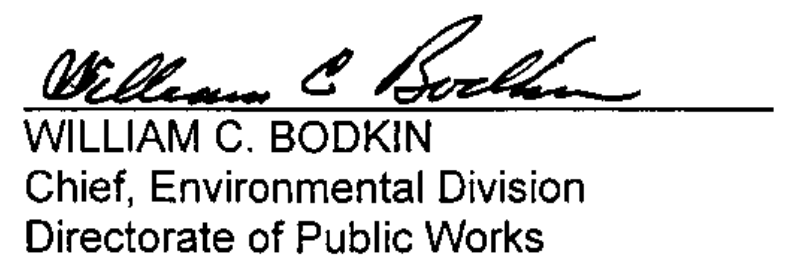

LEGAL REVIEW BY:
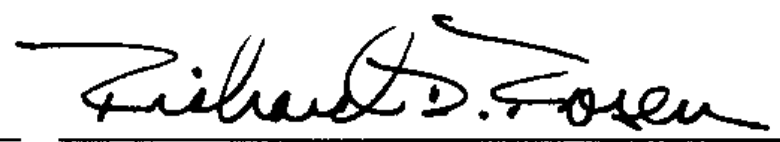

RICHARD D. ROSEN

$\mathrm{COL}, \mathrm{JA}$

Staff Judge Advocate

Natural
Branch

Directorate of Public Works

APPROVED BY:

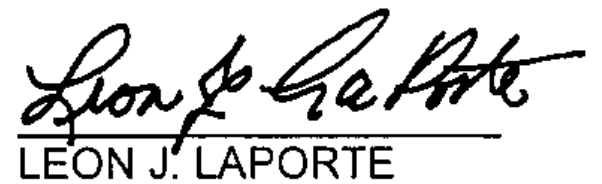

Lieutenant General, USA

Commanding 
Environmental Assessment of the proposed "Endangered Species Management Plan for Fort Hood, Texas; FY01-05"

$\begin{array}{ll}\text { Prepared by: } & \text { Directorate of Public Works } \\ & \text { Environmental Division } \\ & \text { III Corps and Fort Hood } \\ & \text { 4612 Engineer Drive Room } 76 \\ & \text { Fort Hood TX 76544-5028 }\end{array}$

\section{INTRODUCTION}

\section{Background}

This environmental assessment provides an analysis of the environmental, cultural, and socioeconomic effects of implementation of the proposed "Endangered Species Management Plan (ESMP) for Fort Hood, Texas; FY01-05." The proposed action is an initiative of Fort Hood to meet requirements of Army Regulation (AR) 200-3 (Chapter 11) and Section 7 of the Endangered Species Act of 1973, as amended. This environmental assessment is provided in compliance with the National Environmental Policy Act.

Two alternatives are considered in this environmental assessment including (1) continued operation under the USFWS September 1993 biological opinion for Fort Hood, and (2) the Army's preferred alternative of implementing the proposed installation ESMP. The first alternative is the "No Action" alternative, which provides the baseline for assessing cumulative effects on the human environment of Fort Hood's preferred alternative.

A biological assessment of this proposed action has been submitted to the U.S. Fish and Wildlife Service (USFWS) in compliance with Section 7 requirements of the ESA. USFWS has reviewed and approved language in this draft ESMP, and issued a final biological opinion on 26 July 2000 stipulating that, in order to avoid further consultation, the ESMP must be finalized and in effect within 90 days. The biological assessment and Biological Opinion are included in this analysis by reference where applicable.

\section{Need for the Proposed Action}

The proposed action is implementation of the "Endangered Species Management Plan (ESMP) for Fort Hood, Texas; FY01-05." AR 200-3, Chapter 11 requires Army installations to develop endangered species management plans with a 5-year term of implementation. Key elements of this Army requirement are that installation ESMP's (1) must support USFWS conscrvation and recovery objectives for listed populations occurring on installation lands, and (2) must provide adequate flexibility for accomplishment of military mission-essential tasks.

The Army and Fort Hood have the dual responsibility to maintain readiness of soldiers to fight and win conflicts on terms favorable to the United States and its allies, as well as to 
comply with environmental regulations through stewardship of lands under the Army's management. Development of installation ESMPs is the mechanism to achieve balance between the Army's primary readiness mission and environmental stewardship for threatened or endangered species.

\section{Scope}

The scope of this environmental assessment is limited to assessing the environmental, cultural, and socioeconomic effects on Fort Hood resulting from implementing the proposed installation ESMP. No other Federal or private lands will be subject to conditions of implementing the proposed Fort Hood ESMP.

\section{ESMP Development and Public Involvement}

Endangered species surveys, research and monitoring on Fort Hood were initiated in 1987 concurrent with listing of the black-capped vireo (Vireo atricapillus) as endangered in October 1987 (52FR 37420-37423). These efforts were augmented to include the golden-cheeked warbler (Dendroica chrysoparia) in 1991 after this species was listed in December 1990 (55 FR 53153-53160). As a result of listing these two species and because Fort Hood supported significant populations of both species, the installation implemented "Endangered Species Training Guidelines" effective 1 June 1990 to avoid actions that might result in adverse effects on endangered warblers, vireos and other sensitive resources.

In December 1992, Fort Hood completed a biological assessment (Tazik et al. 1992) of its ongoing mission activities. A total of 24 independent experts were consulted in preparation of the 1992 biological assessment. In response to this assessment, the USFWS issued a biological opinion dated September 1993 that established reasonable and prudent measures to allow continuation of the military mission, which included continued implementation of the Fort Hood Endangered Species Training Guidelines. The 1993 biological opinion also established thresholds for allowable take for endangered warblers and vireos on the installation.

By the end of the calendar year 1995, Fort Hood had completed a first draft of an installation ESMP in compliance with AR 200-3. This draft ESMP incorporated conditions of the 1993 USFWS biological opinion and current status and conditions for listed species on the installation. However, this draft ESMP was superseded by major uncontrolled fires in February 1996 that destroyed extensive areas of endangered warbler and vireo habitats well in excess of allowable incidental take under the 1993 biological opinion.

In response to the February 1996 fires, Fort Hood immediately entered into Section 7 consultation with the USFWS. As a result of the changed habitat and population status for warblers and vireos and subsequent consultations with the USFWS, Fort Hood drafted the current proposed installation ESMP. 


\section{AFFECTED ENVIRONMENT}

A description of Fort Hood and installation land use activities is provided in Chapter 2 of the proposed ESMP and is included in this environmental assessment by reference. Chapter 2 of the ESMP describes the known landscape and habitat attributes of Fort Hood, military training activities, and other non-military land use activities.

\section{ALTERNATIVES}

Alternatives to the proposed action were developed from meetings and correspondence among representatives of Fort Hood, Army Forces Command, U.S. Army Construction Engineering Research Laboratories, and USFWS. Results of this scoping process resulted in three alternatives. These alternatives considered in detail include (1) continued operation under the USFWS September 1993 biological opinion for Fort Hood, (2) the Army's preferred alternative of implementing the proposed installation ESMP, and (3) implementing the proposed ESMP with alternative modifications to specific conservation actions.

Alternative 2, implementation of the proposed ESMP, is Fort Hood's preferred alternative. The proposed ESMP is included in this environmental assessment by reference. Alternative 1, continued operation under the USFWS September 1993 biological opinion, is the "no action" altemative and provides the baseline for assessing effects of the preferred alternative.

Alternative 1 (no action): Continue operation under the USFWS September 1993 biological opinion for Fort Hood. Alternative 1 does not adequately address necessary conservation actions and current conditions resulting from the February 1996 fires on Fort Hood. Continued operations under alternative 1 also do not explicitly define population/habitat objectives consistent with published USFWS recovery objectives for listed species occurring on Fort Hood. The "no action" alternative also does not adequately integrate military mission requirements on Fort Hood in the context of established population goals. Continued operation under the 1993 biological opinion will not meet compliance requirements under Section 7 of the ESA or AR 200-3, will not adequately prevent future occurrence of catastrophic events such as the February 1996 fires, and will potentially compromise the Army's mission to adequately train and prepare troops on Fort Hood.

Alternative 2 (preferred alternative): Implement proposed "Endangered Species Management Plan for Fort Hood, Texas; FY01-05." Key features of the proposed ESMP representing changes from the baseline "no action" alternative would:

- Explicitly establish population/habitat goals for Fort Hood consistent with USFWS recovery objectives.

- Implement improved fire response, prevention and management on the installation and assess effects of previous fires on the installation. 
- Reduce training restrictions in some endangered species habitats consistent with established population/habitat goals.

- Provide increased flexibility for accomplishment of the military mission consistent with established population/habitat goals.

Alternative 3: Alternative actions considered for implementation under the preferred alternative (Implement Proposed ESMP). The proposed ESMP when implemented will initiate or continue several specific conservation, management and protection activities. Alternatives were considered for several of these actions and are detailed below. Rejected alternatives are described below, and the reasons for rejecting these alternatives are outlined. Rejected alternatives are not considered further under the analysis of effects. The preferred alternative for each activity is also described below and effect of implementing the preferred alternative for each is further evaluated in Section 4 of this assessment.

\section{Reduce Nest Parasitism by Brown-headed Cowbirds}

Preferred alternative: Implement a year-round trapping effort and shooting during the nesting season to remove breeding female cowbirds in the Fort Hood population. This is the current control program implemented on Fort Hood and has been well documented as effectively reducing cowbird parasitism of blackcapped vireo nests.

\section{Alternative a: Discontinue cattle grazing in or near nesting habitat.} Currently, grazing is conducted under a negotiated lease agreement with the Central Texas Cattlemen's Association. To ensure effectiveness, this alternative would require extensive modification of existing lease or grazing deferment.

Alternative b: Conduct trapping only during nesting season. The preferred alternative implements year-round trapping with reduced trapping effort during the non-breeding season. Year-round trapping ensures a continuously available decoy stock of live cowbirds and continuity of trapping personnel. Limiting trapping to the nesting season would cause difficulties in obtaining decoy cowbirds in numbers sufficient for the relatively large scale trapping effort during the breeding season and would require rehiring and training of trapping personnel on an annual basis.

Alternative c: Implement non-lethal control methods. Non-lethal methods of cowbird control (i.e. contraceptive methods) were considered but were rejected because available methods are not well-proven, are cost-prohibitive, and for some applications could not ensure that non-target species would not be affected.

\section{Population Monitoring Activities}

Preferred Alternative: Implement banding and nest monitoring activities. Under the preferred alternative adults, nestlings and juveniles will be banded to 
assess adult and first-year survival and dispersal. Nest visits will be conducted to evaluate levels of nest parasitism, depredation, and productivity. These data are necessary to evaluate effectiveness of management and protection policies and to refine and validate population models on which installation population goals are based.

Alternative a: No banding. Under this alternative, nest visits would be conducted but there would be no direct handling of birds for the purpose of banding individuals. This alternative is not preferred because banding is necessary to document adult turnover and juvenal survival and dispersal. Population models are sensitive to these parameter estimates. Refinement and validation of these parameter estimates are necessary to increase confidence in predictive models used to establish population thresholds and evaluate population change.

Alternative b: No banding and no nest visits. The no banding alternative is not preferred for the reasons noted above. Nest visits are required to adequately document fledging success and nest parasitism. These data are necessary to assess success of cowbird control programs and to validate reproductive parameter estimates for evaluating of population change. Dependence on observation of adults with juvenals post-fledging does not adequately characterize reproductive potential and outcomes in the population.

\section{Training Restrictions}

Preferred alternative: Lift training restrictions in designated areas. Designation of training restriction status in habitats represents the best consensus of installation natural resource managers and trainers to meet conservation objectives for endangered species and also allow mission-critical training activities to be performed. Protected areas represent the habitat areas on Fort Hood necessary to meet endangered species conservation objectives.

Alternative a: Redesignate training restriction status for alternative habitat areas. Several alternative distributions of training restricted versus non-restricted habitats were considered in development of the ESMP. However, training restriction status in habitats designated in the ESMP represents the best consensus solution to achieve habitat conservation objectives, training flexibility, and compliance of soldiers conducting field training.

\section{ENVIRONMENTAL, CULTURAL AND SOCIOECONOMIC EFFECTS}

This section discloses anticipated environmental, cultural and socioeconomic effects anticipated from implementation of the proposed Fort Hood ESMP. Alternative 1 (no action) provides the baseline for assessing effects of implementation of the preferred alternative. 
Environmental, cultural and socioeconomic values considered in this assessment include:

- Biological

- Threatened or endangered species

- Habitat quality

- Biodiversity

- Physical Environment

- Air quality

- Soils

- Water quality

- Cultural Resources

- Native American

- Historic preservation

- Socioeconomic

- Recreation

- Noise

- Economic

\section{Biological Resources}

\section{Threatened or endangered species}

The Fort Hood ESMP and companion biological assessment disclose anticipated effects of the preferred alternative on endangered species on Fort Hood, Texas. These analyses of anticipated effects are incorporated here by reference.

Invasive monitoring activities (i.e. banding of juveniles and adults, nest checks, and human observation) represent no change from the current baseline activity.

Methodologies are implemented to minimize to the extent possible any detrimental effects of these biological monitoring activities. All applicable permits are obtained for these activities and current methods are approved by permitting agencies.

In summary, the biological assessment of the proposed ESMP concludes that implementation will not adversely affect populations of endangered species on Fort Hood and will assist conservation and recovery of listed species on the installation. 
Habitat protection measures and enhanced fire protection and management policies implemented under the proposed ESMP will assist in maintaining the high level of habitat quality and biodiversity currently found on Fort Hood. No adverse impacts on habitat quality or biodiversity are anticipated under the preferred alternative.

Cowbird control activities under the proposed ESMP represent no change from the baseline condition. Control activities destroy brown-headed cowbird individuals by trapping and shooting. All applicable permits are obtained for these activities and current methods are reviewed by veterinary authorities and approved by permitting agencies as humane. Cowbird control efforts on Fort Hood result in reduction of local abundance of this species and have no range-wide impact. Current trapping methodologies greatly minimize incidence of capture of non-target species.

Habitat fragmentation from firebreak construction will be negligible due to use of existing roads and trails and natural habitat breaks and transitions.

Physical Environment: Air quality, Soils, Water quality

No activities prescribed in the proposed ESMP are anticipated to adversely affect air quality, soils or water quality. Measures to protect habitats in the vicinity of karst features on the installation may assist in maintaining ground water quality on the installation. Maintenance of endangered species habitats will assist in stabilizing soils and maintaining water quality. Future construction of firebreaks on the installation may result in limited soil disturbance; however, maintenance of herbaceous cover on these firebreaks will minimize erosion potential.

\section{Cultural Resources}

All ground clearing activities associated with construction of firebreaks and other habitat management goals, will be reviewed under Fort Hood Regulation 420-2 as per Fort Hood's Cultural Resource Management Plan FY95-99, proposed Cultural Resource Management Plan FY00-04, and associated Standard Operating Procedures.

Concurrence or Non-concurrence will be recorded on the Coordination for Land Excavation Form $420-\mathrm{X} 10$ by Fort Hood's Cultural Resources Staff to avoid potential impacts on eligible or potentially eligible National Register of Historic Places Cultural Resources. These resources include but are not limited to Native American and Historic resources under Fort Hood Stewardship. Adherence to this procedure will result in No Adverse Effects to known cultural resources for projects encompassed in this EA.

\section{Socioeconomic}

\section{Recreation}

Restrictions on off-road recreational activities in endangered species habitats under the proposed ESMP represent no change from the current baseline restrictions. Research is 
prescribed under the proposed ESMP to evaluate effects of disturbance to endangered golden-cheeked warbler due to recreational off-road bicycles. Results from this research may result in future modification to current restrictions in endangered spccies habitats.

\section{Construction}

No commercial construction is conducted on Fort Hood lands subject to conditions of the proposed ESMP so no adverse impacts are anticipated. Restrictions in the proposed ESMP on military construction in endangered species habitats remains unchanged from current baseline restriction. Military construction will require Section 7 consultation with the USFWS.

Noise

No cumulative increase in noise sources are anticipated under the proposed ESMP.

\section{Economic}

No commercial development, crop agricultural or commercial forestry are conducted on lands subject to the ESMP so no adverse economic impacts are anticipated. Current grazing leases remain unchanged under the proposed ESMP.

\section{CUMULATIVE EFFECTS AND CONCLUSION}

No significant cumulative adverse effects on biological, cultural or socioeconomic resources are anticipated from implementation of the preferred alternative.

Implementation of the preferred alternative will maintain progressive biological management of endangered species' on Fort Hood while maintaining the Army's ability to effectively train. Additional monitoring, research, and mitigation requirements under the proposed ESMP will provide mechanisms to recognize, evaluate, and rectify any adverse effects before cumulative, irreversible impacts occur.

Fort Hood lands currently support significant populations of endangered black-capped vireos and golden-cheeked warblers as well as other sensitive and rare biological resources. Achieving recovery objectives under the proposed ESMP will be a significant step toward supporting regional recovery objectives for these endangered species. Achieving these objectives will provide Fort Hood the greatest flexibility in achieving its military mission in compliance with regulatory requirements under the Endangered Species Act and the National Environmental Policy Act. 


\section{CERL Distribution}

Chief of Engineers

ATTN: CEHEC-IM-LH (2)

Engineer Research and Development Center (Libraries)

ATTN: ERDC, Vicksburg, MS

ATTN: Cold Regions Research, Hanover, NH

ATTN: Topographic Engineering Center, Alexandria, VA

Fort Hood Nat Res Branch (50)

Defense Tech Info Center 22304

ATTN: DTIC-O

56

$5 / 00$ 


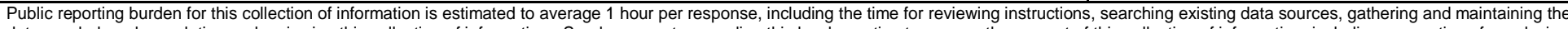

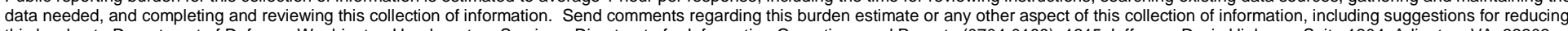

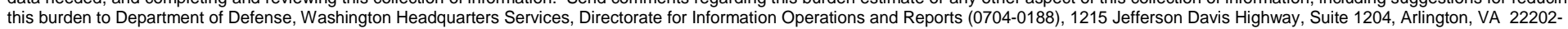

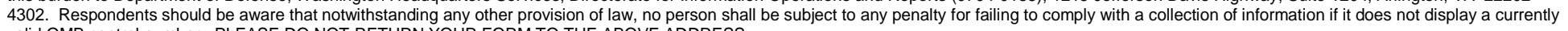
valid OMB control number. PLEASE DO NOT RETURN YOUR FORM TO THE ABOVE ADDRESS.
1. REPORT DATE (DD-MM-YYYY)
03-2001
2. REPORT TYPE
Final
3. DATES COVERED (From - To)

4. TITLE AND SUBTITLE

$01-05$

Endangered Species Management Plan for Fort Hood, Texas; FY01-05

5a. CONTRACT NUMBER

5b. GRANT NUMBER

5c. PROGRAM ELEMENT NUMBER

6. AUTHOR(S)

Timothy J. Hayden, John D. Cornelius, Howard J. Weinberg, Leslie L. Jette, and Robert H. Melton

\section{5d. PROJECT NUMBER}

MIPR

5e. TASK NUMBER

5f. WORK UNIT NUMBER

9DCER00242

7. PERFORMING ORGANIZATION NAME(S) AND ADDRESS(ES)

U.S. Army Engineer Research and Development Center (ERDC)

Construction Engineering Research Laboratory (CERL)

P.O. Box 9005

Champaign, IL 61826-9005

\section{SPONSORING / MONITORING AGENCY NAME(S) AND ADDRESS(ES)}

III Corps and Fort Hood

Natural Resources Branch

Bldg 1939

Fort Hood, TX 76544

\section{DISTRIBUTION / AVAILABILITY STATEMENT}

Approved for public release; distribution is unlimited.

\section{SUPPLEMENTARY NOTES}

Copies are available from the National Technical Information Service, 5285 Port Royal Road, Springfield, VA 22161.

\section{ABSTRACT}

Fort Hood Military Reservation is an 87,890 ha U.S. Army installation located in central Texas, providing training facilities for the full range of mission requirements including maneuver exercises for units up to brigade level, firing of live weapons, and aviation training.

The presence of Federally listed endangered species on Fort Hood is a significant natural resource management challenge for the Army and Fort Hood. In accordance with the Endangered Species Act of 1973, as amended, the Army must assist recovery of all listed threatened and endangered (T\&E) species and their habitats under the installation's management authority. Army Regulation (AR) 200-3 requires installations to prepare an Endangered Species Management Plan (ESMP) for all listed and proposed T\&E species. This plan should be used as a tool to achieve conservation objectives for populations of listed and proposed T\&E species and to minimize impacts on the training mission. The U.S. Fish and Wildlife Service Biological Opinion for Fort Hood (September 1993, as amended) provides requirements and guidance for endangered species management on Fort Hood.

The objective of this ESMP is to provide a comprehensive plan for maintaining and enhancing populations and habitats of federally listed and candidate species on Fort Hood while maintaining mission readiness consistent with Army and Federal environmental regulations.

\section{SUBJECT TERMS}

natural resource management, military training, environmental management, threatened and endangered (T\&E) species, endangered species management plan (ESMP)

\begin{tabular}{|c|c|c|c|c|c|}
\hline 16. SECURITY CL & IFICATION OF: & & $\begin{array}{l}\text { 17. LIMITATION } \\
\text { OF ABSTRACT }\end{array}$ & $\begin{array}{l}\text { 18. NUMBER } \\
\text { OF PAGES }\end{array}$ & $\begin{array}{c}\text { 19a. NAME OF RESPONSIBLE PERSON } \\
\text { Timothy J. Hayden }\end{array}$ \\
\hline $\begin{array}{l}\text { a. REPORT } \\
\text { Unclassified }\end{array}$ & $\begin{array}{l}\text { b. ABSTRACT } \\
\text { Unclassified }\end{array}$ & $\begin{array}{l}\text { c. THIS PAGE } \\
\text { Unclassified }\end{array}$ & SAR & 166 & $\begin{array}{l}\text { 19b. TELEPHONE NUMBER (in- } \\
\text { clude area code) } \\
\text { (217) } 352-6511 \text { ext } 6365\end{array}$ \\
\hline
\end{tabular}

